EVALUATION OF VISUAL CUES OF THREE DIMENSIONAL VIRTUAL ENVIRONMENTS FOR HELICOPTER SIMULATORS

\author{
A THESIS SUBMITTED TO \\ THE GRADUATE SCHOOL OF INFORMATICS \\ OF \\ THE MIDDLE EAST TECHNICAL UNIVERSITY
}

BY

YASEMIN ÇETIN

IN PARTIAL FULFILLMENT OF THE REQUIREMENTS FOR THE DEGREE OF MASTER OF SCIENCE

IN

THE DEPARTMENT OF INFORMATION SYSTEMS

SEPTEMBER 2008 
Approval of the Graduate School of Informatics

Prof. Dr. Nazife BAYKAL

Director

I certify that this thesis satisfies all the requirements as a thesis for the degree of Master of Science.

Prof. Dr. Yasemin YARDIMCI ÇETIN

Head of Department

This is to certify that we have read this thesis and that in our opinion it is fully adequate, in scope and quality, as a thesis for the degree of Master of Science.

Prof. Dr. Yasemin YARDIMCI ÇETIN Supervisor

Examining Committee Members

Assoc. Prof. Dr. Veysi işLER

(METU, CENG)

Prof. Dr. Yasemin YARDIMCI ÇETIN

(METU, II)

Assoc. Prof. Dr. Kürşat ÇAĞILTAY

(METU, CEIT)

Dr. Altan KOÇYiĞiT

(METU, II)

Dr. Sevgi ÖZKAN

(METU, II) 
I hereby declare that all information in this document has been obtained and presented in accordance with academic rules and ethical conduct. I also declare that, as required by these rules and conduct, I have fully cited and referenced all material and results that are not original to this work.

Name, Last Name: Yasemin ÇETiN

Signature: 


\title{
EVALUATION OF VISUAL CUES OF THREE DIMENSIONAL VIRTUAL ENVIRONMENTS FOR HELICOPTER SIMULATORS
}

\author{
ÇETIN, Yasemin \\ M.Sc., Department of Information Systems \\ Supervisor: Prof. Dr. Yasemin Yardımcı Çetin
}

September 2008, 105 pages

Flight simulators are widely used by the military, civil and commercial aviation. Visual cues
are an essential part of helicopter flight. The required cues for hover are especially large
due to closeness to the ground and small movements.

In this thesis, density and height parameters of the 3D (Three Dimensional) objects in the scene are analyzed to find their effect on hovering and low altitude flight. An experiment is conducted using a PC-based flight simulator with three LCD monitors and flight control set. Ten professional military pilots participated in the experiment. 
Results revealed that object density and object height are effective on the horizontal and vertical hovering performance. There is a peak point after which increasing the density does not improve the performance. In low altitude flight, altitude control is positively affected by smaller object height. However, pilots prefer the scenes composed of the high and mixture objects while hovering and flying at low altitude. Distance estimation is affected by the interaction of the object density and height.

Keywords: Flight Simulator, Visual Cue, Hover, Low Altitude Flight, 3D Object 


\title{
Öz
}

\section{ÜÇ BOYUTLU SANAL ÇEVRE GÖRSEL IPUÇLARININ HELIKOPTER SIMÜLATÖRLERI AÇISINDAN INCELENMESI}

\author{
ÇETIN, Yasemin \\ Yüksek Lisans, Bilişim Sistemleri Bölümü \\ Tez Yöneticisi: Prof. Dr. Yasemin Yardımcı Çetin
}

Eylül 2008, 105 sayfa

Uçuş simülatörleri askeri, sivil ve ticari havacılık tarafından yaygın olarak kullanılmaktadır. Görsel ipuçları helikopter uçuşlarının en temel parçasıdır. Havır için gerekli ipuçları yere yakınlık ve küçük hareketlerden dolayı oldukça fazladır.

Bu tezde sahnedeki 3B( Üç Boyutlu) nesnelerin yoğunluk ve yükseklik parametreleri, havır ve alçak irtifa uçuşuna olan etkilerini bulmak için analiz edilmiştir. Üç LCD ekran ve uçuş kontrol setine sahip PC-tabanlı bir simülatör kullanılarak deney yapılmıştır. On profesyonel askeri pilot deneye katılmıştır. 
Sonuçlar göstermektedir ki nesne yoğunluğu ve nesne yüksekliği düşey ve yatay havır performansını etkilemektedir. Bir tepe noktası bulunmakta bu noktadan sonra nesne yoğunluğunun arttırılması performansı geliştirmemektedir. Alçak irtifa uçuşunda irtifa kontrolü küçük nesnelerden pozitif olarak etkilenmektedir. Fakat pilotlar havır ve alçak iritifa uçuşu yaparken büyük ve karışık nesnelerden oluşan sahneleri tercih etmektedir. Mesafe tahmini nesne yoğunluğu ve nesne yüksekliğinin etkileşiminden etkilenmektedir.

Anahtar Kelimeler: Uçuş Simülatörü, Görsel İpucu, Havır, Alçak İrtifa Uçuşu, 3B Nesne 
To my mother 


\section{ACKNOWLEDGMENTS}

I wish to offer my sincere thanks and appreciation to my supervisor Prof. Dr. Yasemin Yardımcı Çetin for her precious help, invaluable suggestions, continuous support, guidance, criticisms, encouragements and patience throughout this study.

I would like to also express my special gratitude to Erdal Yılmaz for his support and suggestions throughout my research.

I am very grateful to Hüseyin Levent İpek and Cüneyt Karaahmetoğlu for their support during the system test and calibration.

My special thanks are due to staff of Kara Havacılık Okul Komutanlığı for their hospitality and helps.

I would also like to thank my friends Habil Kalkan, Selda Eren, Özden Özcan Top, Rahime Belen and Berna Bakır for their friendship and encouragement.

I appreciate Ayşe Ceylan, Sibel Gülnar, Necla Işıklar and Ali Kantar in the institute for their kindness since the beginning of my M.Sc. study.

I will never forget the support of my housemate Buket Bezgin and her fiancé Serdar Çarbaş.

I would also like to thank to TUBITAK-BIDEB for financial support during my M.Sc education.

Finally, I would like to express my deepest gratitude to my parents and my brother for their love, encouragement, and support throughout my education. 


\section{TABLE OF CONTENTS}

ABSTRACT

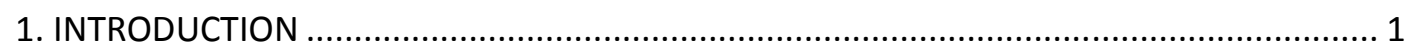

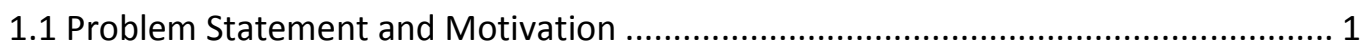

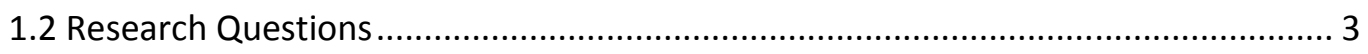

1.3 Organization of Thesis ..................................................................................... 3

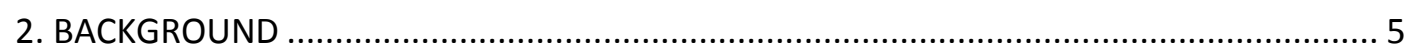

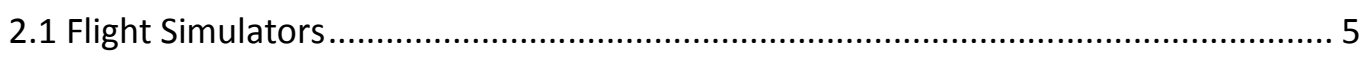

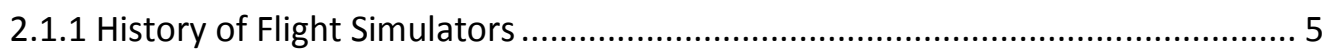

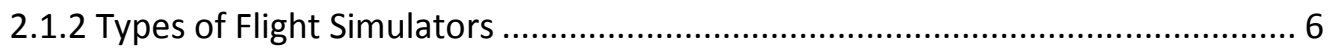

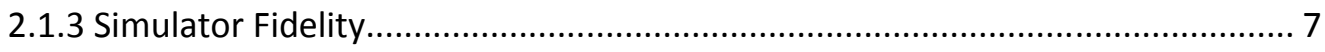




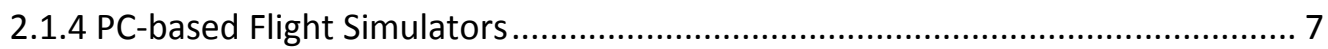

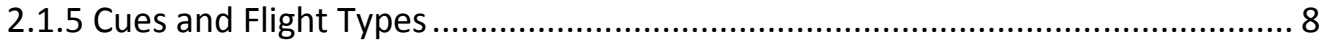

2.1.6 3D Objects and Distance Perception ........................................................... 9

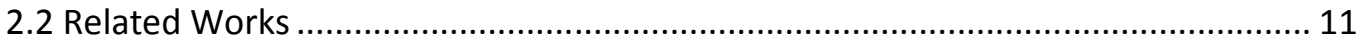

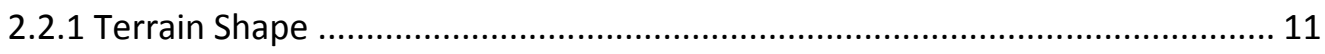

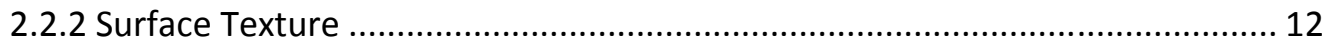

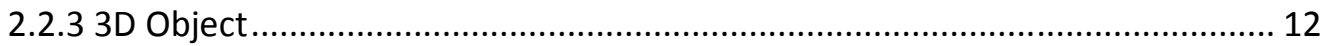

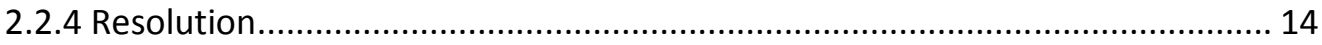

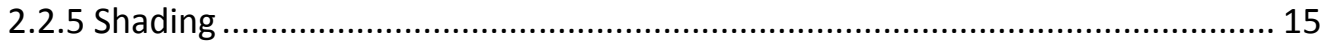

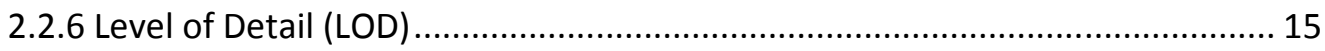

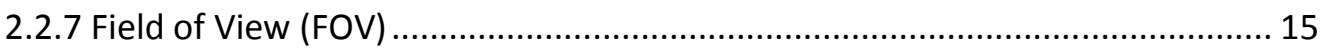

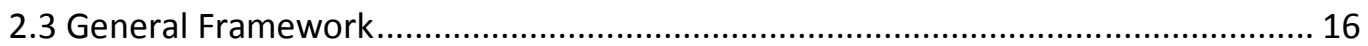

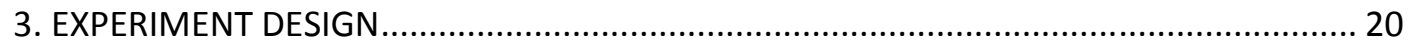

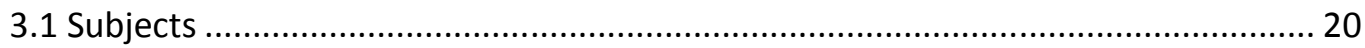

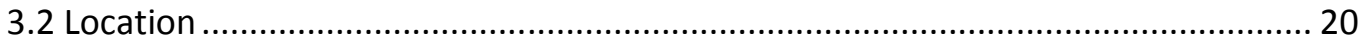

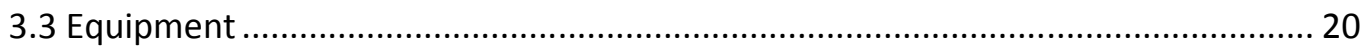

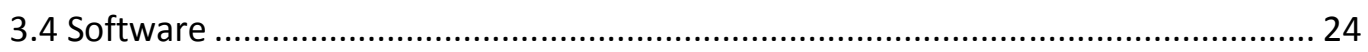

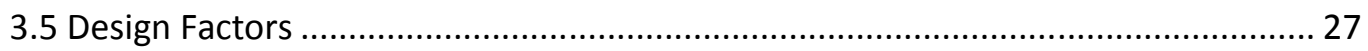

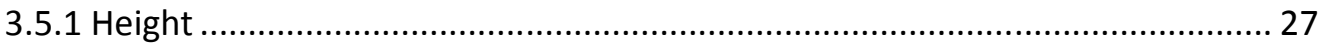

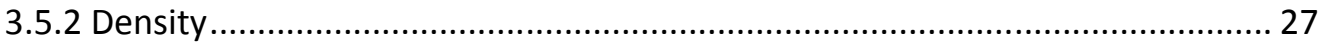

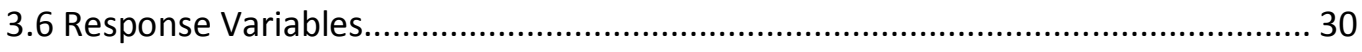

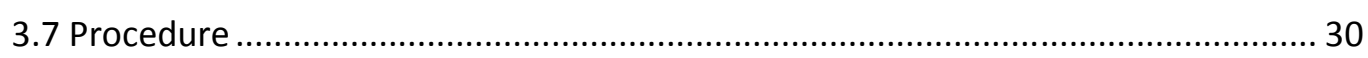

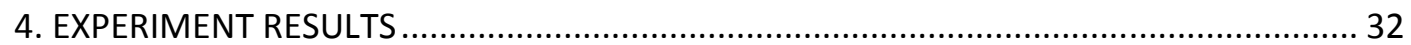

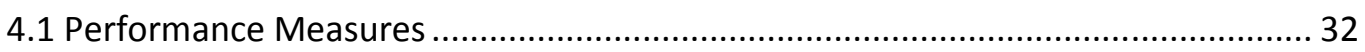

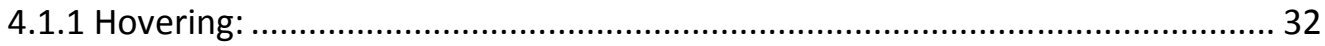




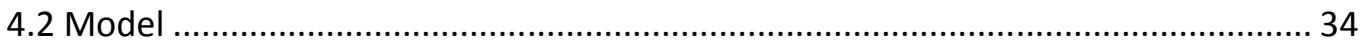

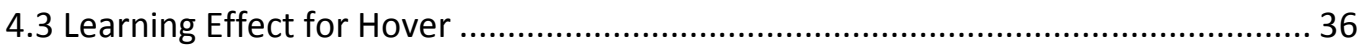

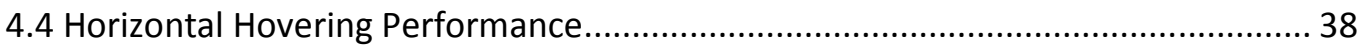

4.4.1 Model Adequacy: ............................................................................. 38

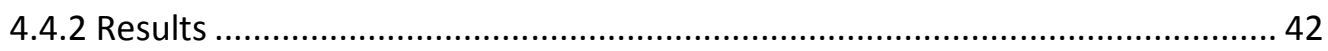

4.5 Vertical Hovering Performance ................................................................. 45

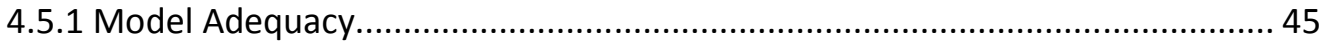

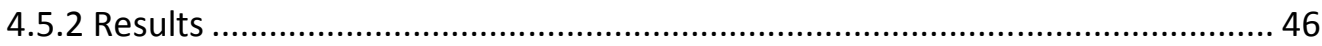

4.6 Learning Effect for Low Altitude Flight..................................................... 49

4.7 Horizontal Low Altitude Flight Performance ................................................ 51

4.7.1 Model Adequacy........................................................................... 51

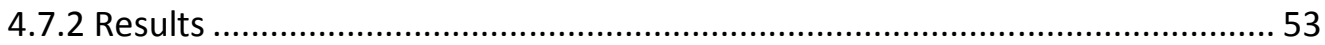

4.8 Vertical Low Altitude Flight Performance ..................................................... 57

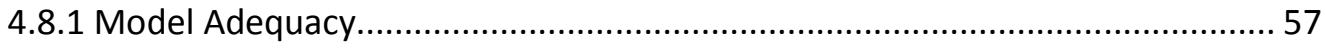

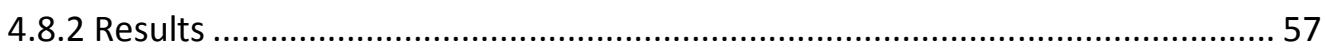

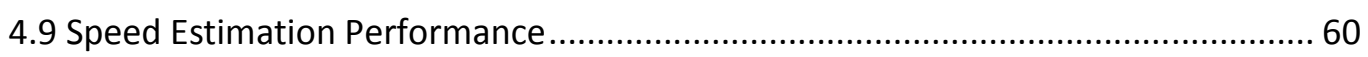

4.9.1 Model Adequacy............................................................................... 60

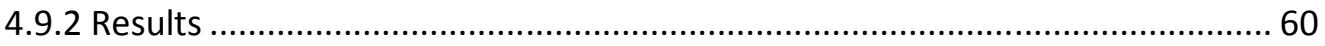

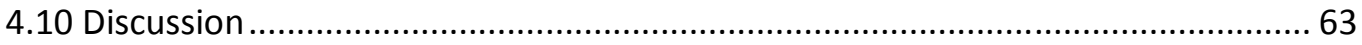

4.11 Questionnaire Results .................................................................... 63

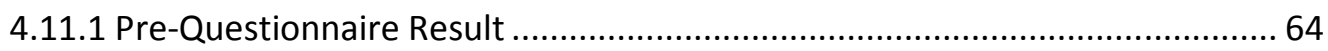

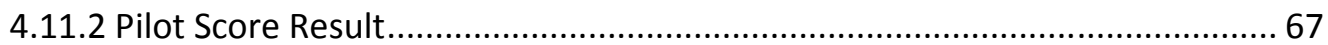

4.11.3 Post-Questionnaire Result.......................................................... 70

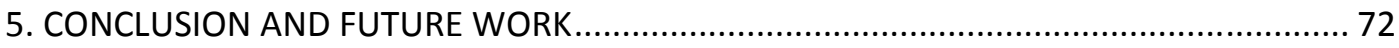




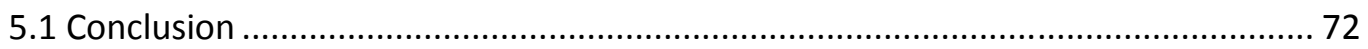

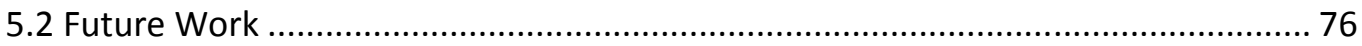

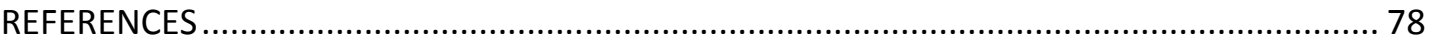

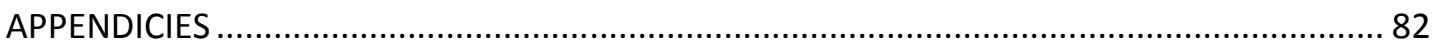

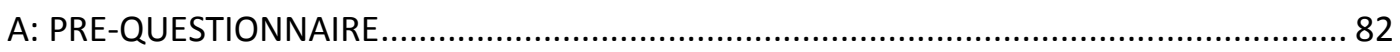

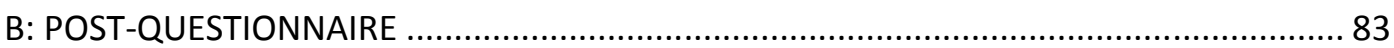

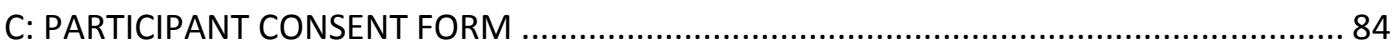

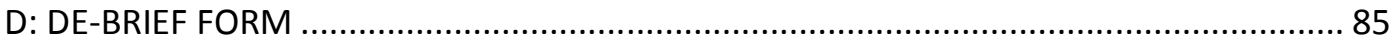

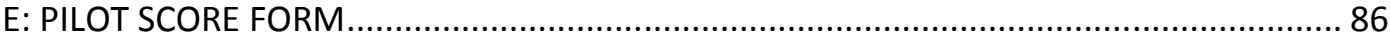

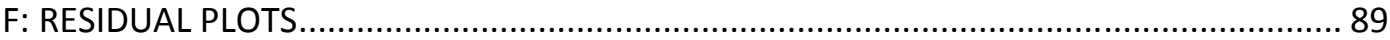

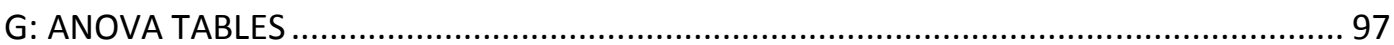

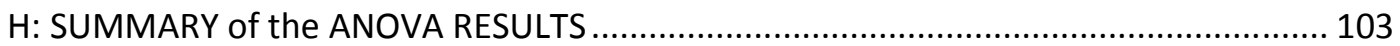




\section{LIST OF TABLES}

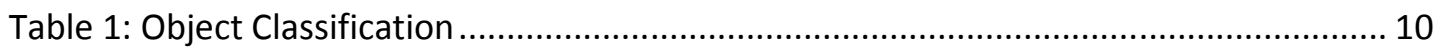

Table 2 Used Equipment of Previous Research ................................................................ 21

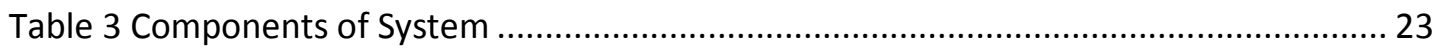

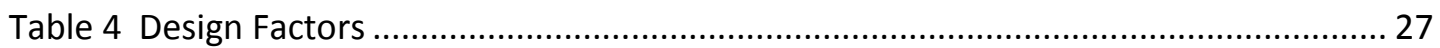

Table 5 Response Variables ....................................................................................... 30

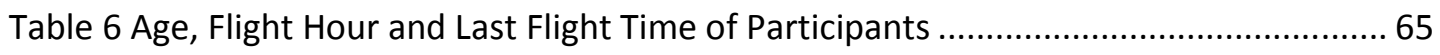

Table 7 Correlation Coefficient of Flight Hours with Performance ....................................... 66

Table 8 Correlation of Simulator Usage and Performance ..................................................... 66

Table 9 Most Frequently Used Flight Helicopter Type ...........................................................6 66

Table 10 Pilot Marks for Ability to Stabilize the Helicopter..................................................... 71

Table 11 Summary of the DT and AT Performances for Hover............................................ 73

Table 12 Summary of the DEE and AT Performances for Low Altitude Flight ....................... 73

Table 13 Summary of the Correlation Analysis Between Performace and Experience......... 73

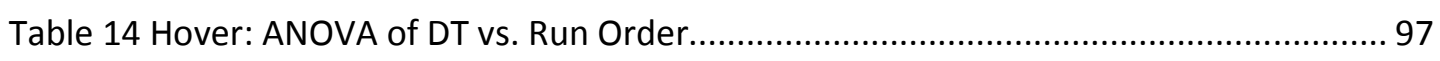

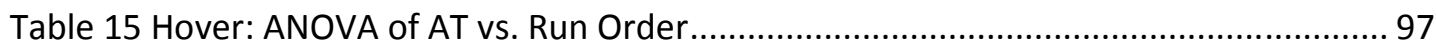

Table 16 Hover: ANOVA of LOG DT vs. Object Density, Object Size, Block No (Subject)....... 97

Table 17 Hover: ANOVA of LOG DT vs. Object Density, Object Size, Block No (Subject)....... 98

Table 18 Hover: ANOVA of LOG AT vs. Object Density, Object Size, Block No (Subject)....... 98

Table 19 Hover: ANOVA of LOG AT vs. Object Density, Object Size, Block No (Subject)....... 98

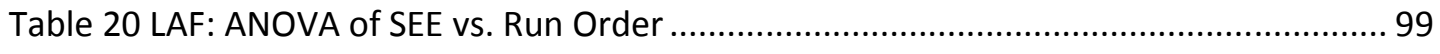

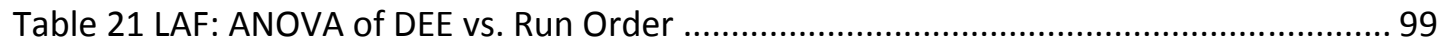

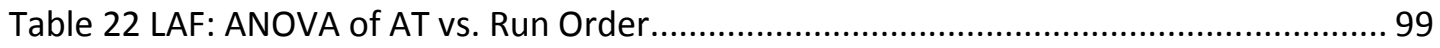


Table 23 LAF: Two-way ANOVA: AT versus run order; block (without first run) .....

Table 24 LAF: ANOVA of SQRT DEE vs. Object Density, Object Size, Block No (Subject)..... 100

Table 25 LAF: ANOVA of SQRT DEE vs. Object Density, Object Size, Block No (Subject)..... 100

Table 26 LAF: ANOVA of LOG AT vs. Object Density, Object Size, Block No (Subject)........ 100

Table 27 LAF: ANOVA of LOG AT vs. Object Density, Object Size, Block No (Subject)......... 101

Table 28 LAF: ANOVA of SEE vs. Object Density, Object Size, Block No (Subject) .............. 101

Table 29 LAF: ANOVA of SEE vs. Object Density, Object Size, Block No (Subject) ............. 101

Table 30 Hover: ANOVA of SCORE vs. Object Density, Object Size, Block No (Subject) ...... 102

Table 31 LAF: ANOVA of SCORE vs. Object Density, Object Size, Block No (Subject) .......... 102

Table 32 Summary of the ANOVA Results for Score and Learning Effect........................ 103

Table 33 Summary of the ANOVA Results for the DT $\left(4^{*} 3\right)$, AT(4*3) and SEE(4*3) ......... 104

Table 34 Summary of the ANOVA Results for the DT(4*4), AT(4*4) and SEE(4*4) .......... 105 


\section{LIST OF FIGURES}

Figure 1: Subject Groups and Scene Presentation (Option1) .............................................. 17

Figure 2: Subject Groups and Scene Presentation (Option2) ............................................. 18

Figure 3: Subject Groups and Scene Presentation (Option3) ............................................ 19

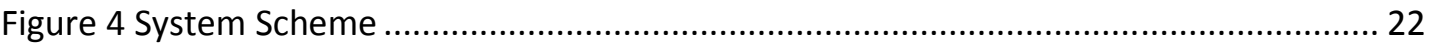

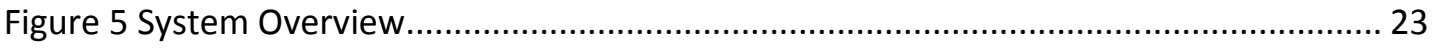

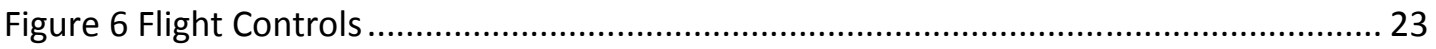

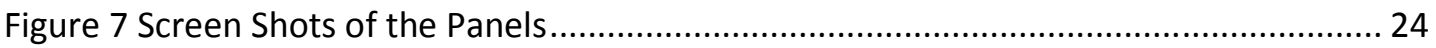

Figure 8 Screen Shot of Data Input \& Output Tool .............................................................. 25

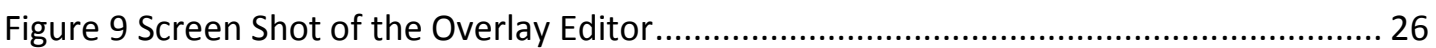

Figure 10 Levels of Object Height for 144 objects per $\mathrm{km}^{2}$................................................ 28

Figure 11 Levels of Object Density for $5 \mathrm{~m}$ height objects .................................................. 29

Figure 12 Calculation of Distance Traveled (DT) for Hover.................................................. 33

Figure 13 Calculation of Altitude Traveled (AT) for Hover.................................................. 34

Figure 14 Hover: Main Effects of Run Order (With in Subjects) on DT ................................. 37

Figure 15 Hover: Main Effects of Run Order (With in Subjects) on AT ................................ 37

Figure 16 Hover: Normal Probability Plot of Residuals for DT (4 Object Density *3 Object Size) 39

Figure 17 Hover: Residuals versus the Order of the Data for DT (4 Object Density *3 Object Size) 40

Figure 18 Hover: Residuals versus the Fitted Values for DT (4 Object Density *3 Object Size)

Figure 19 Hover: Residual Plots for LOG DT (4 Object Density *3 Object Size) 41 
Figure 20 Hover: Main Effects Plot for LOG DT versus Object Height (3 levels), Object Density (4 levels)

Figure 21 Hover: Interaction Plot for LOG DT versus Object Height (3 levels), Object Density (4 levels).

Figure 22 Hover: Main Effects Plot for LOG DT versus Object Height (4 levels), Object Density (4 levels)

Figure 23 Hover: Interaction Effects Plot for LOG DT versus Object Height (4 levels), Object Density (4 levels)

Figure 24 Hover: Main Effects Plot for LOG AT versus Object Height (3 levels), Object Density (4 levels) 47

Figure 25 Hover: Interaction Plot for LOG AT versus Object Height (3 levels), Object Density (4 levels). 47

Figure 26 Hover: Main Effects Plot for LOG AT versus Object Height (4 levels), Object Density (4 levels). 48

Figure 27 Hover: Interaction Plot for LOG AT versus Object Height (4 levels), Object Density (4 levels) 49

Figure 28 LAF: Main Effects of Run Order (With in Subjects) on SEE .................................. 50

Figure 29 LAF: Main Effect of Run Order (Within Subjects) on DEE .................................... 50

Figure 30 LAF: Main Effect of Run Order (Within Subjects) on AT ...................................... 52

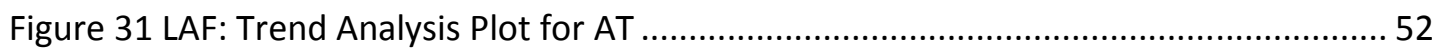

Figure 32 LAF: Trend Analysis Plot for AT without First Runs .............................................. 53

Figure 33 Hover: Main Effects Plot for SQRT DEE versus Object Height (3 levels), Object Density (4 levels) 55

Figure 34 LAF: Interaction Effects Plot for SQRT DEE versus Object Height (3 levels), Object Density (4 levels) 55

Figure 35 LAF: Main Effects Plot for SQRT DEE versus Object Height (4 levels), Object Density (4 levels) 56

Figure 36 LAF: Interaction Effects Plot for SQRT DEE versus Object Height (4 levels), Object Density (4 levels) 56

Figure 37 LAF: Main Effects Plot for LOG AT versus Object Height (3 levels), Object Density (4 levels). 58 
Figure 38 LAF: Interaction Effects Plot for LOG AT versus Object Height (3levels), Object Density (4 levels)

Figure 39 LAF: Main Effects Plot for LOG AT versus Object Height (4 levels), Object Density (4 levels).

Figure 40 LAF: Interaction Effects Plot for LOG AT versus Object Height (4 levels), Object Density (4 levels).

Figure 41 LAF: Main Effects Plot for SEE versus Object Height (3 levels), Object Density (4 levels)

Figure 42 LAF: Interaction Effects Plot for SEE versus Object Height (3 levels), Object Density (4 levels) 62

Figure 43 LAF: Main Effects Plot for SEE versus Object Height (4 levels), Object Density (4 levels) 62

Figure 44 LAF: Interaction Effects Plot for SEE versus Object Height (4 levels), Object Density (4 levels). 63

Figure 45 Object Height Levels and Hover. 65

Figure 46 Hover: Main Effects Plot for SCORE versus Object Height, Object Density 68

Figure 47 Hover: Interaction Plot for SCORE versus Object Height, Object Density .68

Figure 48 LAF: Main Effects Plot for SCORE versus Object Height, Object Density................69

Figure 49 LAF: Interaction Plot for SCORE versus Object Height, Object Density .................. 70

Figure 50 Hover: Residual Plots for DT (4 Object Density *4 Object Size)............................. 89

Figure 51 Hover: Residual Plots for LOG DT (4 Object Density *4 Object Size) ...................... 89

Figure 52 Hover: Residuals Plot for AT (4 Object Density *3 Object Size) ............................ 90

Figure 53 Hover: Residuals Plot for LOG AT (4 Object Density *3 Object Size) ..................... 90

Figure 54 Hover: Residuals Plot for AT (4 Object Density *4 Object Size) ........................... 91

Figure 55 Hover: Residuals Plot for LOG AT (4 Object Density *4 Object Size) ..................... 91

Figure 56 LAF: Residual Pilots for DEE (4 Object Density *3 Object Size) .............................. 92

Figure 57 LAF: Residual Pilots for SQRT DEE (4 Object Density *3 Object Size) .................... 92

Figure 58 LAF: Residuals Plot for DEE (4 Object Density *4 Object Size) .............................. 93

Figure 59 LAF: Residuals Plot for SQRT DEE (4 Object Density *4 Object Size) ...................... 93

Figure 60 LAF: Residuals Plot for AT (4 Object Density *3 Object Size) ................................ 94

Figure 61 LAF: Residuals Plot for LOG AT (4 Object Density *3 Object Size) ........................ 94 
Figure 62 LAF: Residuals Plot for AT (4 Object Density *4 Object Size). 95

Figure 63 LAF: Residuals Plot for LOG AT (4 Object Density *4 Object Size)..... 96

Figure 64 LAF: Residuals Plot for SEE (4 Object Density *3 Object Size) . 96

Figure 65 LAF: Residuals Plot for SEE (4 Object Density *4 Object Size) .96 


\section{LIST OF ABBREVIATIONS AND ACRONYMS}

$\begin{array}{ll}\text { 3D } & \text { : Three Dimensional } \\ \text { AGL } & : \text { Above Ground Level } \\ \text { AT } & : \text { Altitude Travelled } \\ \text { CM } & : \text { Centimeter } \\ \text { CPU } & : \text { Central Processing Unit } \\ \text { CTER } & : \text { Cumulative Transfer Effectiveness Ratio } \\ \text { DEE } & : \text { Distance Estimation error } \\ \text { DEM } & : \text { Digital Elevation Model } \\ \text { DFS } & : \text { Distribution Scenery Format } \\ \text { DT } & : \text { Distance Travelled } \\ \text { FOV } & : \text { Field of View } \\ \text { FT } & : \text { Feet } \\ \text { GHZ } & : \text { Gigahertz } \\ \text { HD } & : \text { Hard Disk } \\ \text { HMD } & : \text { Head Mounted Display } \\ \text { HUD } & : \text { Head Up Display } \\ \text { IFR } & : \text { Instrument Flight Rules } \\ \text { KM } & : \text { Kilometer } \\ \text { KM } & : \text { Kilometer Square } \\ \text { LAF } & : \text { Low Altitude Flight } \\ \text { LCD } & : \text { Liquid Cristal Display } \\ \text { LOG } & : \text { Logarithm } \\ \text { M } & : \text { Meter } \\ & \end{array}$




$\begin{array}{ll}\text { MB } & \text { : Megabyte } \\ \mathrm{MI}^{2} & \text { : Mile Square } \\ \mathrm{MM} & \text { :Millimeter } \\ \text { OTWS } & : \text { Out the Window Scene } \\ \text { PC } & : \text { Personal Computer } \\ \text { PC-FS } & : \text { PC-based Flight Simulator } \\ \text { PPI } & : \text { Pixels per Inch } \\ \text { SD } & : \text { Standard Deviation } \\ \text { SEE } & : \text { Speed Estimation Error } \\ \text { SQRT } & : \text { Square Root } \\ \text { TER } & : \text { Transfer Effectiveness Ratio } \\ \text { VFR } & : \text { Visual Flight Rules }\end{array}$




\section{CHAPTER 1}

\section{INTRODUCTION}

This chapter includes the problem statement and motivation, research questions and organization of the thesis.

\subsection{Problem Statement and Motivation}

Helicopter flight simulators are used in military, commercial and civil aviation for training, research and development. Simulators offer advantages to the users in terms of safety, availability, versatility and cost saving. They can also provide opportunity of training in unlikely and emergency situations. However, enhanced flight simulators are not widely used due to their acquisition, utilization and maintenance problems. PC-based flight simulators (PC-FS) are alternative to enhanced flight simulators with their low cost and portability.

With the improvement in PC and Internet technologies, simulators are more widespread and improve rapidly. Wider use also brings up new questions about simulators in terms of their reliability, validity and risks. Studies show that PC-based simulators affect some stages of aircraft flight training positively. Examples of these stages are procedural training, recurrent training, instrument training and new tasks (D'Alessandro, 2007). However, lack of fidelity gives rise to longer training time and relearning process in some maneuvers.

Effectiveness of PC-based flight simulators have been investigated in many studies. D'Alessandro (2007) conducted a literature survey about the effectiveness of PC-based 
simulators. He stated that previous studies indicate positive training transfer from PC-based simulators to real aircraft.

Effective flight simulators provide pilots with cues that are equals to real world and not cause to wrong learning. The negative transfer of training from simulator to real flight is a serious problem. Therefore, visual and peripheral cues should be clarified in order to determine the effectiveness of the PC-based flight simulators. D. Johnson \& Stewart II, (2005) conducted a utility evaluation for helicopter flight simulator. After using the simulator for a specific task, participants evaluated the simulator. Participants considered that simulators were not suitable for hovering in terms of peripheral visual cues, field of view and visual cues to depth (D. Johnson \& Stewart II, 2005).

Identification of the Out the Window Scene (OTWS) cues, adequate for performance and bringing minimum system load, is a concern for designing an optimized simulator regarding the performance and cost.

A significant amount of research has been done to investigate the required OTWS cues for low altitude flight(JA Kleiss \& Hubbard, (1995); JE Kleiss, (1990); Schnell \& Katherine Lemos, (2002);JA Kleiss, (1995); JA Kleiss, (1992); Pongracic, Doman, Grabovac, Yildiz, \& Smith, (2003); Karaahmetoðlu, Yilmaz, Cetin, \& Köksal, (2006); Peitso, (2002); Lemos, Schnell, Etherington, Vogl, \& Postikov, (2003); De Maio, Rinalducci, Brooks, \& Brunderman, (1983); Keller, Schnell, Lemos, Glaab, \& Parrish, (2003); W. Johnson, Schroeder, Center, \& Field,(1995)). Kleiss studied first on the essential visual cues for low altitude flight and published landmark papers. Details of the previous works that investigated the effect of visual cues for low altitude flight and hover are discussed in Chapter 2. Research for low altitude helicopter flight is limited. Hover, one of the most important helicopter flight tasks, is completely different from jet aircraft flight in term of speed and altitude values. The visual cues needed for hover are fairly high and detailed because of the small movements closer to the surface. 


\subsection{Research Questions}

This study investigates the effects of 3D objects on helicopter flight performance of pilots for hover and low altitude flight on a PC-based flight simulator. Density and height parameters of 3D objects are varied and the distance travelled, altitude travelled, distance estimation and speed estimation performance of the pilot are measured.

This thesis focuses on the following questions:

- What is the required density and height of 3D objects for stable hover and low altitude flight?

- Does the performance increase continuously as the density and height of 3D objects increase?

- Is there an interaction between object density and height on hovering and low altitude flight performance?

- Are the pilot preferences for the scene and their flight performance on that scene consistent?

- Does the experience of the pilots affect their hover and low altitude flight performances on the simulator?

The answers to these questions can be used for determining the quality of OTWS details required for hover and low altitude flight. This information in turn can be used for evaluation of pilot performance and training. In addition effective and cost efficient simulators can be designed.

\subsection{Organization of Thesis}

This thesis is composed of five chapters.

We dedicated Chapter 2 for background information. In this chapter, history of the flight simulator, reasons for using PC-based flight simulator, cues in natural flight context and 3D object parameters for distance perception are presented. Then, an overview of previous works that are on essential visual cues for hover and low altitude flight is given. Finally, the general framework is discussed. 
In Chapter 3, we give the framework of the experiment. Methods used in conducting the experiment, simulator implementation and description of hardware and software components of test platform are presented.

The major findings of this thesis are given in Chapter 4. Learning effect for hover and low altitude flight are analyzed. Model is given and its adequacy is tested. Performance of the pilots in terms of distance travelled, altitude travelled and speed estimation error are analyzed. Then, they are compared with pilot score. Finally, the effect of the experience on performance is investigated.

Finally we wrap up our thesis with conclusions reached from the experimental process and discussed future works in Chapter 6. 


\section{CHAPTER 2}

\section{BACKGROUND}

This chapter composed of three sections. First, a general background on flight simulators and related cues for flights are given, and 3D object properties and distance perception are discussed. Then, previous works are summarized. Finally, the framework of the study is given.

\subsection{Flight Simulators}

Flight simulators have been used standing World War II. They became more widespread with the technological improvements like speed and accessibility. These improvements diverted the trainers' and simulator designers' attentions to the simulator area. Cost saving and positive training transfer are the major advantages of the flight simulators and these advantages enabled the integration of simulators to the flight training program. Today, many organizations use the PC-based simulators as a part of their flight training program. In spite of the development in simulator area, PC-based flight simulators are not appreciated universally from the aviation area (Authorities, JA, 1998).

\subsubsection{History of Flight Simulators}

First flight simulator was the Link Trainer. This simulator was created by Edwin Link at 1920s (ASME International, 2000). It was used for instrument training. In World War II, new aircrafts were produced and demand for new pilots was raised. In order to meet the pilot 
demand simulators that replicated the cockpit of new aircrafts were produced. Also, they reduced cost and risks.

After World War II, simulation industry redirected their route to commercial airline industry. Parallel with the technological improvement during the World War II, aircrafts flying under all weather conditions were introduced. Therefore, demand for training program arose. Simulators introduced after World War II were very complicated, costly and not suitable for general aviation needs.

In $20^{\text {th }}$ century, information industry grew rapidly. Simulators were improved in terms of motion, visual fidelity and performance.

\subsubsection{Types of Flight Simulators}

Simulators can be grouped under four categories according to their purposes. These are system evaluation simulator, pilot training simulator, human performance research simulator, and system performance investigation simulator (Stanton, 1996).

Simulators have three major facets;

- Model; determined by the purpose of the system (i.e. research, training),

- Equipment (i.e. high fidelity parts),

- Application (i.e. industry, army, aerospace)( Stanton, (1996); D'Alessandro, (2007)).

There are many reasons for the use of simulators. First, simulators provide a safe and controllable environment to the users. The tasks that are dangerous in a real environment might be experienced on simulator. Emergency situations can be produced and pilots gain experience on this situation without risks. Second, measurement of performance is easier with simulators. Third, simulators provide reproducibility and reduce task difference. They allow pilots to fly in any weather and at any time condition. Finally, use of simulators is more economic than use of real aircraft or helicopter because they do not depreciate and consume fuel. They are also friendlier to the environment (AOPA, (1998); McDermott, J. (2006)). 


\subsubsection{Simulator Fidelity}

Simulator fidelity indicates that degree of correspondence between simulated and real environments. There are several categories of simulator fidelity. These are physical, functional, psychological, motivational, engineering, operational, task and workload fidelity (Pongracic, Marlow and Triggs, 1997). Physical fidelity, refers to the degree to which the physical features of simulator (i.e. visual, motion, sensory and auditory) similar with the real environment. Functional fidelity refers to the match between simulation acts and the real environment.

High fidelity refers to full replicate of the real system with motion. Whereas low fidelity refers to system that omits some properties of real system such as motion. There is no exact description to classify the simulators as high or low degree of fidelity. The proper categorization is done according to the goal of the user. For example, if the purpose is instrument training, there is no need for full visual replication. The simulator with no visual replication of cockpit and instruments could be high fidelity for instrument training.

\subsubsection{PC-based Flight Simulators}

Evolution of PC-based flight simulators can be summarized as below.

1970s-Emergence of the personal computer

1980- First PC-based simulator produced by Bruce Artwick. It was run on TRS80 and Apple II computers (Bruce Artwick, 2008).

1982-Microsoft developed a flight simulator. Current version is Flight Simulator $X$ (Microsoft, 2008).

1995-1996-Laminar Research introduced the X-Plane. Current version is X-Plane 9 (X-Plane, 2008).

1996-Open source flight simulator Flight Gear was introduced. Current version is v1.0 (Flight Gear, 2008).

One of the properties of the effective flight simulators is positive training transfer from simulator to the real aircraft. Two formulas for calculating the training transfer are given below. 
- TER (Transfer Effectiveness Ratio) (adapted from Willigies, 1980)

$$
T E R=\frac{T s-T a}{N s}
$$

Ts= Trials in airplane by simulator group

$T a=$ Trials in airplane by control group

$N s=$ Number of trials in simulator by simulator group

- CTER( Cumulative Transfer Effectiveness Ratio)(adapted from Roscoe, 1971)

$$
C T E R=\frac{N a i-N s i}{N i}
$$

$N a i=$ Number of iteration in the aircraft without simulator .

$N s i=$ Number of iteration after $N i$ simulator training

$\mathrm{Ni}=$ Number of simulator training

There are a great amount of studies that investigated the transfer of training from simulator to real aircraft. Some of them found positive training transfer (Macchiarella \& Brady, 2006; McDermott,2006) whereas others found negative training transfer (Thatcher S., Fyfe A., Jones C. \& Ong-Aree J., 2006; Williams 2006). D'Alessandro (2007) conducted a literature survey that covers the studies which investigated the effectiveness of flight simulator and transfer of training from 1997 to 2007.

\subsubsection{Cues and Flight Types}

In actual flights, pilots use cues to perceive:

- position ( horizontal and vertical locations),

- orientation(pitch, roll and yaw angles),

- rate of change in the speed, altitude and direction.

There are three types of cues that are used in actual flight. These are visual, vestibular and informational cues. Visual cues are provided by the OTWS components. Terrain shape, surface texture and 3D objects are the essential visual cues (Kleiss, 1990). Their rate of 
change in terms of size and location gives information about the position and altitude. Vestibular cues are provided by the motion system. However, their usage without other types of cues can cause misperception and loss of control. Informational cues are obtained from cockpit instrument like speed and altitude indicators.

Required cues for flight are determined according to flight type. Pilots use visual cues more frequently at low altitude flight and hover. They do not have enough time to analyze the instrumental flight to avoid collision with terrain. Hover is performed at 3-15 feet above the ground with zero speed. In hover, pilots try to stabilize the helicopter along horizontal and vertical dimensions. Therefore, pilots need significant amount of visual cues for hover. At high altitude flight pilots use instrument and informational cues more than visual cues. Because of the high distance from the ground, OTWS components cannot provide enough information about the location, rate of change and altitude (Karaahmetoğlu, 2005).

\subsubsection{D Objects and Distance Perception}

3D objects are one of the required cues for flight. The cues that are used for distance perception are given below. Then, object categorization and parameter selection of this study is discussed.

Distance perception is the essential skill for navigation and flying tasks. It is used for eliminating the collision with the ground or an object. In order to estimate the distance pilot used depth cues. Depth perception is the visual ability to perceive the world in three dimensions. Depth cues can be categorized under two groups; monocular and binocular depth cues.

Monocular visual cues for depth perception are explained below.

- Perspective: Perspective which is a depth cue from different viewpoints objects appears different. It has three types; size gradients, texture gradients and aerial perspective. Size gradient refers to more distant object shown smaller and located higher on the scene. Texture gradient means that when the distance increases, 
texture density of object increases while its size decreases. Contrast of the object decreases with distance due to aerial perspective (Forsell, 2007).

- Size: Two known size objects can be compared with their size on the scene. For example, if a person and an apartment are same size, the person is closer to the viewer (Bigham, 2000).

- Interposition: Closer object can block the distant object.

- Lighting and Shadow: Cast shadow gives information about the distance between the overlapping objects (Naikar, 1998).

Binocular visual cues for depth perception are explained below.

- Convergence: Viewers point their eyes inward to converge on an object that is close to them (Bigham, 2000).

- Binocular disparity: Images are projected to the left and right eyes differently. This difference produces binocular disparity (Bigham, 2000).

- Motion Parallax: The object in the background move less than object in foreground (Forsell, 2007).

Objects can also be divided according to their dimensions. There are two types of objects; 2D and 3D. Also, they can be categorized if they are natural or manmade (Table 1).

Table 1: Object Classification

\begin{tabular}{lll}
\hline Object Classification & Natural & Manmade \\
\hline 2D Object & River & Road \\
3D Object & Tree & Building \\
& Shrub & Lamppost \\
& Hill & Water Depot \\
\hline
\end{tabular}

3D object parameters that can be investigated in terms of their effect on altitude and distance perception are vertical size, uniformity, density, distance, distribution of object, discrimination, shape and background. Vertical size parameter can be analyzed by comparing the high, medium and small size objects. For uniformity, sceneries that are composed of same object or different objects can be compared. Different object densities 
and randomly or uniformly distributed objects can be analyzed. Also, effect of discrimination can be investigated by adding a different object to scene such as a red tree with many green trees. Moreover, objects that have different shape like tetrahedron, tree and conic can be compared.

The 3D object used in the study was a tree. Vertical size, density and uniformity parameters were analyzed.

In addition, objects can be classified bound on their stationarity. This study covers only stationary objects. Moving objects will be analyzed in a further study.

\subsection{Related Works}

Effectiveness of OTWS constituents for low altitude flight has been investigated by many researchers. These studies mainly concentrate on essential visual cues for low altitude high speed flight. However, helicopter flight task differ from aircraft in terms of altitude and speed.

Kleiss, (1990) found that pilot performance at low altitude is affected by three OTWS constituents. These are terrain shape, surface texture and 3D objects.

Previous studies that investigate essential visual cues for low altitude flight are summarized below. Unless otherwise specified, the studies are conducted for airplanes cruising at low altitudes.

\subsubsection{Terrain Shape}

Kleiss \& Hubbard, (1995) at 150 feet and 450 knot speed, found that stand-alone terrain shape has no effect on altitude perception. They also investigated the effect of terrain shape and object grouping interaction. Object grouping had three levels; no objects evenly spaced objects and grouped objects. It was found that detection of altitude change was positively affected by interaction of terrain shape and object grouping. 
Karaahmetoğlu, Yilmaz, Yardimci Cetin, \& Köksal (2006) conducted an experiment by using a PC-based helicopter simulator used for hover. They claimed that terrain shape has a significant effect on drift performance but it does not affect the vertical hovering performance. Drift performance was improved with hilly and moundy terrain.

\subsubsection{Surface Texture}

Kleiss (1992) conducted an experiment that investigated if complex texture reduces the need of vertical object density to detect altitude change. He found that texture had positive effect of on determining altitude change. However, texture could not eliminate the vertical object requirement. Moreover, subjects detected altitude change more quickly and correctly when a vertical object was present.

Pongracic et al. (2003) compared the effect of rich, sandy desert and none texture on altitude perception. Participants' task was flying at $100 \mathrm{~m}$ altitude above highest point on the scene. Deviation from the $100 \mathrm{~m}$ altitude was scored. They found that more complex surface texture improved altitude perception of pilots.

\subsubsection{D Object}

Related work about 3D objects can be grouped under four categories.

\subsubsection{Object Type}

Kleiss (1992) with a 150 feet initial altitude and 450 knot constant speed, found that improving level of objects' detail, i.e. tetrahedron(low-level detail) and pine tree(high-level detail), did not affect the detection of altitude change performance of pilots. Altitude and speed values of this experiment were typical to jet aircraft that are not suitable for hover (5-15 feet with zero speed). Therefore, levels of object detail might be important for hover task. This issue should be investigated.

\subsubsection{Object Density}

Peitso (2002) conducted an experiment with a PC-based helicopter simulator to determine the required object density for hovering. He found that 3D object density is effective on positional stability and perceived drift. He compared $1 \%, 0.25 \%, 0 \%$ density of $3 \mathrm{D}$ 
vegetation on pilots' drift performance (1\% refers to one object on average per $100 \mathrm{~m}^{2}$ $\left(\sim 10000\right.$ objects per $\left.\mathrm{km}^{2}\right)$ ). He found that required density is around $1 \%$. The flight simulator used in the experiment had a stabilization problem due to implementation limitation. Therefore, altitude stabilization was not tested.

De Maio et al. (1983) , with 10 experienced pilots at 600 knot and 150 feet AGL, found that $3 \mathrm{D}$ objects are effective on altitude estimation. Also, they stated that $12-15$ objects per $\mathrm{mi}^{2}$ $\left(1 \mathrm{mi}^{2}=2.5899 \mathrm{~km}^{2}, 12-15\right.$ objects per square mile $=4.63-5.79$ objects per $\left.\mathrm{km}^{2}\right)$ are sufficient for maintaining altitude (as cited in Chung, 2000).

Kleiss, (1992) in his investigation with 12 professional pilots, tried effects of 4, 17 and 67 objects per $\mathrm{km}^{2}$ object densities on pilots' detection of altitude change. Task of participants was pushing forward a joystick to indicate ascent and pulled back to indicate descent. Both percentage of correct response and reaction time improved when vertical object density increased.

In a visual environment at a speed of 400 knot and 100 meter(328.084 feet) AGL with 12 pilots, Pongracic et al. (2003) measured the time of the deviation from the $100 \mathrm{~m}$ altitude with $\pm 20 \mathrm{~m}$ toleration. They found that more than 4 objects per $\mathrm{km}^{2}$ was sufficient for altitude control. Also, altitude control performance did not significantly increase with higher object density.

In order to determine the required object density for low altitude flight many experiments were conducted (Kleiss (1992); Pongracic et al.(2003); Peitso (2002); De Maio et al. (1983)). However, most of them were carried out at high speeds that are not suitable for hovering. Furthermore, previous studies only analyze the essential minimum object density. However, there can be a breaking point at which further increasing the 3D objects on the scene causes a decrease in the hovering performance. Therefore, minimum and maximum object densities essential for lateral and longitudinal hovering should be investigated. 


\subsubsection{Distribution of Objects}

A study conducted by Kleiss \& Hubbard (1995), at 450 knot and 150 feet initial altitude, compares the effect of none, evenly spaced and grouped objects on altitude perception. Result show that perception of altitude change was positively affected by object grouping.

Another dimension of object distribution is spacing. Spacing can be random or uniform. Hover is performed at extremely low altitudes (3-15 feet). It is conceivable that the vertical and horizontal positional offset can be detected quicker in uniformly spaced scenes than randomly spaced scenes. Occlusion can be an important cue at low altitude. In order to clarify the effect of occlusion on hovering, random and uniform distribution of objects should be investigated.

\subsubsection{Object Height}

Pongracic et al. (2003) claimed that altitude control would improve if the height of the object increased. However, they did not carry out any experiment to prove this claim. We could not found a study that investigates the effect of 3D objects' height in terms of uniformity; i.e. scene composed equal height vs. different height objects. Therefore, effect of height of objects should be investigated to close these gaps.

\subsubsection{Resolution}

Previous research that investigated the resolution can be analyzed under three categories. These are texture resolution, DEM (Digital Elevation Model) resolution (the horizontal spacing of points in the elevation grid) and display resolution.

Karaahmetoğlu et al. (2006), with 10 military pilots, conducted a PC-based helicopter simulation experiment. They found that texture resolution did not affect the horizontal and vertical hovering performance unless 2D objects were visible on texture.

Schnell et al. (2002) conducted 3 experiments that compared static image representation, dynamic image representation and pilot navigation for positional offset detection. They compared 3 arc second, 6 arc second, 15 arc second and 30 arc second DEM resolutions. 
Results showed that in static image representation resolution had no significant effect on determination of vertical and horizontal position, whereas in dynamic image representation resolution affected performance significantly. However, horizontal stabilization performance of pilots was significantly affected by DEM resolution.

Keller et al. (2003) , with 34 pilots at 1000 feet AGL, conducted an experiment to find the minimum required display resolution. They compared 80 ppi (worst), 90 ppi, 105 ppi, 120 ppi (best) display resolutions. They found that display resolution has a positive effect on lateral stabilization performance. However, resolution higher than 105 ppi resulted in no additional performance benefit.

\subsubsection{Shading}

The effect of shading at static, dynamic image representation and pilot navigation was investigated by comparing flat, gouraud and no shading. (Lemos, et al., 2003).Results showed that shading has a significant effect on response time in static, dynamic image representation and pilot navigation. Also, performance was affected by shading in a dynamic image representation (percent correct terrain identification) and pilot navigation (horizontal stabilization).

\subsubsection{Level of Detail (LOD)}

In order to find the effect of visual LOD on altitude repositioning, W. Johnson et al. (1995) conducted an experiment by using AH-64 Apache helicopter simulation. They compared the LOD constancy (low, medium and high) and found that usage of constant LOD improved altitude estimation performance of pilots.

\subsubsection{Field of View (FOV)}

Chung, Sweet, Kaiser, \& Lewis (2003) compared the narrow FOV vs. wide FOV and collimated display vs. non collimated display in terms of their effect on hovering performance. Results showed that FOV and display collimation have a significant effect on hovering performance. Also, pilots preferred wide FOV. 


\subsection{General Framework}

The properties of previous works can be summarized as below:

- Previous works had three display types; picture, video segment and flight simulator.

- Professional pilots or non-pilot people were used as subjects.

- Different equipment was used: rating scale, sticks that had control on vertical or horizontal dimension, sticks that had two dimensions control and full control with pedal, stick and yaw.

- Performance measures were ease of navigation, vertical and horizontal stabilization.

After analyzing the previous works, we constructed a framework for further analysis:

- Participants are composed of pilot, hobbyist and non-pilot.

- Three types of scenes are displayed to the subjects. These are static image, dynamic image and pc-based simulator OTWS. Static images are obtained from flight simulator as screen shots. Dynamic images are produced in movie format from flight simulator. In navigation scenes, subjects have full control of PC-based helicopter simulator.

In this framework, the scene is assumed static, i.e. there are no moving objects. The term "dynamic image" refers to changing scene due to the movement of the viewer which is the result of the helicopter motion.

Framework is explained according to the subject type in three stages (from simplest to the most complicated) below.

Design of the experiment has three options. In first option, only professional helicopter pilots are the subjects. In a static image task, two static images are shown to the pilot and asked if there is a difference between them according to measured performance. For example, if altitude perception is investigated, difference of altitude could be asked. In a dynamic image task, two video are shown. Then, a similar question as the static image task 
could be asked. In a navigation task, pilot flies with PC-based flight simulator. This design analyzes the effect of motion with and without control and compares them (Figure1).

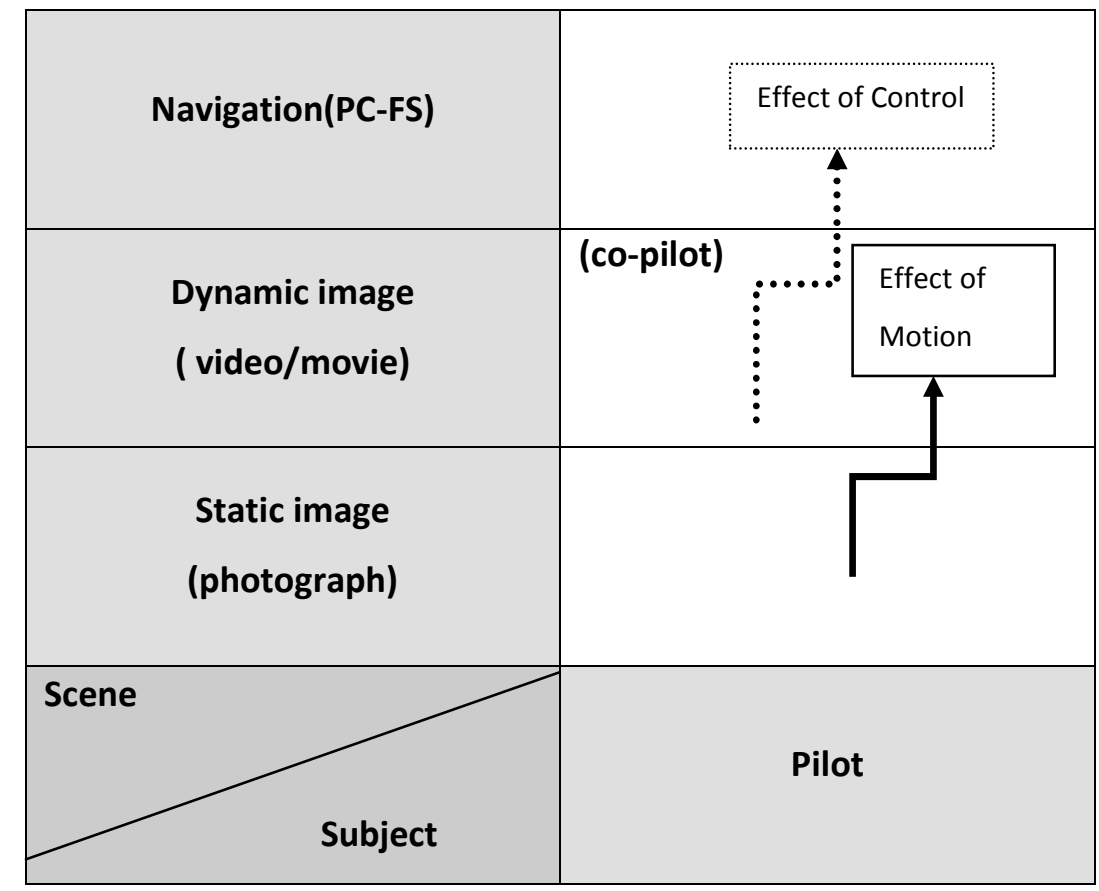

Figure 1: Subject Groups and Scene Presentation (Option1)

In the second option, professional pilots and non-pilot people are taken on the subjects. Static image and dynamic image task are same with option 1. Non-pilot group can participate in the static and dynamic image tasks. Since they did not take pilot training, nonpilot groups cannot participate in the navigation task. Effects of motion and pilot training can be investigated by comparing pilot and non-pilot group (Figure2).

In third option, three groups; professional pilots, hobbyist and non-pilot people comprise all subjects. Tasks of this option are the same as the option1's. Non-pilot group participate the static and dynamic image tasks. Although they did not take pilot training, hobbyist group participate in the navigation task. In this option, pilot and two non-pilot groups are compared in terms of effects of motion, pilot training and simulator interest on performance (Figure 3). 
Response variables are different for pilot, hobbyist and non-pilot groups. In a navigation task response are determined according to the flight type. For example, if the hover is investigated, the distance travelled data could be a response. In a dynamic and static image tasks percentage correct and response time could be measured. Also, ease of navigation could be a response for all tasks.

Because of the time constraints, only professional pilot groups on the navigation were tested at the experiment.

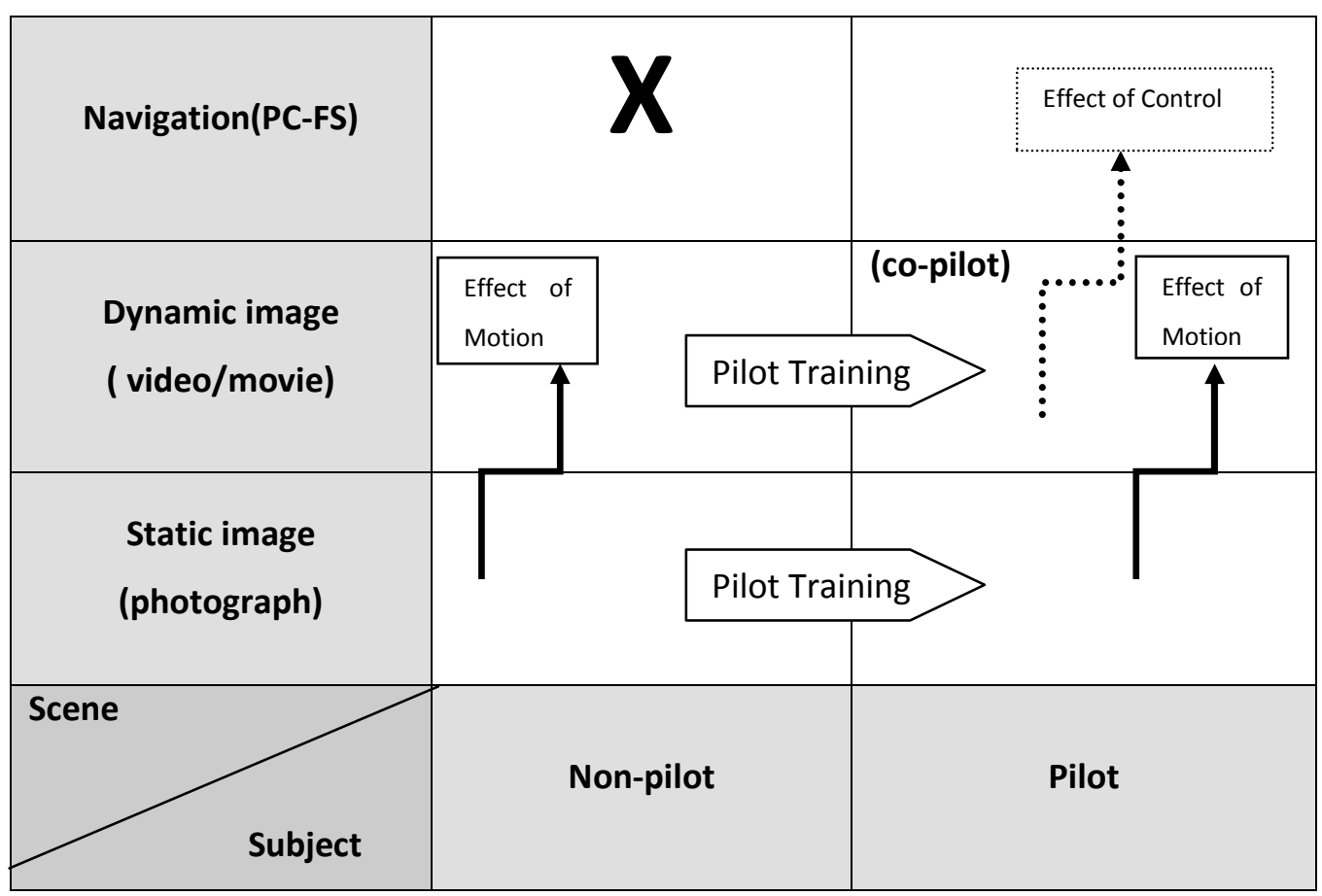

Figure 2: Subject Groups and Scene Presentation (Option2) 


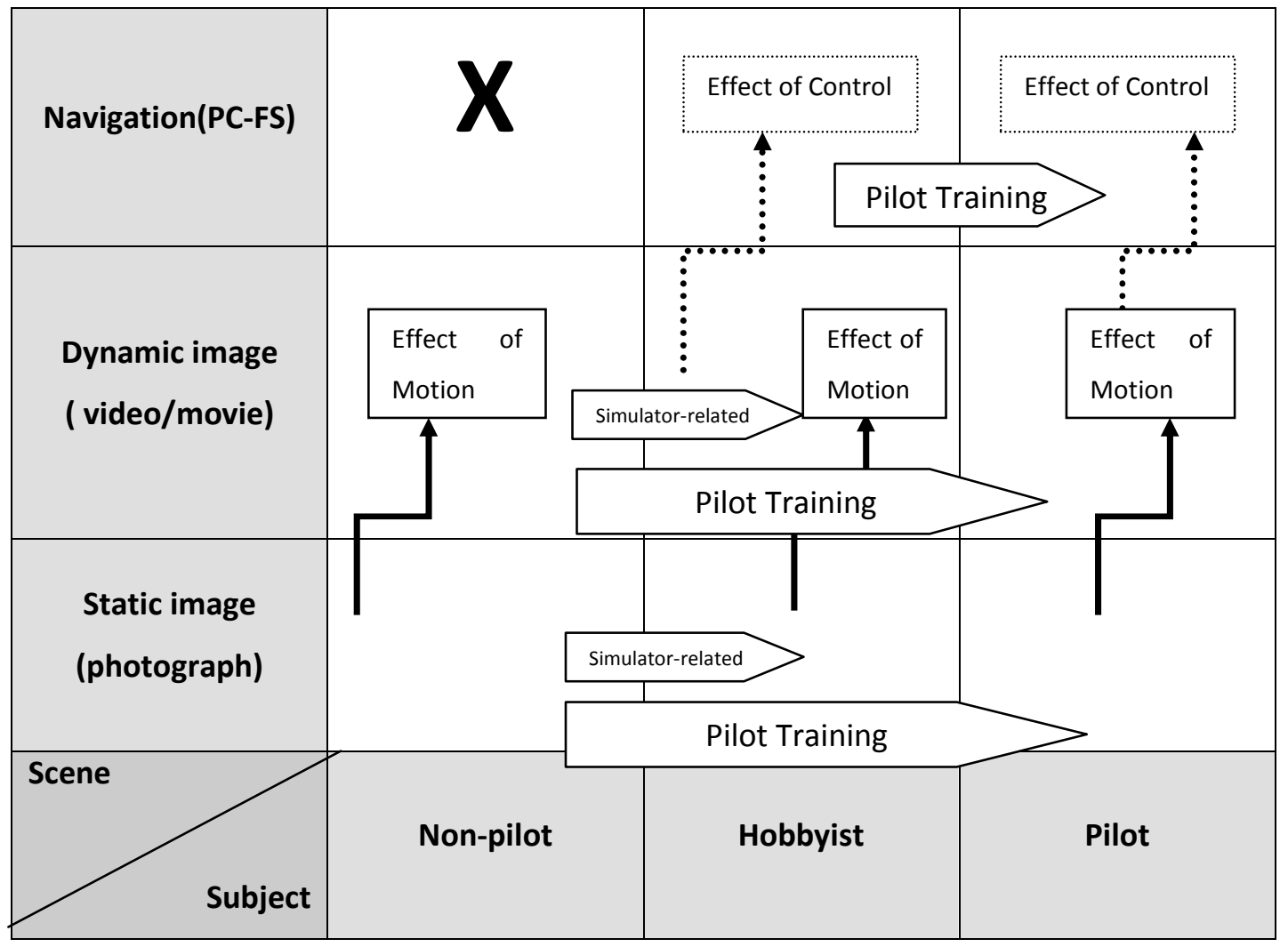

Figure 3: Subject Groups and Scene Presentation (Option3) 


\section{CHAPTER 3}

\section{EXPERIMENT DESIGN}

This chapter includes design, software, hardware, design factors and procedure of the experiment.

\subsection{Subjects}

Ten male professional helicopter pilots participated in the experiment. All participants had normal or corrected to the normal vision. Mean age of participants was 28.9 (SD=1.3 Range: 27 to 33) and mean total flight hours was 1072 ( $S D=293.4$ Range $=580$ to 1850). Average elapsed time from last flight was 4.2 days ( $S D=4.2$ Range=1 to 7 ).

Experiments were scheduled as a single session according to the pilot's schedule. Participants were informed about the purpose of the experiment.

\subsection{Location}

The experiment was carried out at Kara Havacılık Okul Komutanlığı. Windows of the room were closed with blinds and the room was illuminated with lamp. Participants sat at an approximately $80 \mathrm{~cm}$ from the center monitor.

\subsection{Equipment}

Equipment that was used in previous studies by other researchers is listed in Table 2. Definition and usage of the equipment are given below. 
Table 2 Used Equipment of Previous Research

\begin{tabular}{|c|c|c|c|c|c|c|}
\hline $\begin{array}{l}\text { Author(s) of the } \\
\text { study }\end{array}$ & $\begin{array}{l}\text { Rating } \\
\text { Scale }\end{array}$ & $\begin{array}{l}\text { Response } \\
\text { Box }\end{array}$ & Stick & $\stackrel{\text { Stick }}{\leftrightarrow}$ & $\begin{array}{l}\text { Full } \\
\text { Control }\end{array}$ & FOV \\
\hline Kleiss (1992) & & & $v$ & & & 6 CRT projectors \\
\hline Kleiss (1995) & $\sqrt{ }$ & & & & & 3 CRT projectors \\
\hline $\begin{array}{l}\text { Kleiss \& Hubbard } \\
\text { (1995) }\end{array}$ & & $\sqrt{ }$ & & & & 3 projectors \\
\hline Peitso (2002) & & & & & $\mathbf{v}$ & $\begin{array}{l}17 \text { " widescreen } \\
\text { monitor }\end{array}$ \\
\hline Schnell et al. (2002) & & & & $\sqrt{ }$ & & $\begin{array}{l}2 \quad 17^{\prime \prime} \quad \text { PC } \\
\text { monitors }\end{array}$ \\
\hline $\begin{array}{l}\text { Pongracic et al. } \\
(2003)\end{array}$ & & & $\mathbf{v}$ & & & 3 LCD Projectors \\
\hline $\begin{array}{l}\text { Karaahmetoğlu et } \\
\text { al. (2006) }\end{array}$ & & & & & v & 3 19" LCDs \\
\hline
\end{tabular}

Rating scale: Rating scale was used by Kleiss (1995) to found the essential visual cues for the OTWS. In this study the participant watched two video segment pairs with 2-4 second break between them. Then participant ranked the scene according to similarity of the two video segments. The scale, of $120 \mathrm{~mm}$ length, had two labels; "Same" on the left and "Different" on the right.

Response box: In a study conducted by Kleiss \& Hubbard (1995) response box was used as a response tool. Participants pushed one of the two buttons on the response box to indicate altitude change (upward or downward).

Stick $\quad$ : Joystick was used by Kleiss (1992) in an experiment. Participants were pushed joystick forward to indicate ascent and pulled it back to indicate descent. In a study conducted by Pongracic et al. (2003) the stick was used by participants to control the altitude of the aircraft. Participants' task was maintaining the $100 \mathrm{~m}$ height at 400 knots constant speed for 3 minutes. When the participant pushed the stick to move the aircraft higher, aircraft flied like a balloon.

Stick $\leftrightarrow$ : Schnell et al. (2002) conducted an experiment in which the task was following the valley while keeping maximum lateral separation from the sides of the valley. 
Full Control: Studies conducted by Karaahmeoğlu et al. (2006) and Peitso (2002) gave both vertical and horizontal position control to participants via pedals, collective and stick.

FOV (Field of View): According to Chung (2003) hovering performance was positively affected by wider FOV. Also, wide FOV was preferred by pilots.

Therefore, three 19" LCDs will be used for this experiment. Furthermore, pilots had full simulator control that includes pitch, roll and heading.

A PC-based flight simulator was constructed for our experiment by using commercially available hardware. System composed of one PC, three LCD monitors, one graphics card for dividing the scene into three displays and flight controls (Figure 4, Figure5 and Figure6). Detailed information of the system component is given in Table 3.

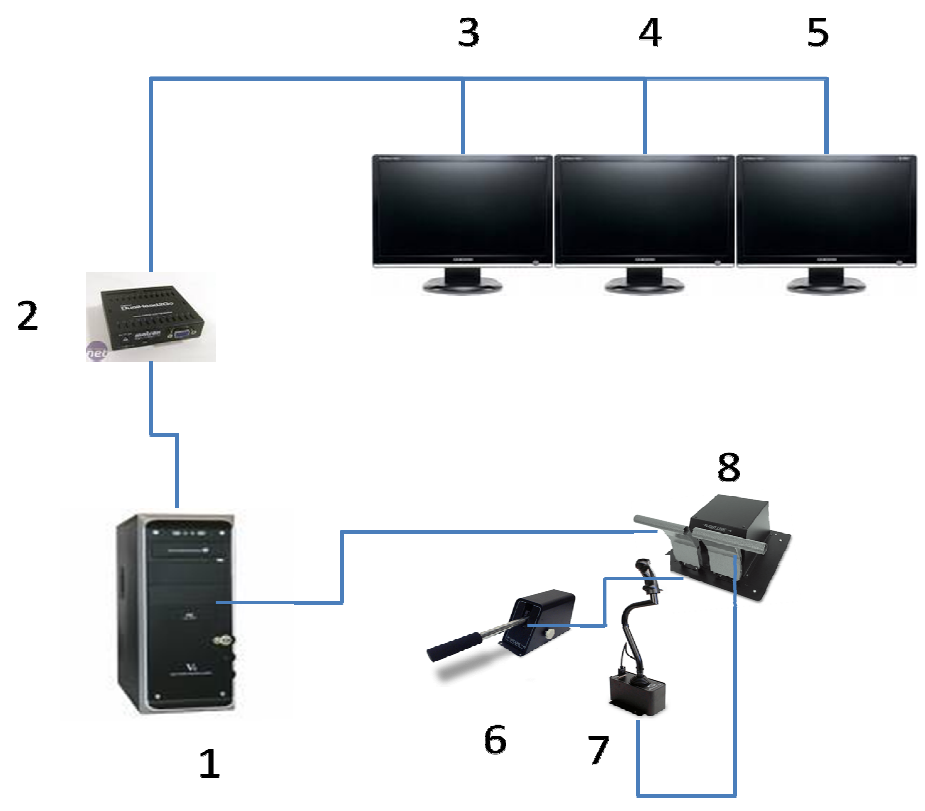

Figure 4 System Scheme 
Table 3 Components of System

\begin{tabular}{lll}
\hline No & Component & Description \\
\hline $\mathbf{1}$ & PC & $\begin{array}{l}\text { Intel(R) Core(TM) 2 Quad CPU Q6600 @ 2.40GHz } \\
\text { Processor, 4096 MB DDR2-SDRAM, X GB HD. } \\
\end{array}$ \\
& & $\begin{array}{l}\text { 2 NVIDIA GeForce 8800 GTS 512 MB graphics } \\
\text { adapter. }\end{array}$ \\
$\mathbf{2}$ & Graphics Card & Matrox DualHead2Go(allows to use 3 displays) \\
$\mathbf{3}$ & Left Monitor & Philips 19 inch LCD \\
$\mathbf{4}$ & Center Monitor & Philips 19 inch LCD \\
$\mathbf{5}$ & Right Monitor & Philips 19 inch LCD \\
$\mathbf{6}$ & Collective Control Stick & Flight Link Collective \\
$\mathbf{7}$ & Cyclic Control Stick & Flight Link G-Stick III \\
$\mathbf{8}$ & Yaw Control Stick & Flight Link Anti-Torque Pedals \\
\hline
\end{tabular}

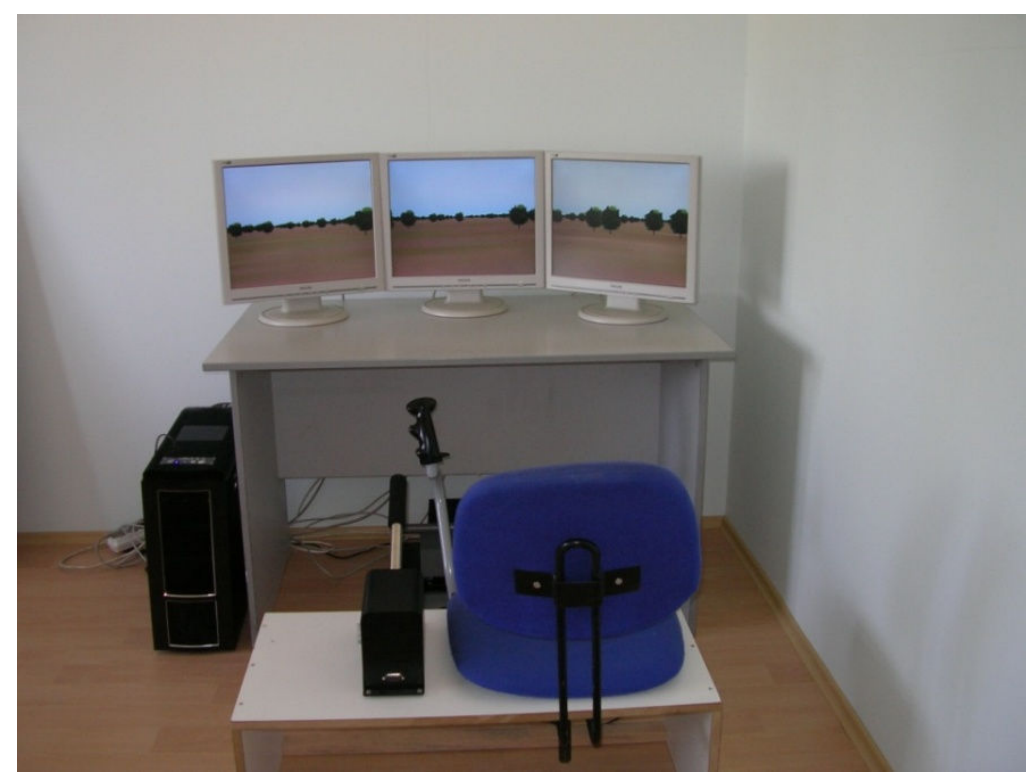

Figure 5 System Overview

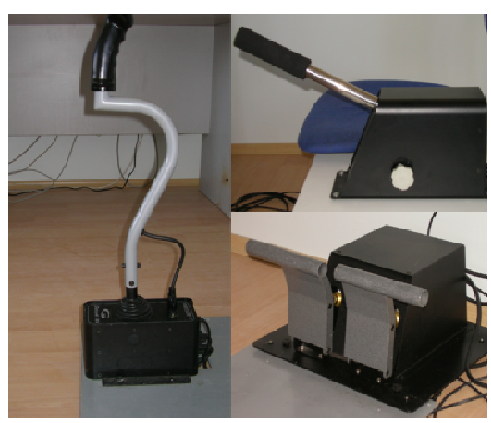

Figure 6 Flight Controls 


\subsection{Software}

In this study, X-Plane, Overlay Editor and Google Sketch Up were used.

X-Plane ${ }^{\circledR}$ : X-Plane is a flight simulator for PCs produced by Laminar Research (X-Plane, 2008). X-Plane version 9.0 was used in this study. It is preferred due to its flexible and realistic structure. Sceneries of X-Plane are editable by the user. Once the new scenery created, locations of the 3D objects are specified by using the scenery editor. Also, 3D mesh objects are editable by third party software like Google Sketch Up.

In the experiment, instrument panel of the helicopter was not shown to the participants. In order to eliminate the effect of informational cues provided via flight instruments like altimeter and barometer, without HUD (Head Up Display) view was chosen (Figure 7). Screen resolution was set to the $3840 \times 1024$. Helicopter type used in the experiment was S-61 Sea King. It has 16, $96 \mathrm{~m}$ length and 5,13m height.

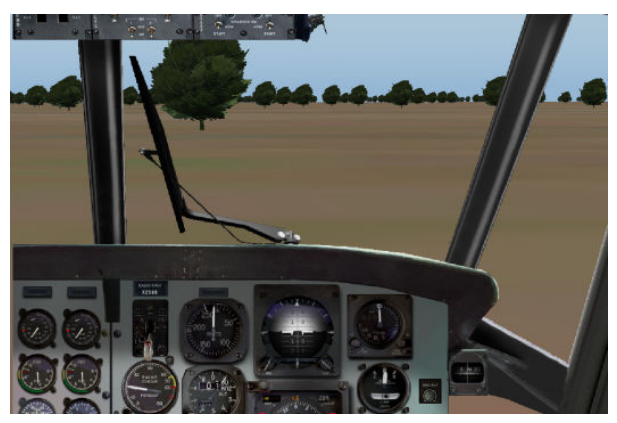

Panel with HUD

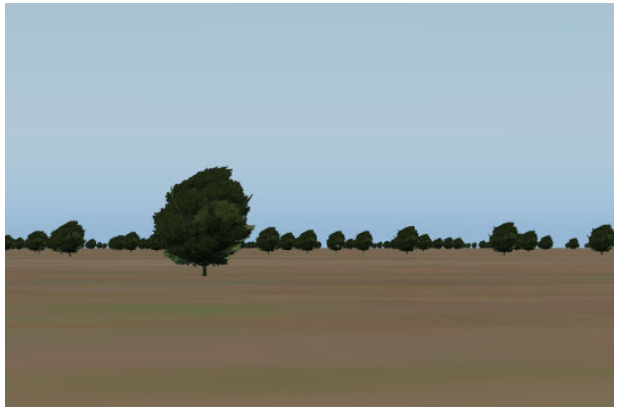

Panel without HUD

Figure 7 Screen Shots of the Panels

Data of the flight was recorded via Data Input \& Output tool of X-Plane (Figure 8). This tool creates text document in .txt format with the parameters specified at data output screen. Time, speed, altitude and location data were especially recorded at one second intervals for further references.

Overlay Editor: Overlay Editor Version 2.00 was used for scene generation (Figure 9). Overlay Editor edits X-Plane DSF (Distribution Scenery Format) overlay scenery packages for X-Plane. Sceneries of the experiment were created by Overlay Editor in two steps. First, 
new scenery was created. Then, objects were randomly distributed in the scene. Number of objects on the scene was determined by the object density parameters. It has four levels; $36,144,576$ and 1296 objects per $\mathrm{km}^{2}$. Also, there were three different objects that have $2 \mathrm{~m}, 5 \mathrm{~m}$ and 10 heights.

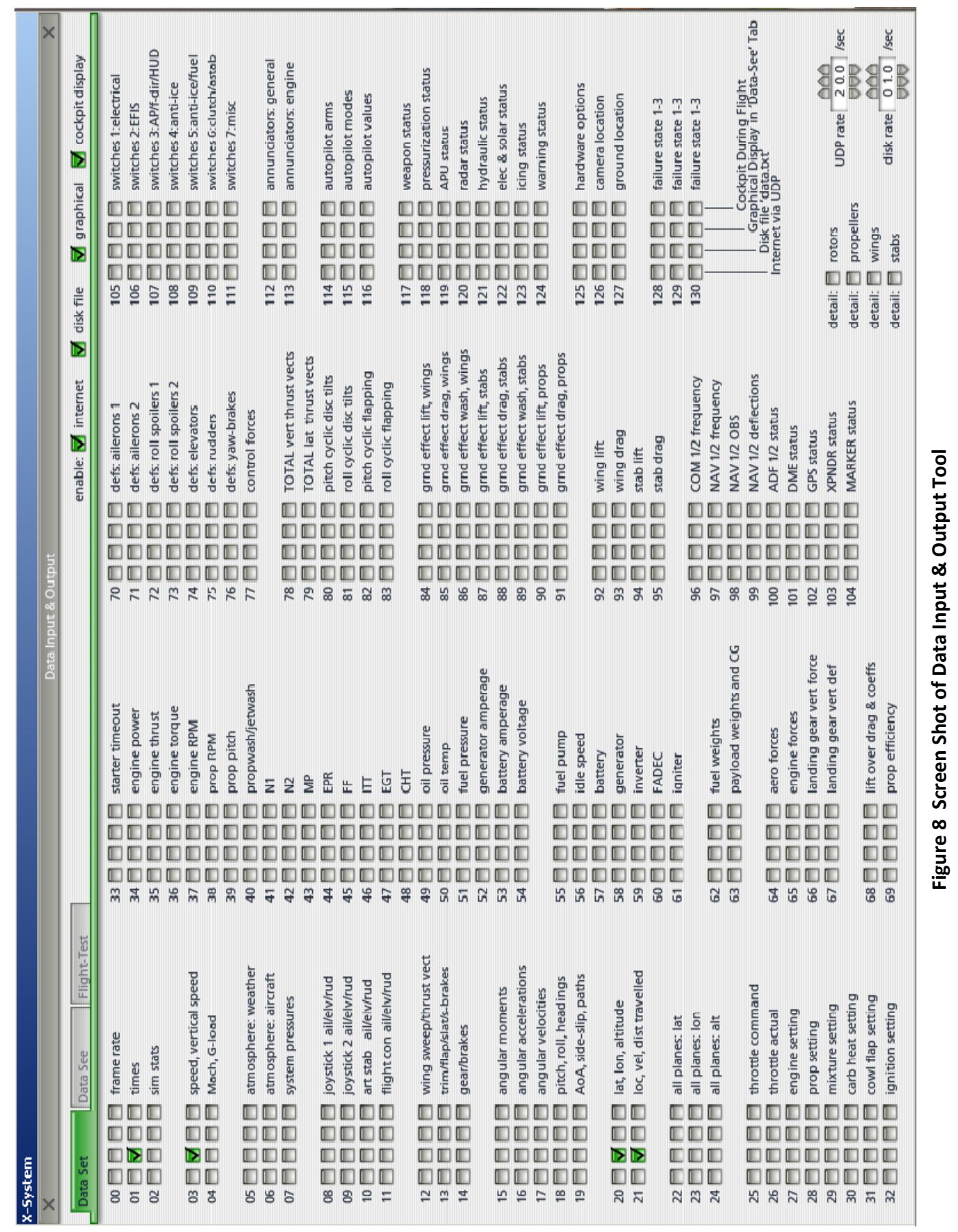




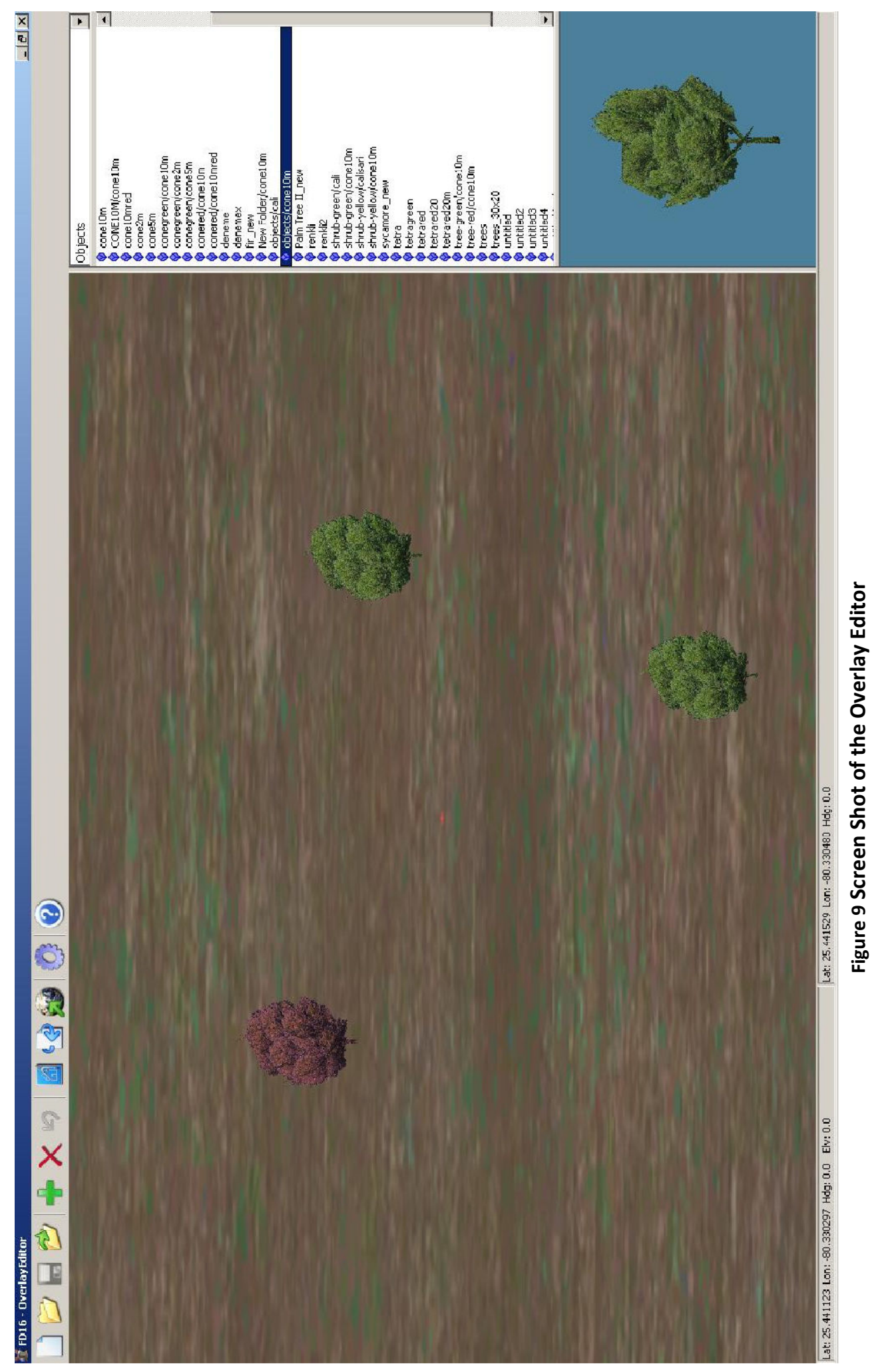


Google SketchUp: Google SketchUp is used to create, modify and share 3D models. Google Sketch Up has a plug-in that enables to save the object in .obj format for X-Plane. Version 6 was used to create the 3D objects (trees). Three tree models that have same shape but different in height and orientation were built. Vertical dimensions of trees are $2 \mathrm{~m}, 5 \mathrm{~m}$ and $10 \mathrm{~m}$.

\subsection{Design Factors}

Design factors of this experiment were object height and density (Table 4). In this study, the 3D objects are trees built via Google SketchUp 6. Trees have identical shape but different orientations. The scenes vary according to height and density of trees.

Table 4 Design Factors

\begin{tabular}{lcl}
\hline Design Factors & Level & Range \\
\hline Height & 4 & $2 \mathrm{~m}, 5 \mathrm{~m}, 10 \mathrm{~m}$, mixture \\
Density & 4 & $36,144,576,1296$ objects per $\mathrm{km}^{2}$ \\
\hline
\end{tabular}

\subsubsection{Height}

In this experiment height of 3D objects has three levels; $2 \mathrm{~m}, 5 \mathrm{~m}$ and $10 \mathrm{~m}$. In the first three levels, the trees have uniform height. On the fourth level, a mixture of all three trees is used in the same scene with the same probability.

\subsubsection{Density}

This experiment has four object density levels; 36, 144, 576 and 1296 objects per km². "36 objects per $\mathrm{km}^{2 \prime \prime}$ means that scene contains 36 objects in one $\mathrm{km}^{2}$ area. Trees were randomly distributed in the scene.

Experiment consisted of 16 runs. Each run had a different object height and object density combination. Therefore 16 different scenes were prepared for the experiment. In Figure 10 and Figure 11, two samples for each factor from the different viewpoints and altitudes are given. 


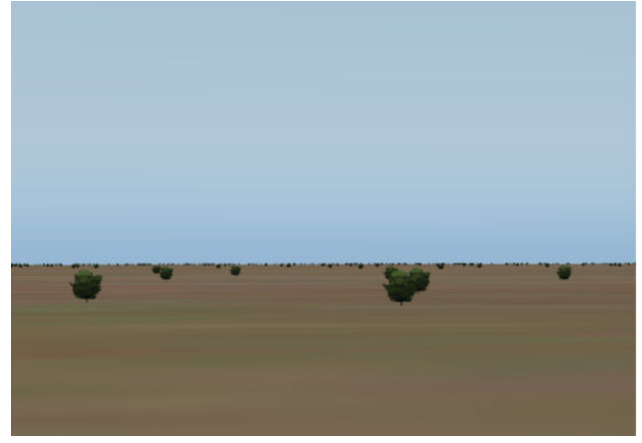

$2 m$

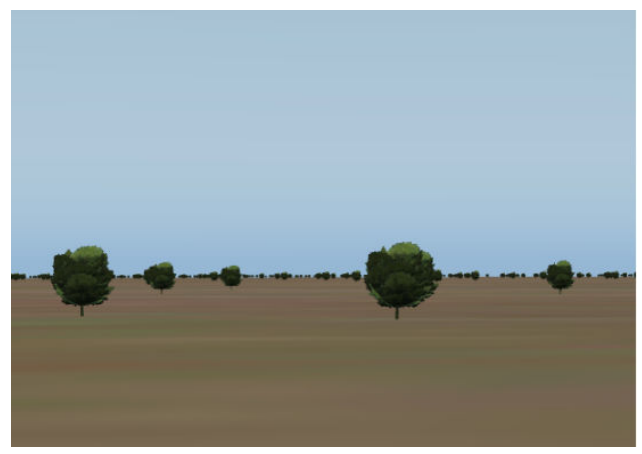

$5 m$

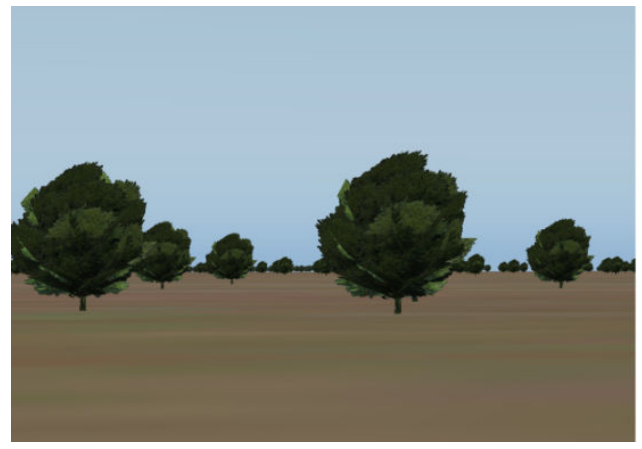

$10 \mathrm{~m}$

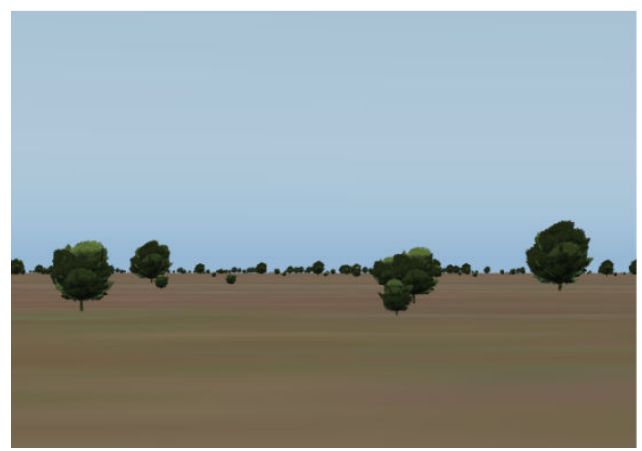

Mixture

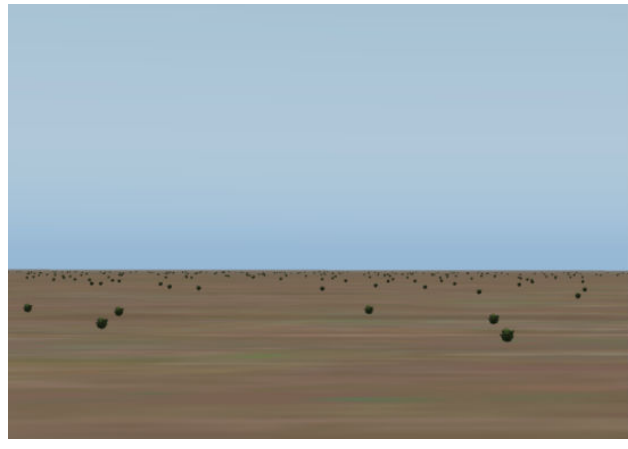

$2 m$

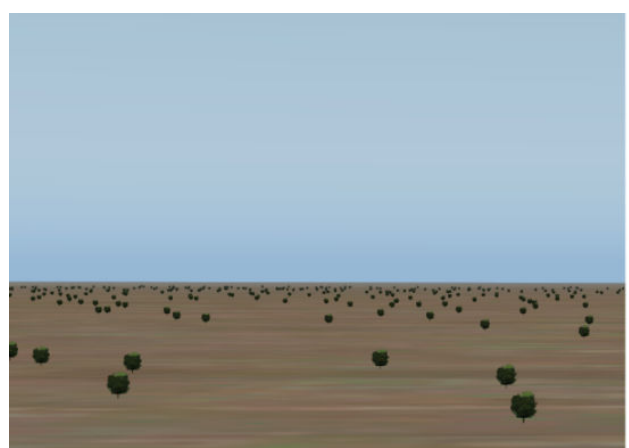

$5 m$

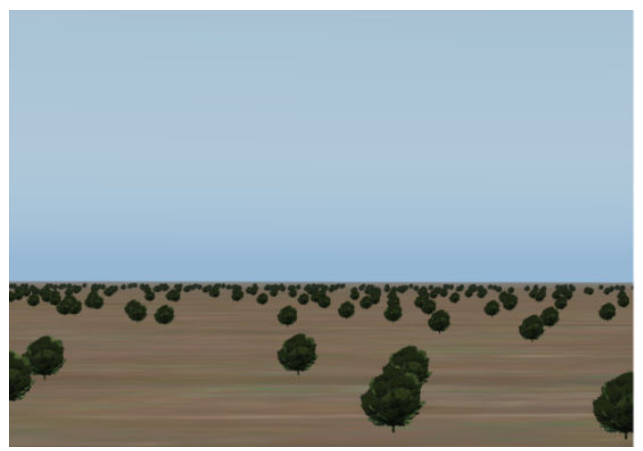

$10 \mathrm{~m}$

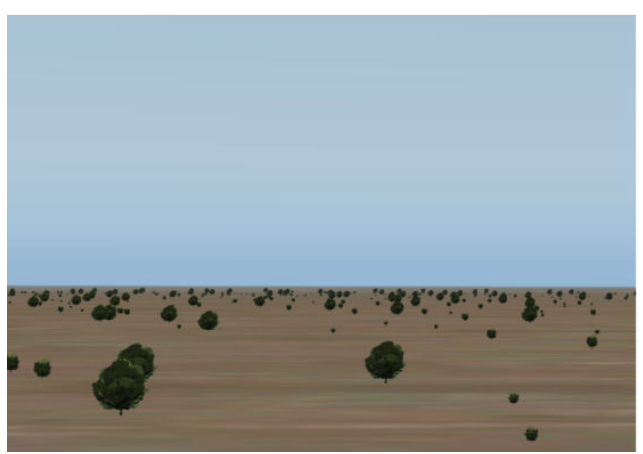

Mixture

Figure 10 Levels of Object Height for 144 objects per $\mathrm{km}^{2}$ 


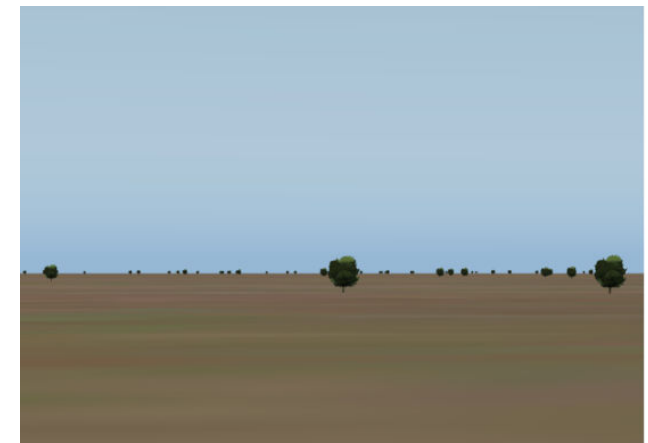

36 objects per $\mathrm{km}^{2}$

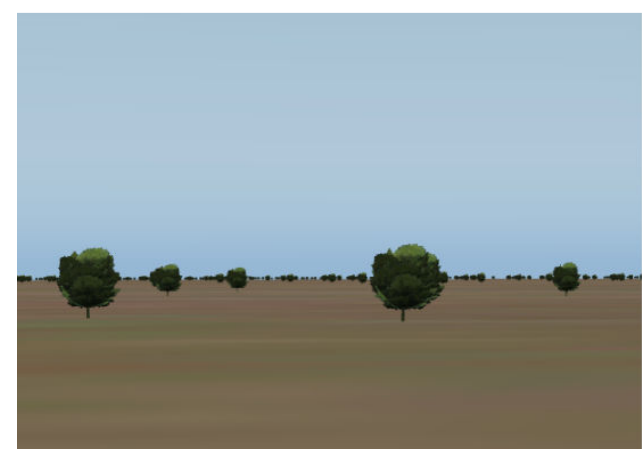

144 objects per $\mathrm{km}^{2}$

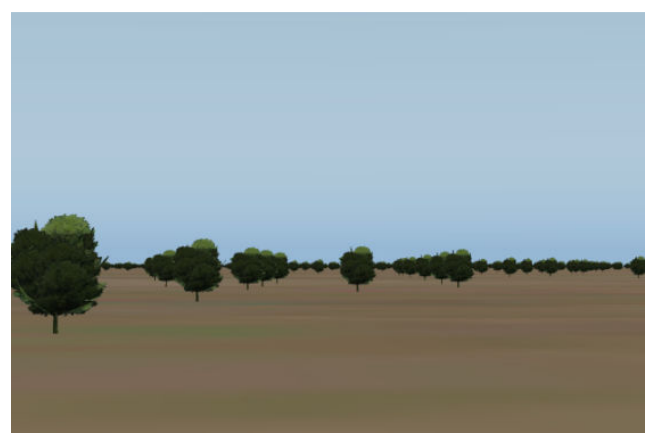

576 objects per $\mathrm{km}^{2}$

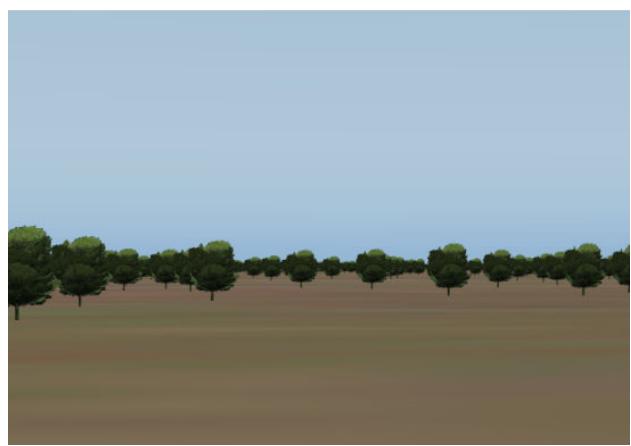

1296 objects per $\mathrm{km}^{2}$

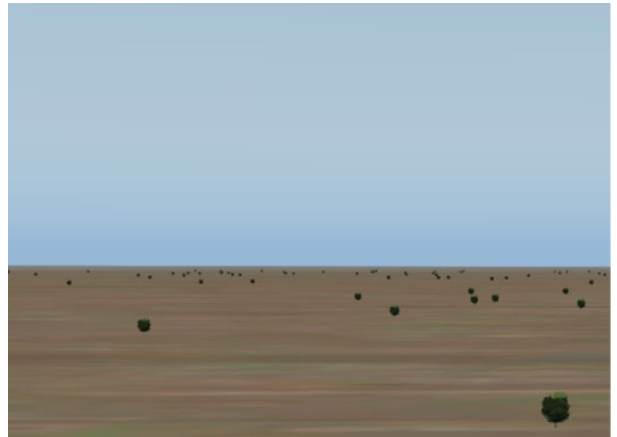

36 objects per $\mathrm{km}^{2}$

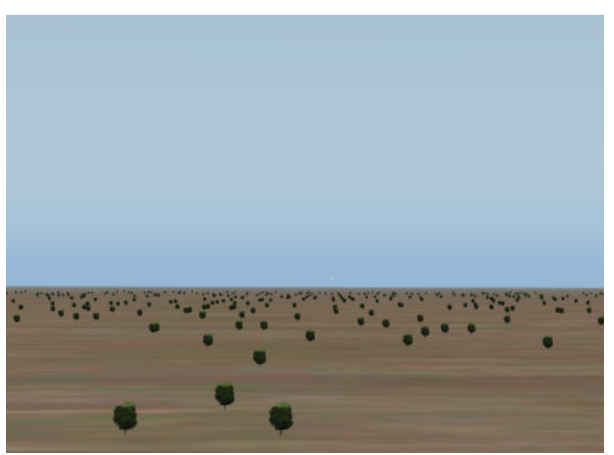

144 objects per $\mathrm{km}^{2}$

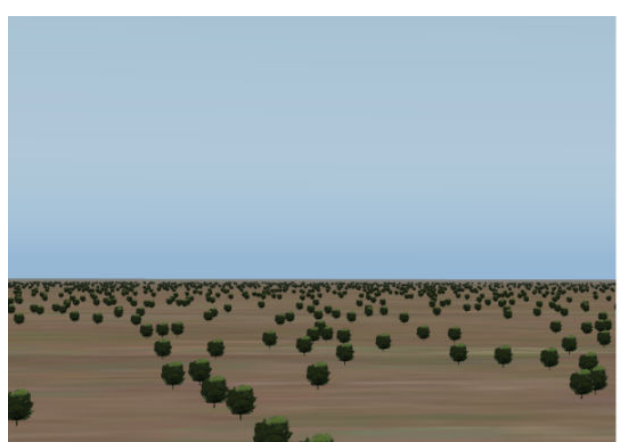

576 objects per $\mathrm{km}^{2}$

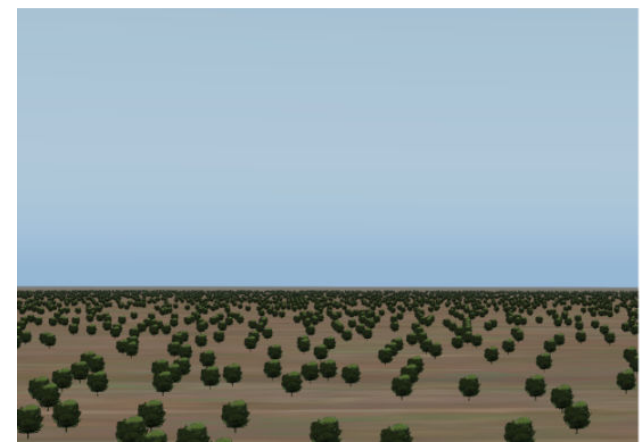

1296 objects per $\mathrm{km}^{2}$

Figure 11 Levels of Object Density for $5 \mathrm{~m}$ height objects 
There were two factors that were held-constant; terrain shape and shading. Kleiss \& Hubbard (1995) and Karaahmetoğlu et al. (2006) found that terrain shape has an effect on altitude control. Also, Lemos et al. (2003) stated that shading affected the horizontal stabilization. There are two choices for the factors that are effective on stabilization performance. First, they can be added to the experiment as a new factor and their interaction with 3D objects on stabilization performance can be investigated. Second, these factors can be removed from the experiment to avoid their interaction with 3D objects on stabilization performance. If the first option was chosen, the total number of runs of the experiment would increase formidably, so we only used flat terrain with no shading option.

\subsection{Response Variables}

Response variables were different for hover and low altitude flight. Table 5 lists the variables corresponding to each flight type.

Table 5 Response Variables

\begin{tabular}{ll}
\hline Flight Type & Variable \\
\hline \multirow{3}{*}{ Hover } & Distance Travelled \\
& Altitude Travelled \\
& Pilot Score of the Scene \\
Low Altitude Flight & Distance Travelled \\
& $\begin{array}{l}\text { Altitude Travelled } \\
\text { Pilot Score of the Scene }\end{array}$ \\
& Speed \\
\hline
\end{tabular}

\subsection{Procedure}

Experiment had four phases: pre-brief, familiarization, data collection and de-brief phases.

Pre-brief had two steps. At the first step, subjects signed the consent form (Appendix C). This form includes purpose of the experiment and short information about the procedure of the experiment. At the second step, subjects filled the pre-questionnaire which specifies gender, age, total flight hours, last flight time, most frequently used helicopter type, 
simulator experience and idea about fidelity and usage areas of flight simulators (Appendix A).

Familiarization consisted of approximately ten minutes flight time on the simulator prior to data collection. The pilots started the experiment when they felt ready. Minimum familiarization time was 5 minutes and maximum was 19 minutes.

Each run had two parts; hovering and low altitude flight. Before the each run, helicopter position was reset to the starting point.

In hovering part, data recording was initiated after subjects took off for hover. Distance travelled and altitude travelled data were recorded for a duration of two minutes. After 2 minutes the process was ended. Subjects ranked the scenery from 1 to 5 (best to worst) according to suitability for hover.

For low altitude flight part, the data recording was initiated after subject took off for low altitude flight. Distance travelled, altitude travelled, speed and orientation of helicopter were recorded. Process was ended when subjects said that the displacement was $2 \mathrm{~km}$. Subject ranked the scenery from 1 to 5 (best to worst) according to suitability for low altitude flight and estimated the speed of the flight. These two parts were repeated for all 16 combinations ( 4 density* 4 height).

De-brief consisted of post-questionnaire and de-brief information form (Appendix B, Appendix D). Pos-questionnaire form included the idea of the participants about the Pcbased simulator used in the experiment and performance in terms of ability to control the helicopter. De-brief information form included aim of the study and contact information for more details and results. 


\section{CHAPTER 4}

\section{EXPERIMENT RESULTS}

In this chapter, the results of the experiment for determining the effect of 3D objects on hover and low altitude flight using the independent variables of 3D object height and object density are presented.

\subsection{Performance Measures}

Performance was measured according to the flight type: hover and low altitude flight. Performance measure of these flight types are explained below.

\subsubsection{Hovering:}

In each treatment, vertical and horizontal position of the helicopter was recorded at every second for two minutes. Positions at 1-second, 5-second and 10-second intervals were calculated by averaging the data points. Two measures, Distance Travelled (DT) and Altitude Travelled (AT) were calculated for hover. Distances between averaged points were summed as Distance Travelled (DT) (Figure 12). Altitude Travelled (AT) data was calculated by summing absolute values of the distance between averaged points (Figure 13). A result for three different durations was compared to see if they differed. No significant difference was detected. Therefore, 5-second interval was chosen for duration of averaging. 


\subsubsection{Low Altitude Flight:}

In each treatment, vertical position, horizontal position, and speed of flight were recorded at every second until the participant stated that displacement was $2 \mathrm{~km}$. Distance Estimation Error(DEE), Distance Travelled(DT), Altitude Travelled(AT) and Speed Estimation Error(SEE) were calculated as performance measures of low altitude flight.

Distance between start and end point was used to calculate how far the participants flied. Then $2000 \mathrm{~m}$ was subtracted from the distance and its absolute value was named as DEE. AT was calculated for the altitude data that were above the $1 / 2 *$ Maximum Altitude for each run. The mean of the altitudes that were above the $1 / 2 *$ Maximum Altitude was subtracted from the altitude and absolute values were summed as AT. Absolute values of the difference between the speed estimated by the participants and the one calculated by XPlane data output was calculated as Speed Estimation Error (SEE).

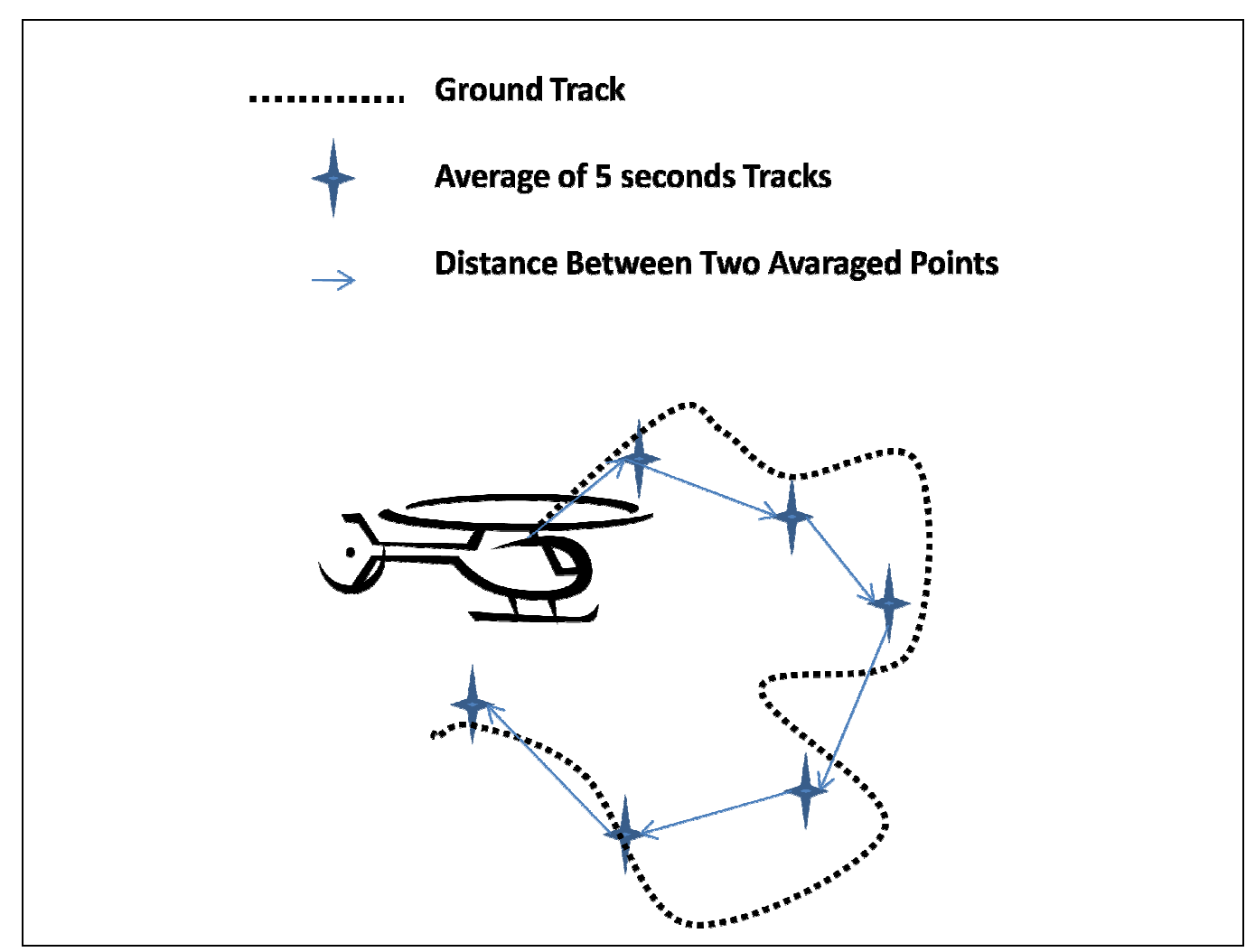

Figure 12 Calculation of Distance Traveled (DT) for Hover 


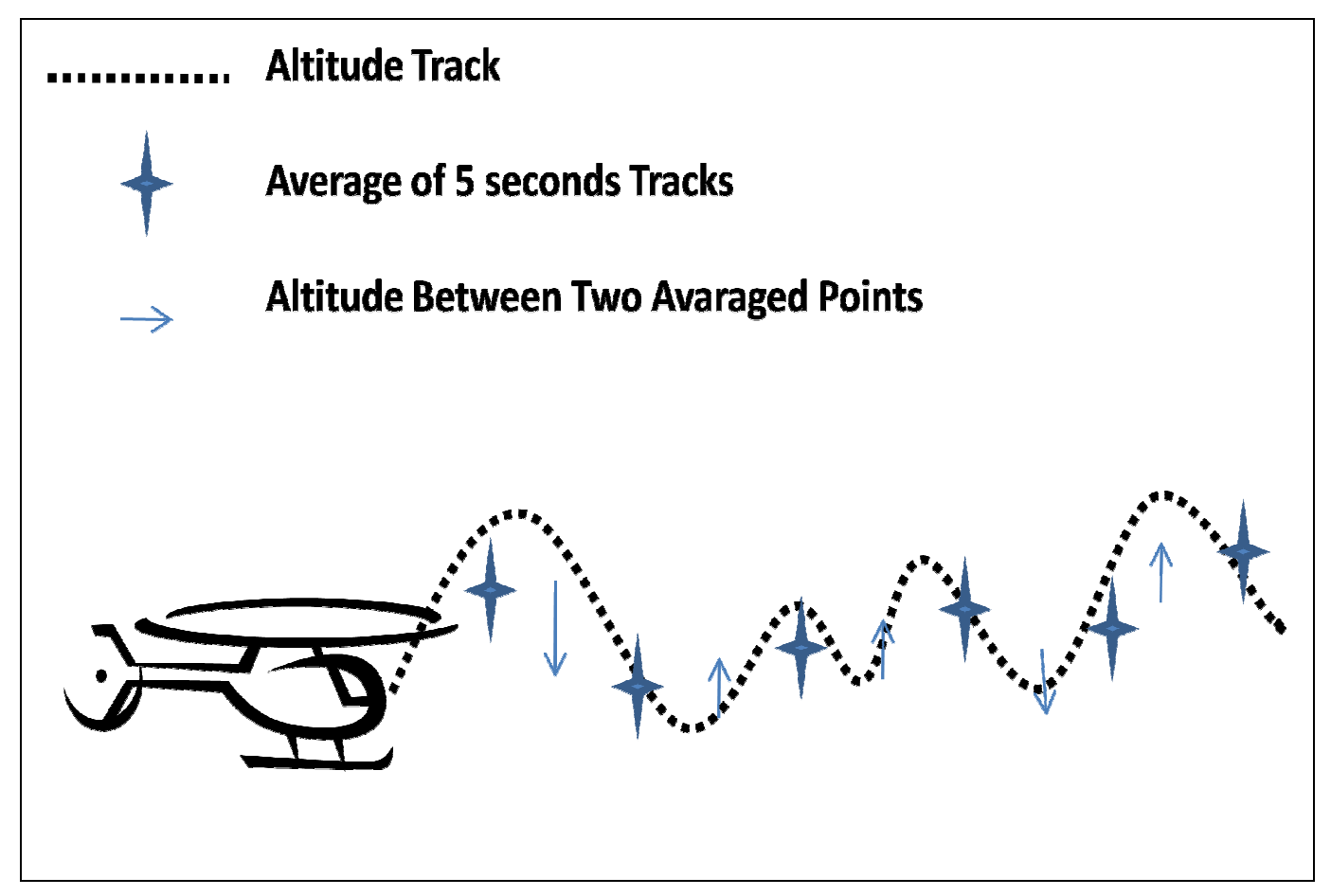

Figure 13 Calculation of Altitude Traveled (AT) for Hover

\subsection{Model}

The independent variables of the experiment were object density (4 levels) and object height ( 3 levels). There was also a fourth level for objects with a mixture of all three heights. Full-factorial design was used in design of experiment. Therefore, experiment consisted of 16 treatments (4 Object Density x 4 Object Height).

In order to eliminate the learning effect, randomized complete block design was used. 16 treatments were ordered randomly and each subject participated in each run once. The dependent variables were Distance Travelled (DT), Altitude travelled (AT) and speed.

Two analyses were done for all performance measures. First, 4 object density levels (36, 144,576 and 1296 objects per $\left.\mathrm{km}^{2}\right)$ and 3 object height levels $(2,5$ and $10 \mathrm{~m})$ were analyzed. In second analysis, mixture level of the object density is added to the object height levels. 
Four object density levels $\left(36,144,576\right.$ and 1296 objects per $\left.\mathrm{km}^{2}\right)$ and four object height levels $(2 \mathrm{~m}, 5 \mathrm{~m}$, mixture and $10 \mathrm{~m})$ were analyzed to detect the effect of mixture objects.

Fixed effect model was used because the effects of factors are assumed to be valid only for the levels selected.

$y_{i j k}=\mu+\lambda_{i}+\beta_{j}+(\lambda * \beta)_{i j}+\delta_{k}+\epsilon_{i j k}$

$\mathbf{y}_{\mathrm{ijk}}$ : Observed value of Response variable $\mathrm{y}$, at level $\mathrm{i}$ of Object Density, at level $\mathrm{j}$ of Object Height, at block k.

$\mu$ : Overall Mean

$\lambda_{\mathbf{i}}$ : Effect of Object Density at level $\mathbf{i}=1,2,3,4$

1: 36 objects per $\mathrm{km}^{2}$

2: 144 objects per $\mathrm{km}^{2}$

3: 576 objects per $\mathrm{km}^{2}$

4: 1296 objects per $\mathrm{km}^{2}$

$\boldsymbol{\beta}_{\mathrm{j}}$ : Effect of Object Height at level $\mathrm{j}=1,2,3,4$

1: $2 \mathrm{~m}$

2: $5 \mathrm{~m}$

3: $10 \mathrm{~m}$

4: mixture

$\left(\lambda^{*} \beta\right)_{\mathrm{ij}}$ : Effect of Interaction between level $\mathrm{i}$ of Object Density and level $\mathrm{j}$ of Object Height

$\boldsymbol{\delta}_{\mathbf{k}}$ : Effect of Block (Subject) $\mathbf{k}=1,2,3, \ldots . ., 10$

$\epsilon_{\mathrm{ijk}}$ : Random Error NID $\left(0, \sigma^{2}\right)$

For all performance measures, first the learning effect on the related flight task was investigated. Second, ANOVA was conducted on the related factors. Then, the effect size was calculated and a post-power analysis was conducted to check if the data size was sufficient enough to reject the null hypothesis.

G-Power version 3.0.10 was used to calculate the achieved power (Faul, Erdfelder, Lang, \& Buchner). For ANOVA: main effects and interactions a post-hoc analysis was done. The 
required parameters to calculate the power level were effect size, significance level and total sample size.

The abbreviations below are used for reporting the power analysis results:

$f=$ Effect size

$\alpha=$ Significance level

$\mathrm{N}=$ Total sample size

\section{Power Level (PV):}

Power refers to the probability that statistically significant difference is found by the experimenter when a difference really exists (Miller, Daly, Wood, Roper and Brooks).

There is no strict rule for determining the required power for the experiment: 0.80 or above power is generally accepted. Therefore, we set the required power level to 0.80 that refers to $80 \%$ or greater chance of finding a statistically significant difference when there is one(Murphy, K. R., \& Myors, B.).

\section{Effect Size (f):}

The effect size is the degree to which the phenomenon under experiment is present in the population. Therefore, if the effect size increases the degree a phenomenon is likely to be detected and null hypothesis rejected also increases (Miller et al.). Effect size is grouped into three levels: Large: $>0.50$, Medium: $>0.30$ and Small: $>0.10$.

\section{Significance Level $(\alpha)$ :}

Significance level of this experiment was set to 0.05 .

\section{Total Sample Size (N):}

If the mixture level was included to the object density level total sample size was 160 . Otherwise, task involves 120 samples.

\subsection{Learning Effect for Hover}

To verify the randomization successfully eliminated the learning effect, an ANOVA (Analysis of Variance) was conducted for Run Order (within block) for its effect on DT and AT with the result presented in Table 14 and Table 15 (in the Appendix).

The order effect P-Value of 0.526 indicates there was no influence of order of the treatment. Also main effects plot for DT (Figure 14) indicates the absence of learning effect. 
There was no influence of order of the treatment $(p=0.341, \alpha=0.05)$ AT performance. Main effects plot for AT (Figure 15) is consistent with the absence of learning effect.

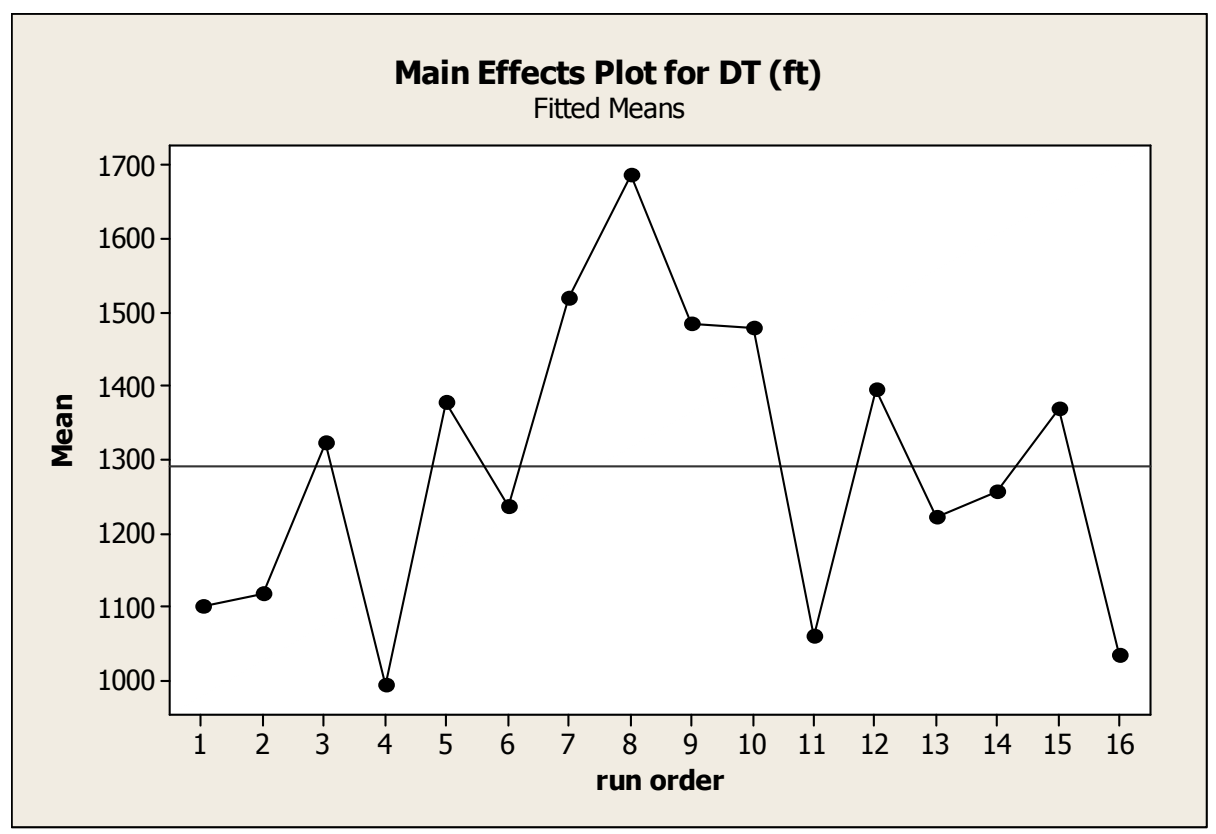

Figure 14 Hover: Main Effects of Run Order (With in Subjects) on DT

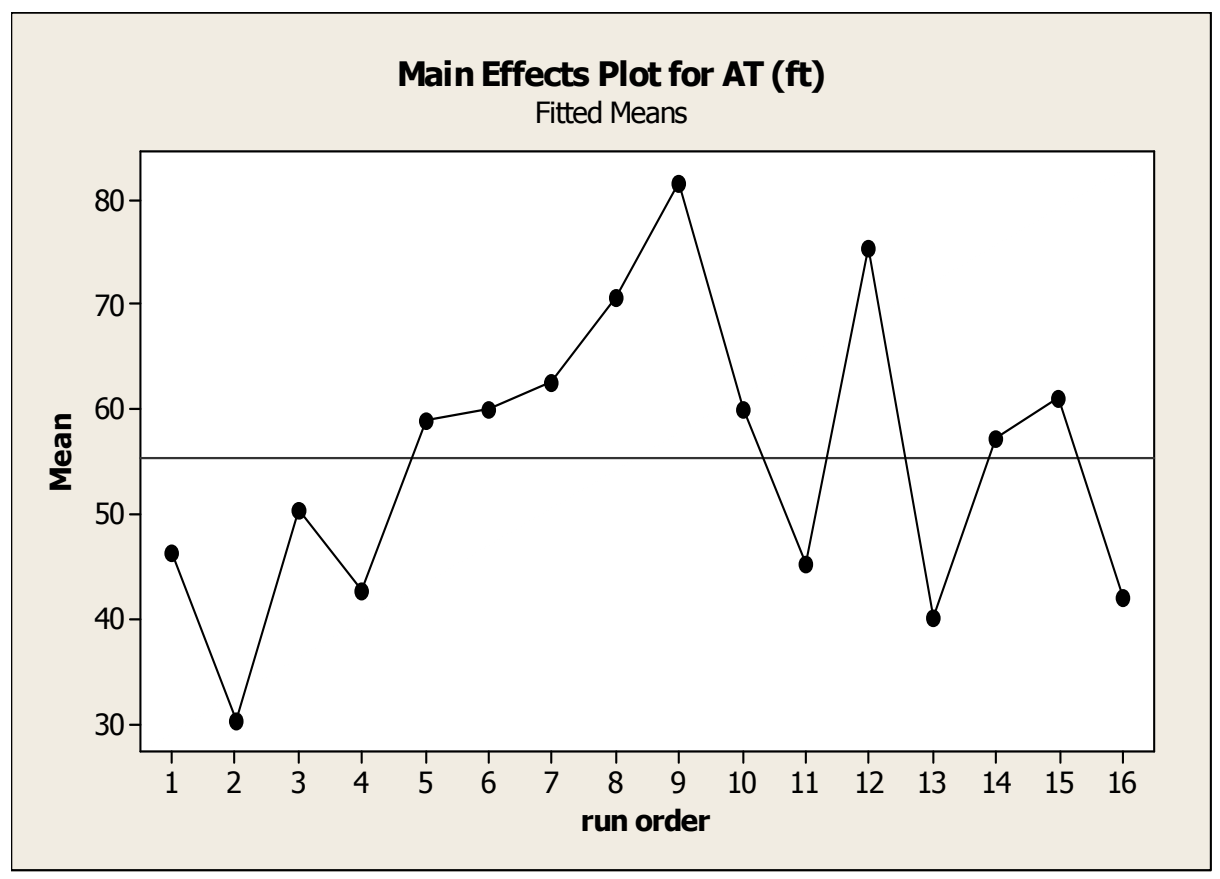

Figure 15 Hover: Main Effects of Run Order (With in Subjects) on AT 


\subsection{Horizontal Hovering Performance}

To investigate the effect of object density and object height on horizontal hovering performance, distance travelled data was analyzed.

\subsubsection{Model Adequacy:}

Analyzing the data for no differences in treatment means by using the ANOVA requires the satisfaction of these assumptions:

- The errors are normally distributed with mean zero.

- The error variance does not change for different levels of a factor or according to the values of the predicted response.

- Each error is independent of all other errors. (Montgomery, 1996)

If the model violates these assumptions, the results of the analysis can be misleading. Also, this violation leads to incorrect $p$-values.

Residuals are the standard examination way for violations of the basic assumptions and model adequacy. The residual for observation $\mathrm{k}$ in treatment ij was defined as:

$$
\begin{array}{ll}
\text { Fitted Value: } & \hat{y}_{\mathrm{ijk}=} \mu+\lambda_{\mathrm{i}}+\beta_{\mathrm{j}}+(\lambda * \beta)_{\mathrm{ij}}+\delta_{\mathrm{k}} \\
\text { Observed Value: } & \mathrm{y}_{\mathrm{ijk}}=\mu+\lambda_{\mathrm{i}}+\beta_{\mathrm{j}}+(\lambda * \beta)_{\mathrm{ij}}+\delta_{\mathrm{k}}+\epsilon_{\mathrm{ijk}} \\
\text { Residual: } & \mathrm{e}_{\mathrm{ijkn}=y_{\mathrm{ijk}}-\hat{y}_{\mathrm{ijk}}}
\end{array}
$$

In adequate models, residuals do not follow an obvious pattern. Also, they should have no structure. The residual plot of horizontal hovering performance is presented in the Figure 16-19. Other residual plots are given in the Appendix F.

Distance Travelled (DT) data of 4(object density)*3 (object height) treatments was analyzed to assess the normality assumption for ANOVA. As shown in Figure 16, normal probability plot of distance travelled data was skewed and indicating a violation of normality. 
In the fixed effect analysis of variance, little drift from normality is not a serious problem. However, an error distribution that has a pattern like a funnel is more important than a skewed distribution. ANOVA is robust to the normality assumption as the $\mathrm{F}$ test which is the basis for ANOVA is only slightly affected by nonnormality (Montgomery, 1996).

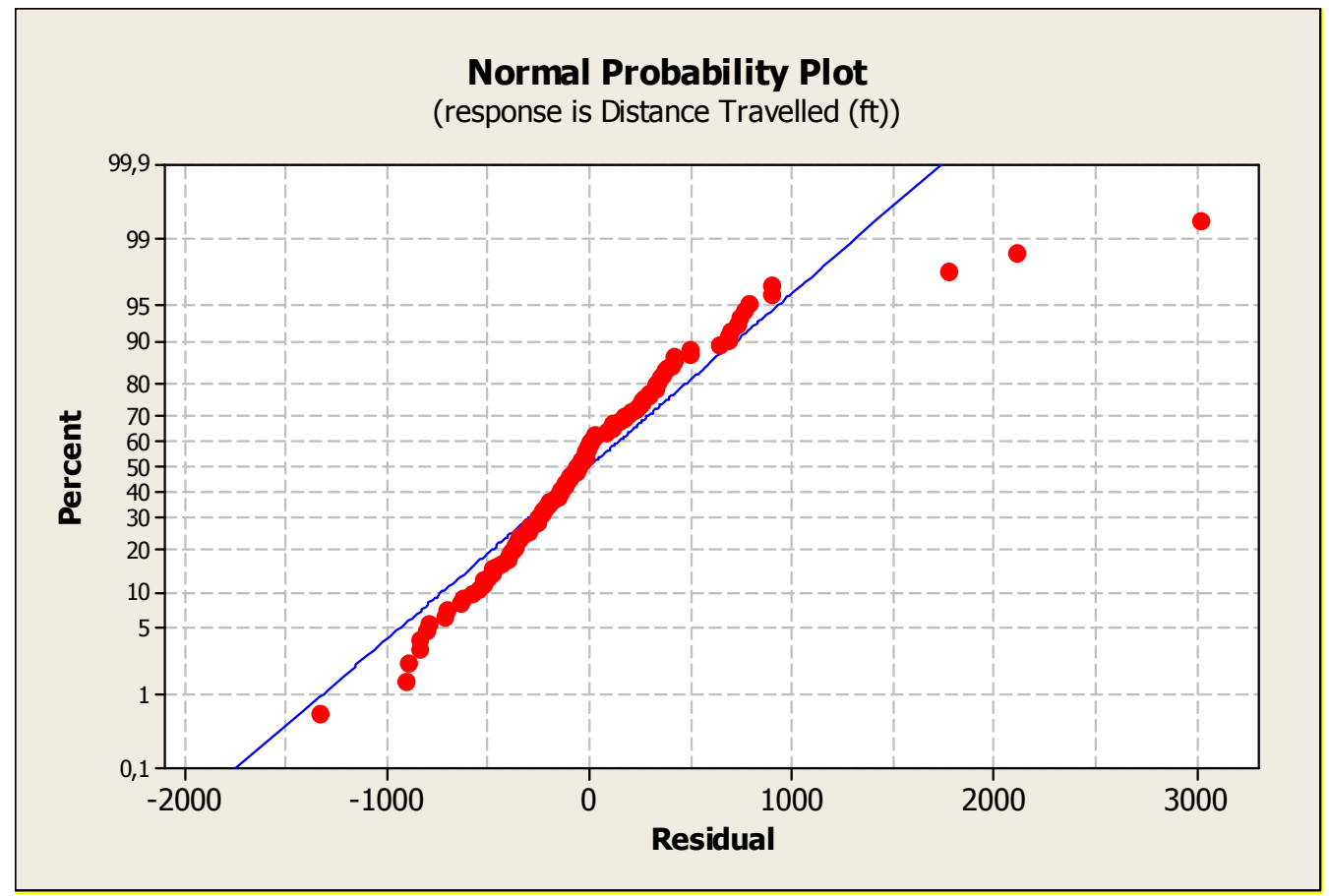

Figure 16 Hover: Normal Probability Plot of Residuals for DT (4 Object Density *3 Object Size)

In order to check the independency assumption of ANOVA, residuals versus order of data for Distance Travelled was analyzed. As shown in Figure 17, they did not follow a pattern. Therefore, independency assumption of ANOVA was satisfied.

One of the assumptions of regression and ANOVA is that the variance of the error term is constant. In the residual versus the fitted values plot, the errors would have constant variance if the residuals are scattered randomly around zero. If the residuals increase or decrease with the fitted values in a pattern that look likes a funnel, the errors may not have constant variance. 


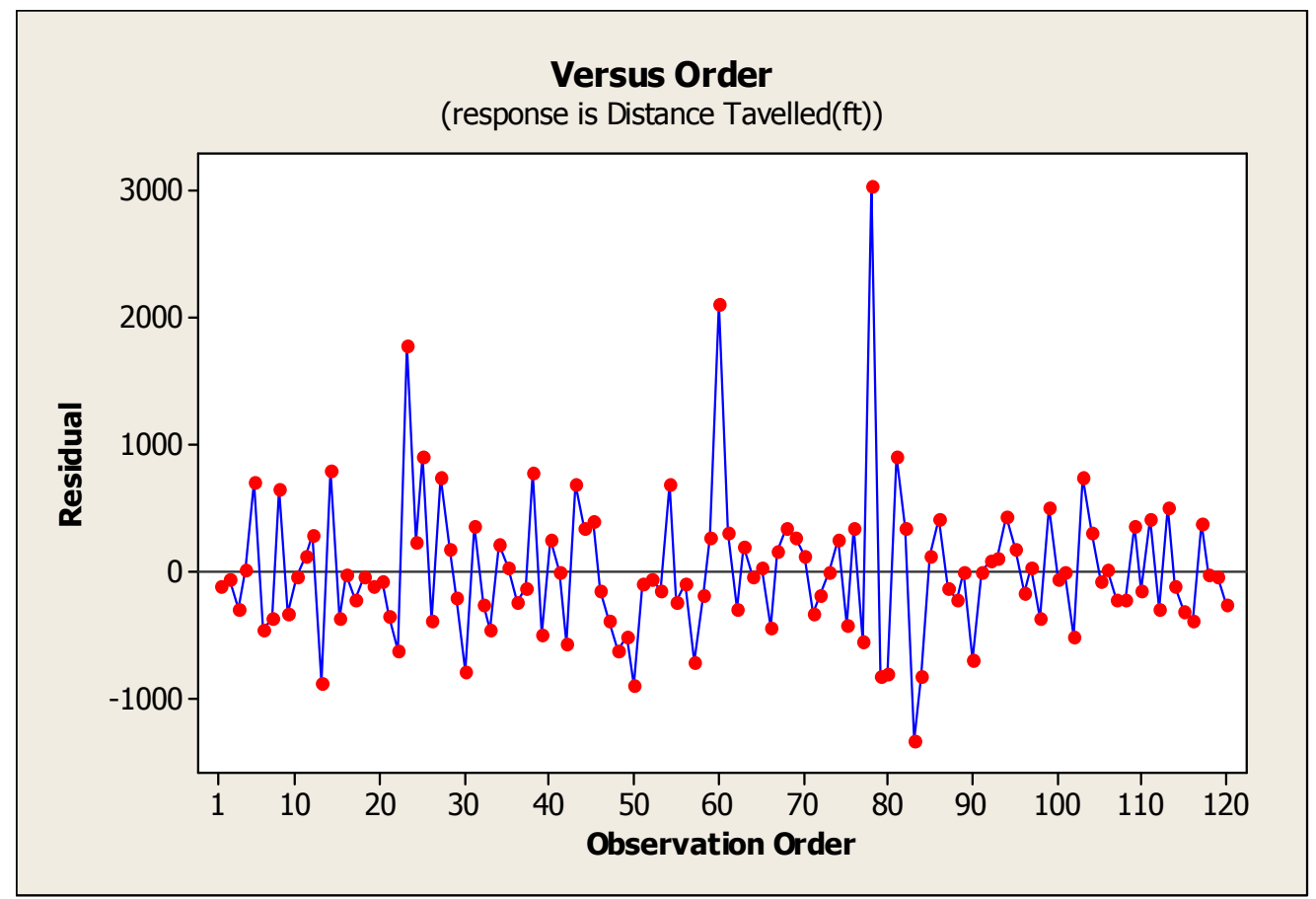

Figure 17 Hover: Residuals versus the Order of the Data for DT (4 Object Density *3 Object Size)

The variance of the residuals increases with the fitted values (Figure 18). Notice that as the fitted value increases, there is a wider scatter of the residuals indicating unequal variances. This pattern suggests that the error variance increases as the mean increases. A transformation of the data can help stabilize these variances. Montgomery (1996) rectified a method and gave a table for selecting the proper variance stabilizing transformation. They were used while selecting the form of the transformation for each performance. Logarithm transformation was suitable for the DT data. As shown in Figure 19, taking the logarithm of DT solved the problem. It reduced the skew and stabilized variance assumption was satisfied as shown in Figure 19.

In addition, DT data of the 4 (object density)* 4 (object height) treatments was analyzed to assess the normality assumption for an ANOVA (Figure 51 in the Appendix). Normal probability of distance travelled data was skewed and not normally distributed. Also, residuals versus order of data for Distance Travelled did not follow a pattern. Therefore, independency assumption of ANOVA was satisfied. 
The variance of the residuals increases with the fitted values. This pattern suggests that the error variance increases as the mean increases. Taking the logarithm of DT solved the problem (Figure 52 in the Appendix).

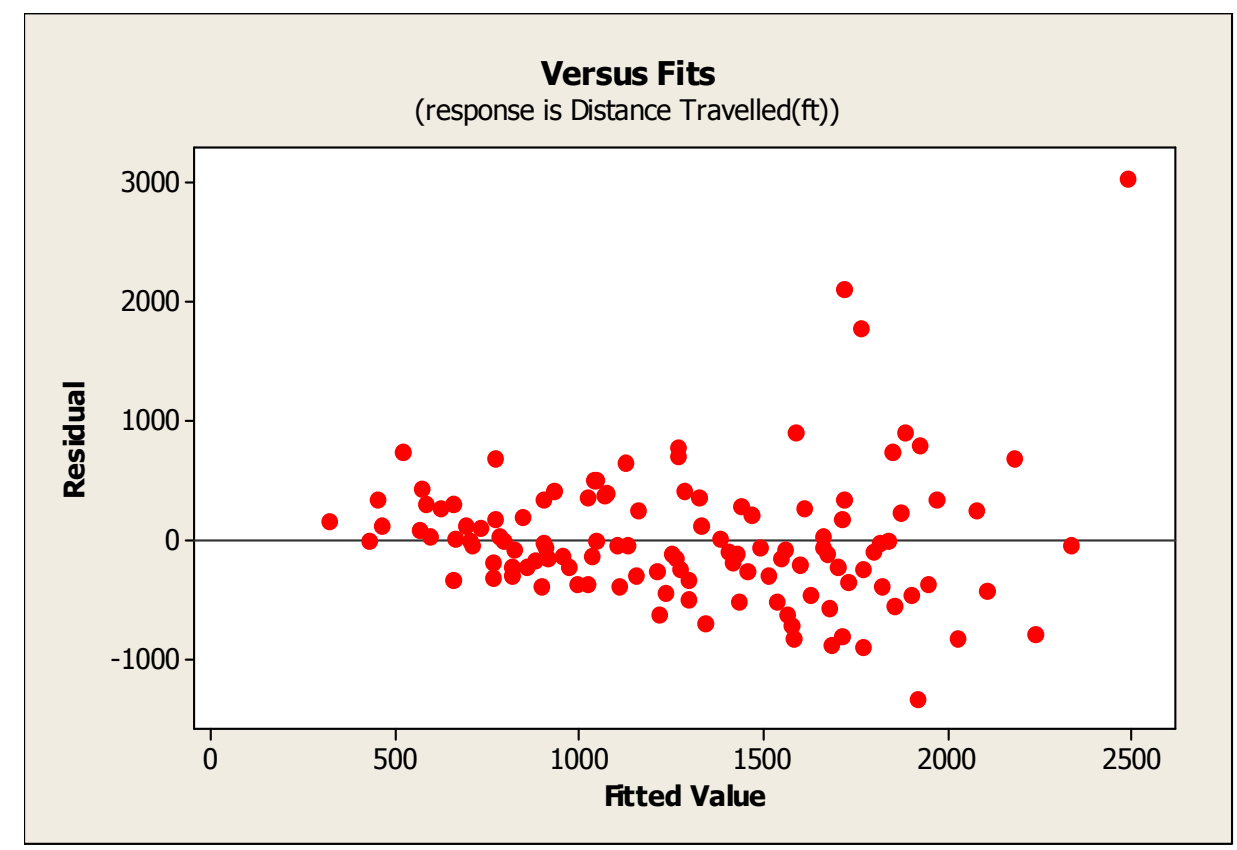

Figure 18 Hover: Residuals versus the Fitted Values for DT (4 Object Density *3 Object Size)

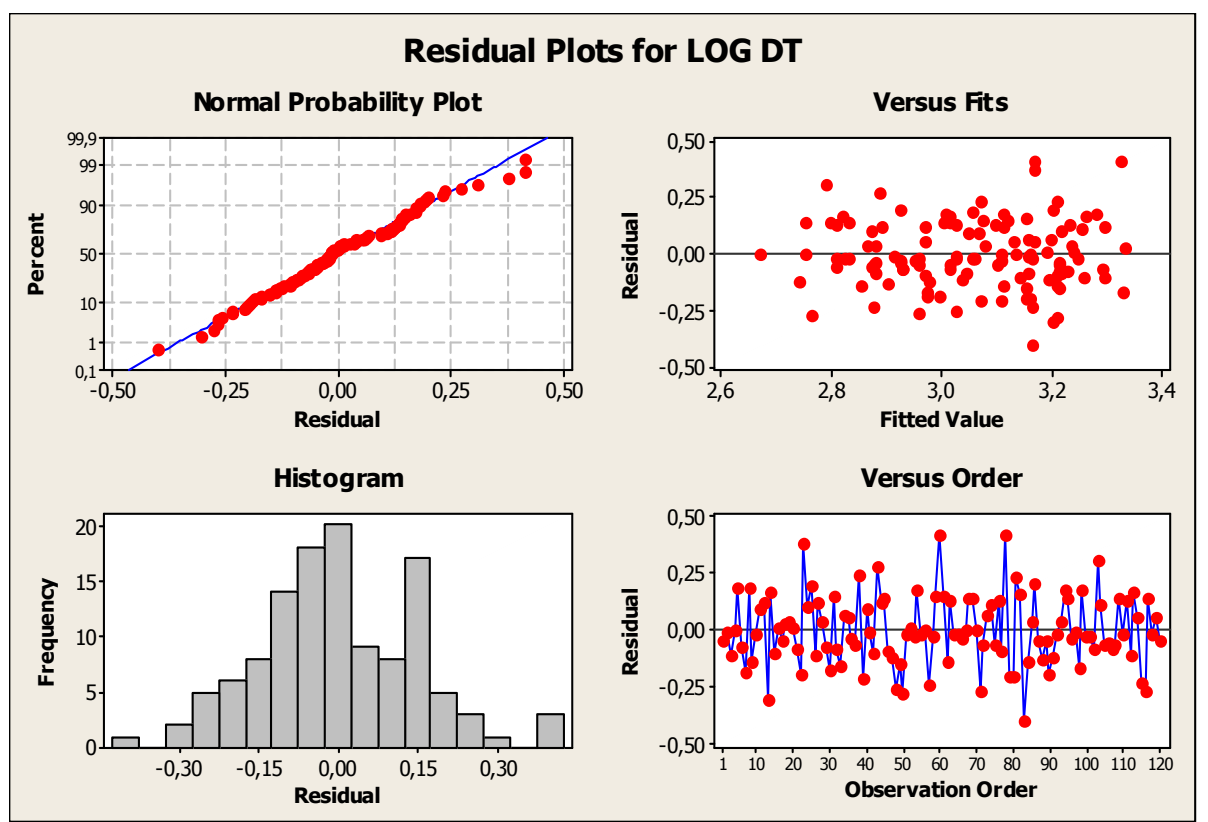

Figure 19 Hover: Residual Plots for LOG DT (4 Object Density *3 Object Size) 


\subsubsection{Results}

An ANOVA comparison was conducted on the factors Subject, Object Density (4 levels) and Object Height ( 3 level) on LOGDT and the results are presented in Table 16 in the Appendix. Object density ( $p=0.026, \alpha=0.05)$ and object height $(p=0.047, \alpha=0.05)$ have significant effects on DT performance.

In order to determine the power of the object density and object height, first effect size was calculated. Object density $(f=0.33)$ and object height $(f=0.39)$ have medium to large effect size. Power of the object density is 0.86 and object height is 0.98 (at $\alpha=0.05$ and $\mathrm{N}=120$ ). These power results show that it is unlikely that we falsely detected a significant difference.

It was shown in main effects plot in Figure 20 that when the object height increased, DT performance of the participant decreased. Best object height for horizontal hover performance was $2 \mathrm{~m}$, second was $5 \mathrm{~m}$ and last was $10 \mathrm{~m}$ object. As for object density, 576 and 1296 objects per $\mathrm{km}^{2}$ had better effect on DT than 36 and 144 objects per $\mathrm{km}^{2}$. Best object density for DT performance was 576 objects per $\mathrm{km}^{2}$ (Figure 20). After that point increasing the object density decreased the performance.

Although object density and object height had significant effects on DT performance of participants, their interaction was not significant (object density* object height, $p=0.937$, $\alpha=0.05)$. This result is also confirmed by interaction plot (Figure 21 ).

Result of this experiment in terms of horizontal hovering performance is consistent with the result of Peitso (2002). Both of them state that object density has a significant effect on horizontal hovering performance. However, in Peitso (2002) the performance was highest with maximum density $\left(\% 1 \approx 10000\right.$ objects per $\mathrm{km}^{2}$, object height $\left.\approx 50 \mathrm{~cm}\right)$ and lowest with minimum density $(\% 0)$ and there was no peak point. 


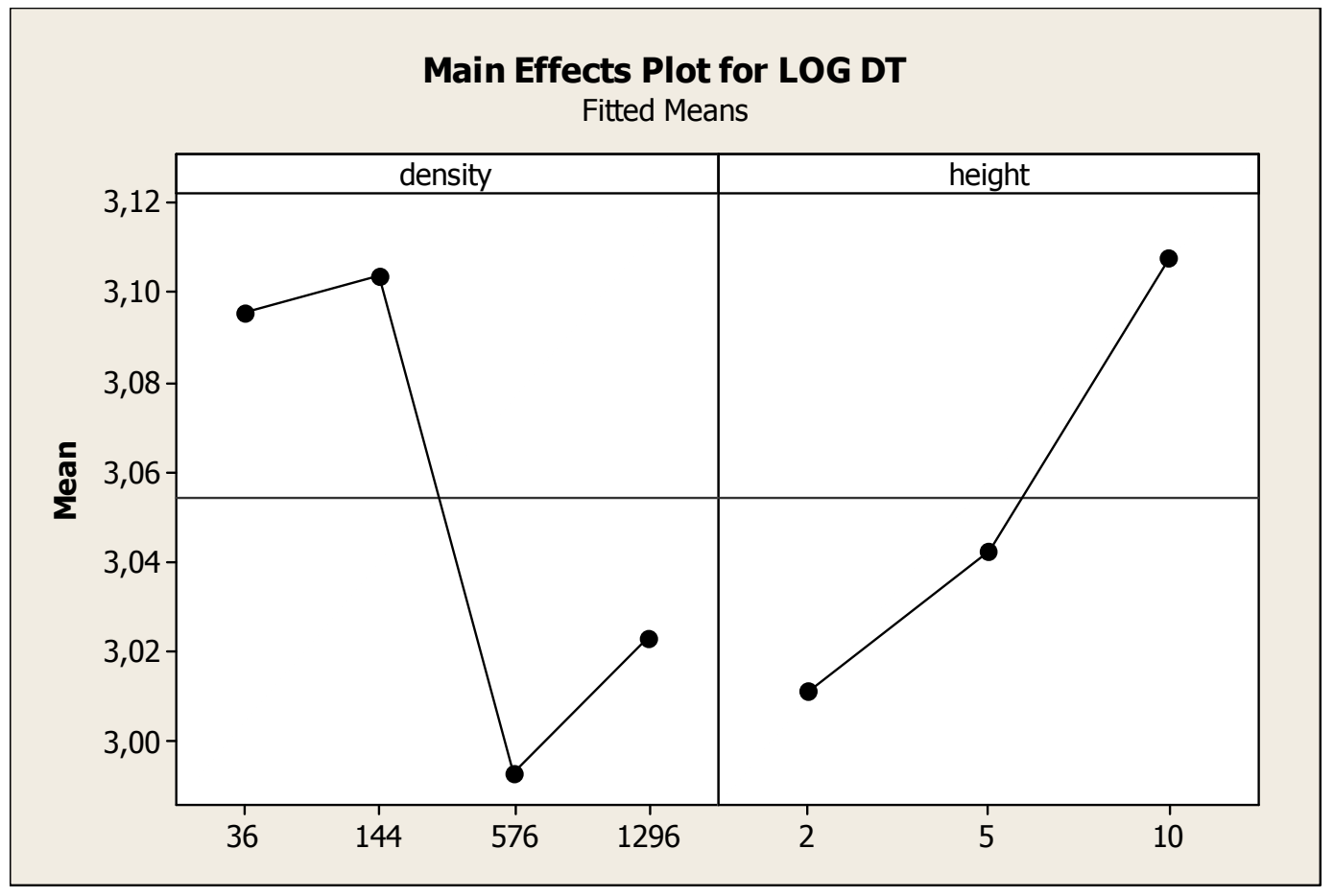

Figure 20 Hover: Main Effects Plot for LOG DT versus Object Height (3 levels), Object Density (4 levels)

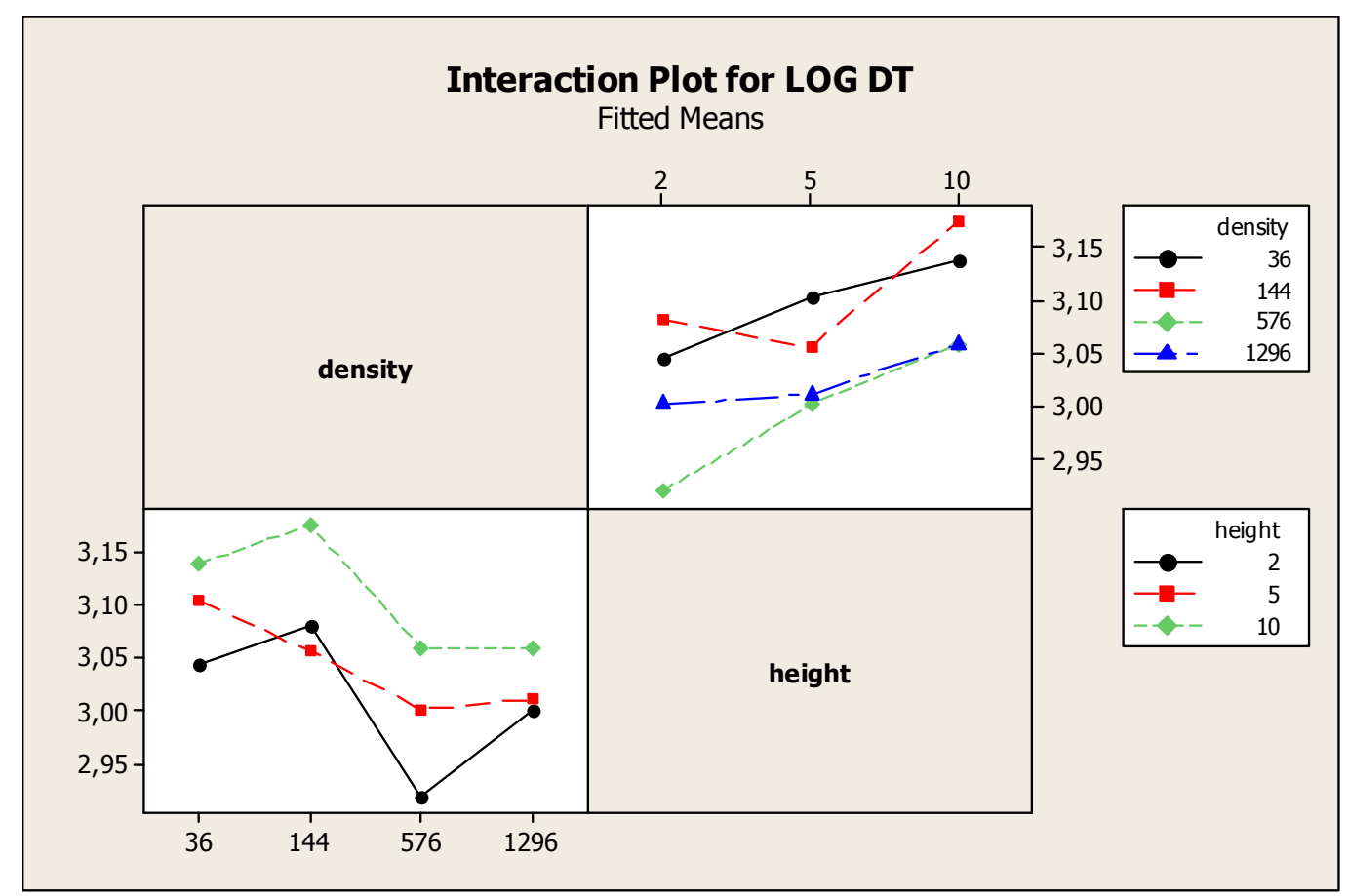

Figure 21 Hover: Interaction Plot for LOG DT versus Object Height (3 levels), Object Density (4 levels) 
In order to analyze the effect of mixture level of object height factor, another ANOVA comparison was conducted on the factors Subject, Object Density (4 levels) and Object height (4 level) on LOGDT and the results are presented in Table 17 in the Appendix.

Object density ( $p=0.148, \alpha=0.05$ ) and object height ( $p=0.116, \alpha=0.05$ ) have no significant effects on DT performance when mixture level was added to the object height levels. The object used in mixture level combined of $2 \mathrm{~m}, 5 \mathrm{~m}$ and $10 \mathrm{~m}$ objects and their mean height was $5.66 \mathrm{~m}$. Therefore, it is not surprising that the mixture level performance was similar to $5 \mathrm{~m}$ level. Also, interaction of object density and object height was not significant (object density* object height, $p=0.937, \alpha=0.05$ ) (Figure 23).

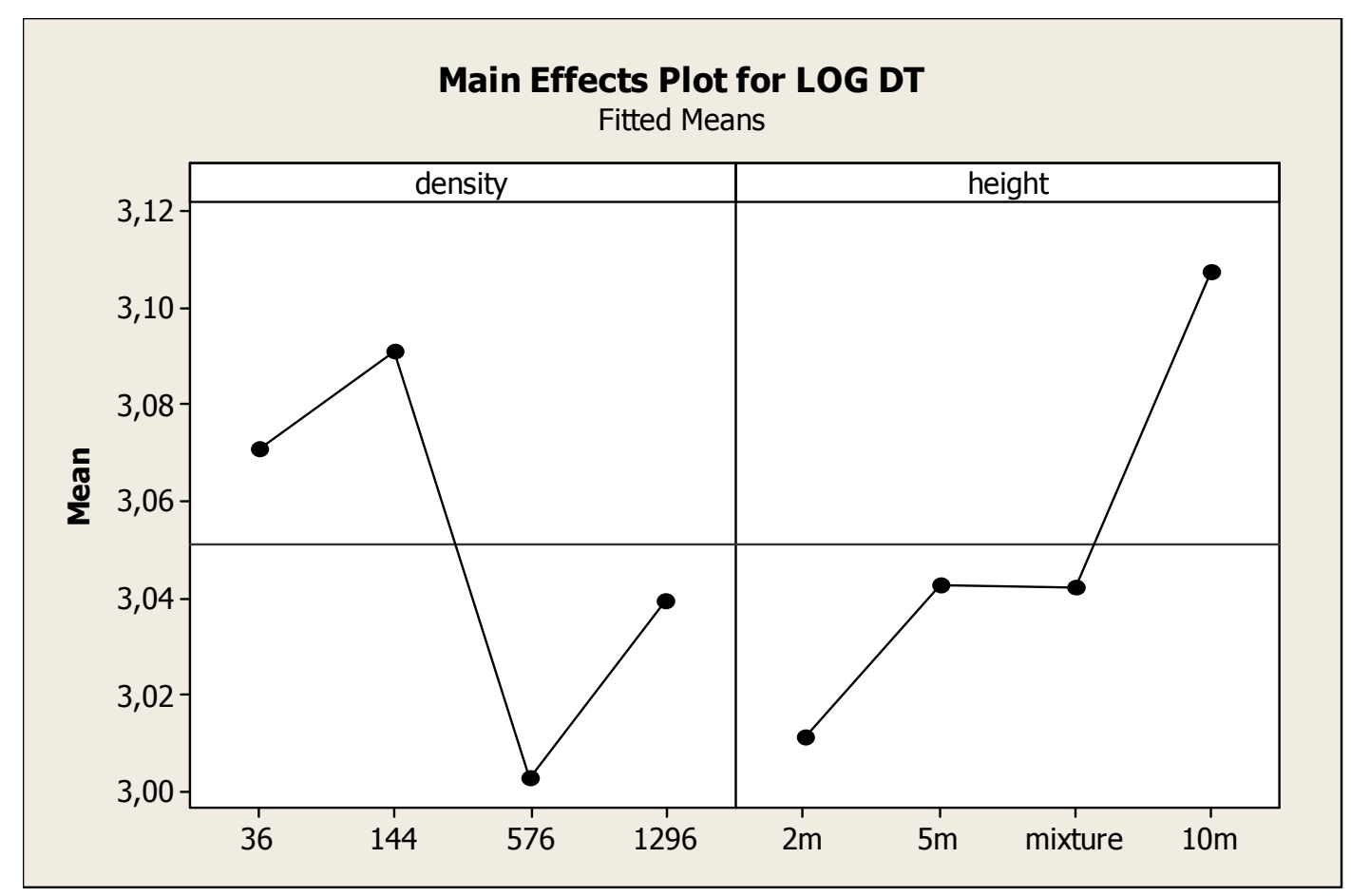

Figure 22 Hover: Main Effects Plot for LOG DT versus Object Height (4 levels), Object Density (4 levels) 


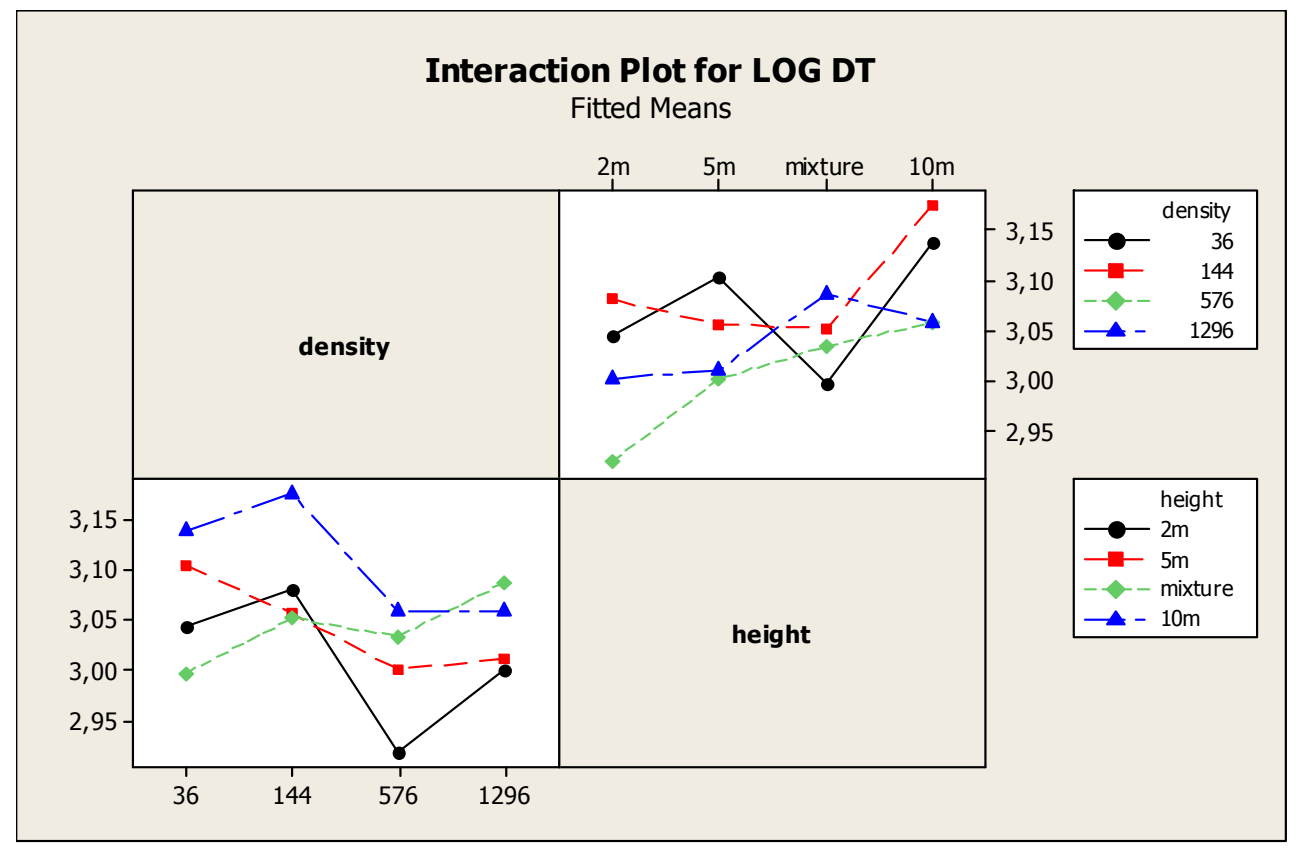

Figure 23 Hover: Interaction Effects Plot for LOG DT versus Object Height (4 levels), Object Density (4 levels)

\subsection{Vertical Hovering Performance}

In order to clarify the effect of object density and object height on vertical hovering performance, altitude travelled data was analyzed.

\subsubsection{Model Adequacy}

Same as with the model adequacy of the horizontal hovering performance, the AT data for 4 (object density)*3(object height) levels was analyzed in terms of normality, independency and pattern of the error. The normal probability plot of the AT data was skewed and not normally distributed (Figure 53 in the Appendix). Independency assumption was checked on residuals versus order of the data and it was satisfied.

The variance of the residuals increases with the fitted values (Figure 53 in the Appendix). This pattern suggests that the error variance increases as the mean increases. Again a logarithmic transformation of the data was used to stabilize these variances (Figure 54 in the Appendix). 
Moreover, AT data of 4 (object density)* 4 (object height) treatments was analyzed. Normal probability of AT data was skewed and not normally distributed (Figure 55 in the Appendix). Also, residuals versus order of data of AT did not follow a pattern. Therefore, independency assumption of ANOVA was satisfied. The variance of the residuals increases with the fitted values. The logarithm of AT was taken to solve the problem (Figure 56 in the Appendix).

Unless otherwise specified, same procedure is carried out for the model adequacy of other performance measures. Performance data was transformed according to the variance stabilizing transformation table of Montgomery (1996).

\subsubsection{Results}

An ANOVA comparison was conducted on the factors Subject, Object Density and Object Height on log AT (Table 18 in the Appendix). The object density ( $p=0.030, \alpha=0.05)$ and object height ( $p=0.000, \alpha=0.05$ ) have significant effects on vertical hovering performance. Object density ( $f=0.32$ ) has medium effect size and object height ( $f=0.58$ ) has large effect size. Power of the object density is 0.84 and object height is 0.99 (at $\alpha=0.05$ and $N=120$ ). These power results show that it is unlikely that we falsely detected a significant difference.

It was shown in main effects plot in Figure 24 that when the object height increased, vertical hovering performance of the participant decreased. Best object height was $2 \mathrm{~m}$, second was $5 \mathrm{~m}$ and last was $10 \mathrm{~m}$ object. As for density, 576 and 1296 objects per km² had better effect on AT than 36 and 144 objects per $\mathrm{km}^{2}$. Best object density for AT performance was 576 objects per $\mathrm{km}^{2}$ (Figure 24).

Although object density and object height had significant effects on vertical hovering performance of participants, their interaction was not significant (object density* object height, $p=0.148, \alpha=0.05$ ). This result also confirmed by interaction plot (Figure 25 ). 


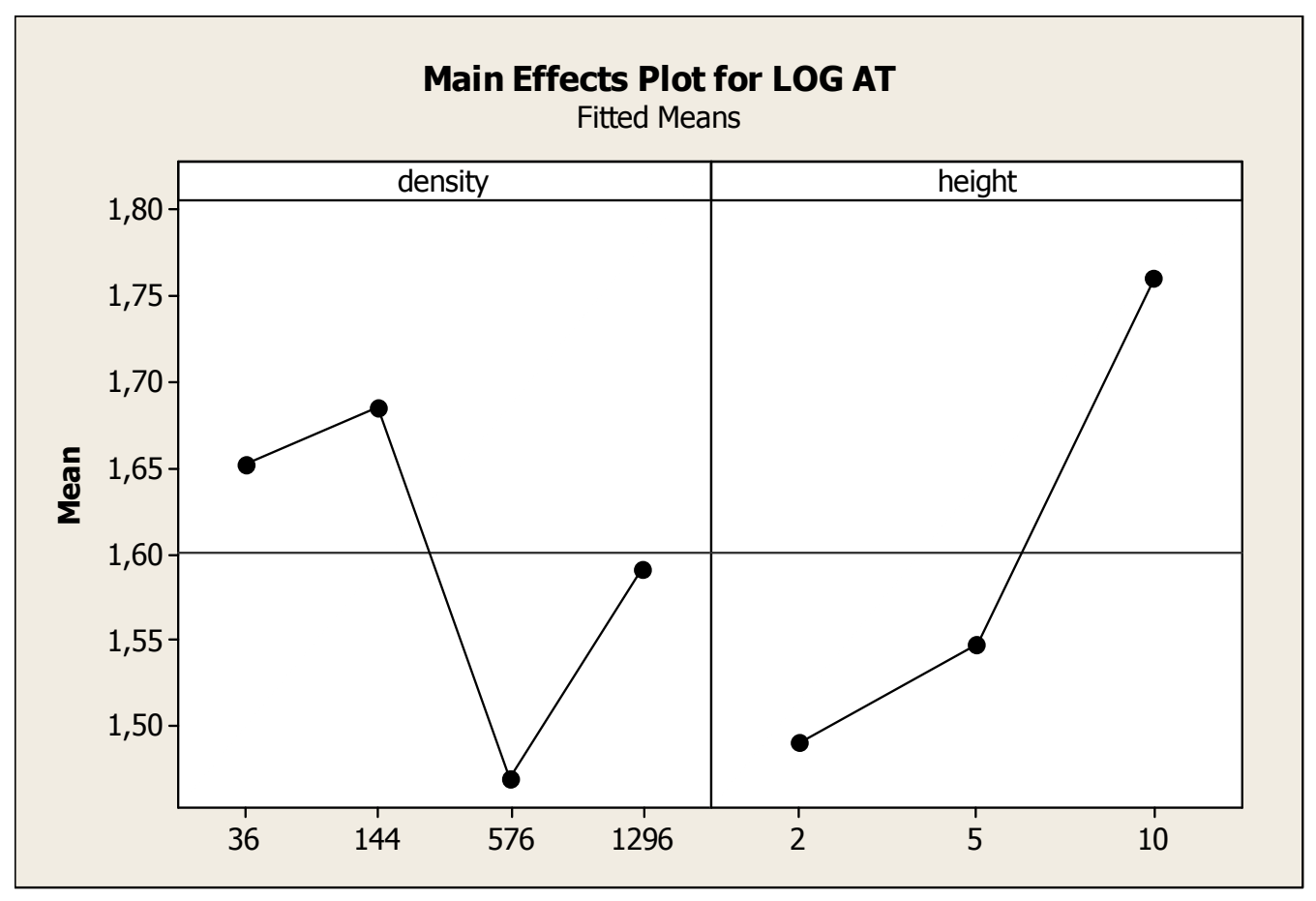

Figure 24 Hover: Main Effects Plot for LOG AT versus Object Height (3 levels), Object Density (4 levels)

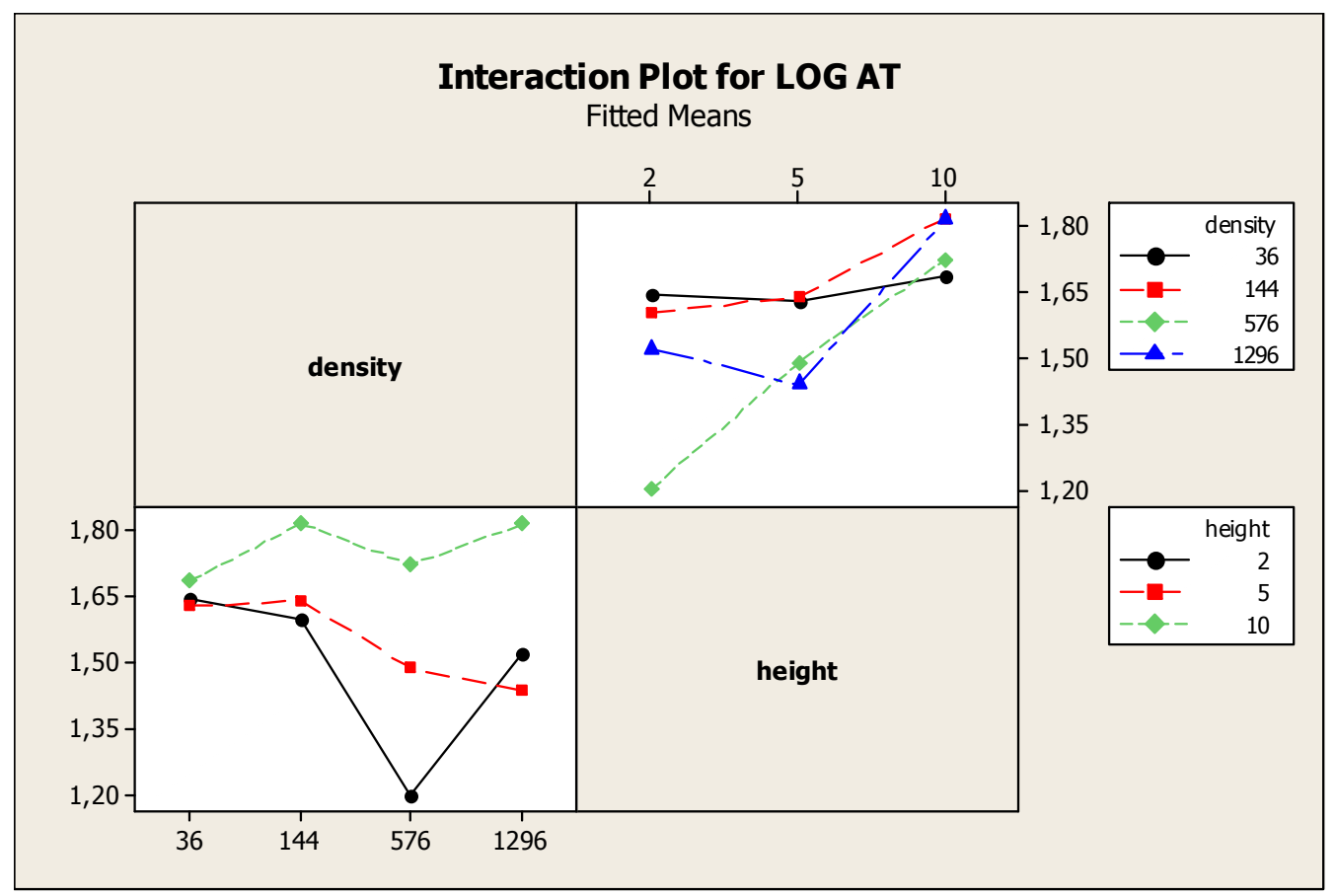

Figure 25 Hover: Interaction Plot for LOG AT versus Object Height (3 levels), Object Density (4 levels) 
In order to analyze the effect of mixture level of object height factor, another ANOVA comparison was conducted on the factors Subject, Object Density (4 levels) and Object Height (4 level) on LOGAT (Table 19 in the Appendix).

Object density ( $p=0.082, \alpha=0.05$ ) has no significant effect on altitude travelled performance, whereas object height $(p=0.002, \alpha=0.05)$ has significant effects on AT performance when mixture level was added to the object height levels. As shown in Figure 26 , mixture level was almost equal to $5 \mathrm{~m}$ object height level. Also, interaction of the object density and object height was not significant (object density* object height, $p=0.204$, $\alpha=0.05)$. This result is also confirmed by interaction plot (Figure 27).

Object height ( $f=0.41$ ) has medium to large effect size. Power of the object height is 0.99 (at $\alpha=0.05$ and $\mathrm{N}=160$ ). These power results show that it is unlikely that we falsely detected a significant difference.

No study investigating the vertical hovering performance is found in the literature.

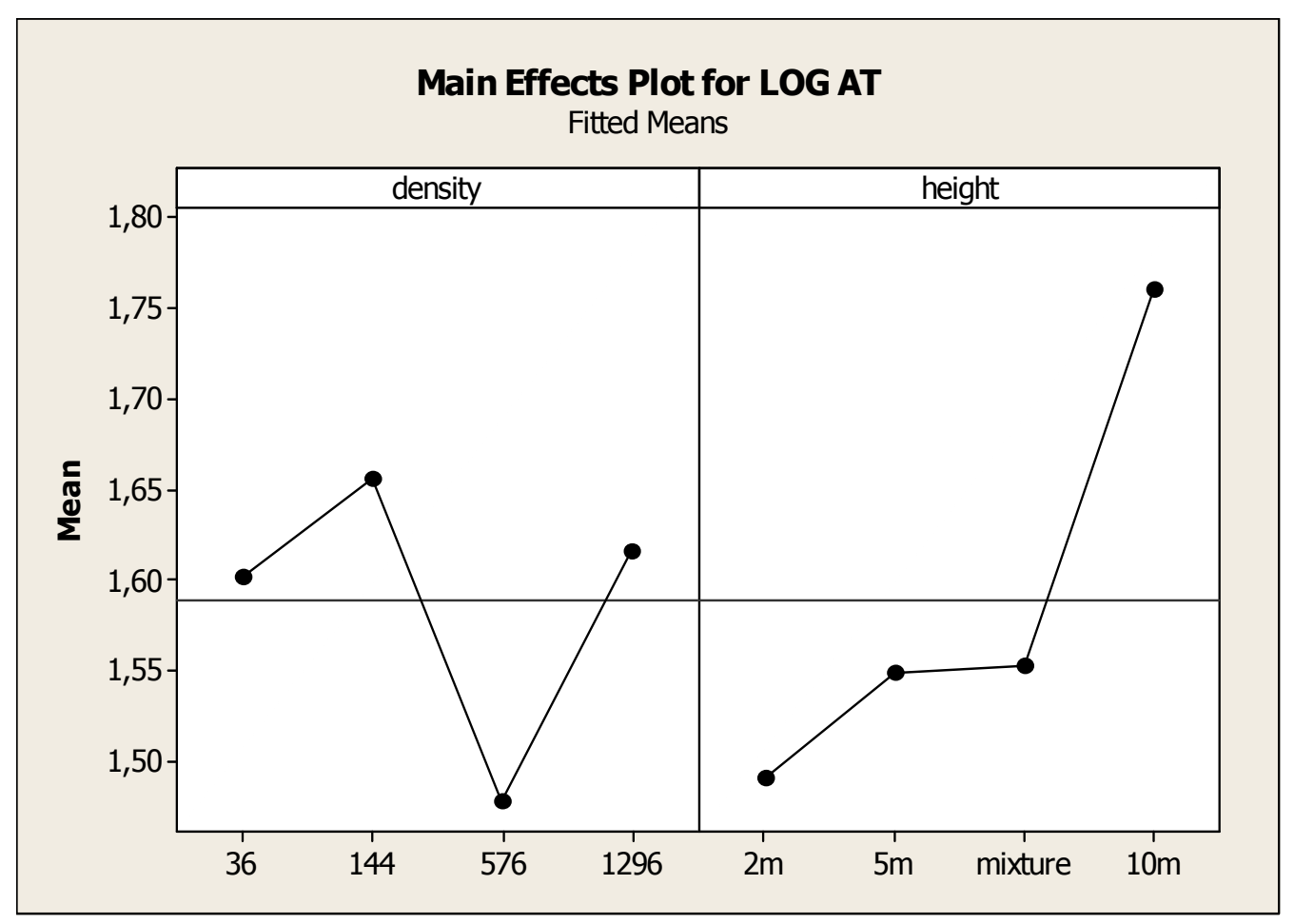

Figure 26 Hover: Main Effects Plot for LOG AT versus Object Height (4 levels), Object Density (4 levels) 


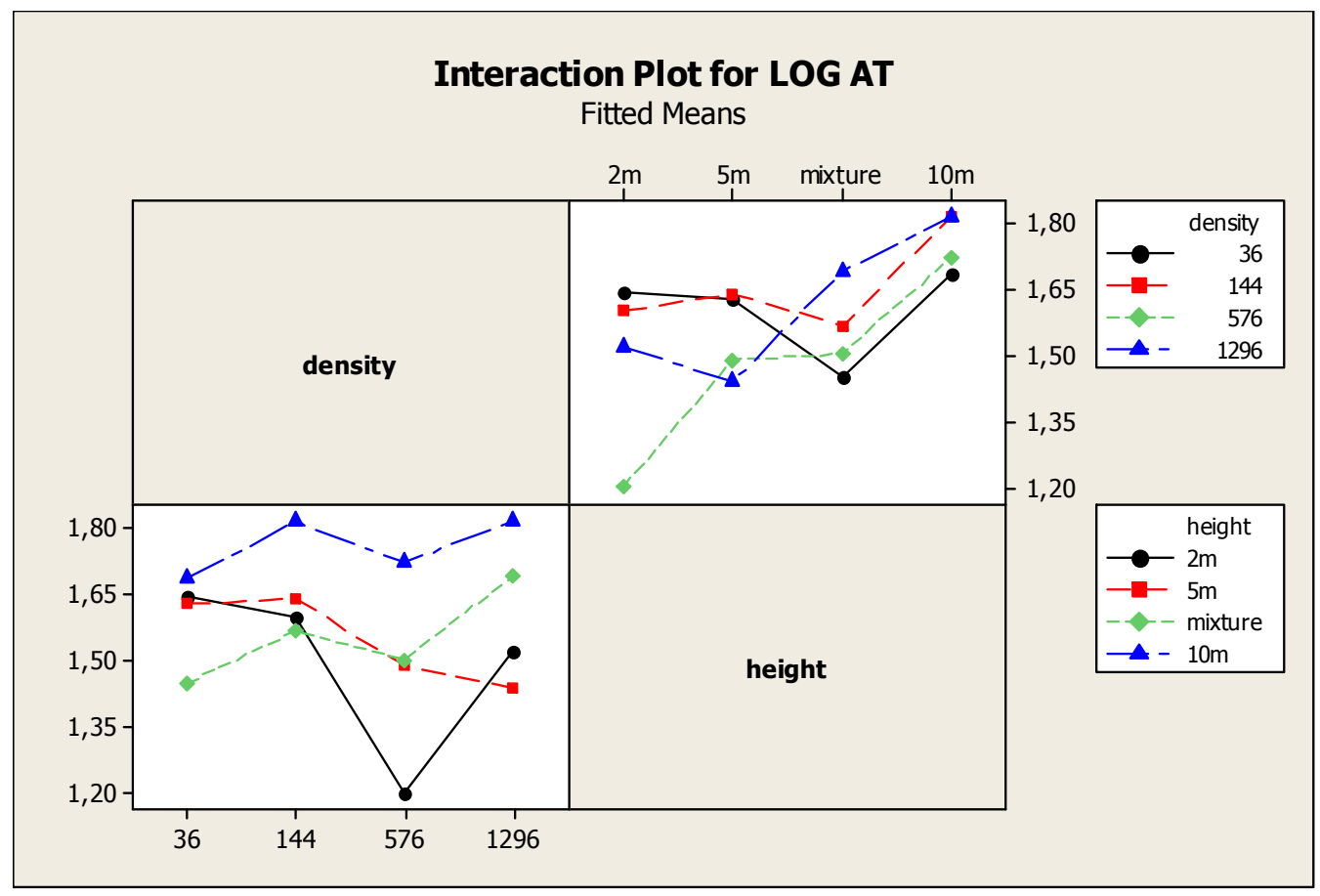

Figure 27 Hover: Interaction Plot for LOG AT versus Object Height (4 levels), Object Density (4 levels)

\subsection{Learning Effect for Low Altitude Flight}

To verify the randomization successfully eliminated the learning effect for low altitude flight, an ANOVA was conducted for Run Order (within block). The effect of run order on SEE, DEE and AT is presented in Table 20, Table 21 and Table 22 in the Appendix, respectively. These results are given separately for each performance.

\section{Speed Estimation Error:}

The order effect P-Value of 0.391 indicates there was no influence of order of the treatment (Table 20 in the Appendix). Also main effects plot (Figure 28) for SEE presents visual proof for absence of learning effect.

\section{Distance Estimation Error:}

There was an influence of order of the treatment $(p=0.000, \alpha=0.530)$ on DT performance (Table 21 in the Appendix). Main effects plot for DT (Figure 29) supports the absence of learning effect. 


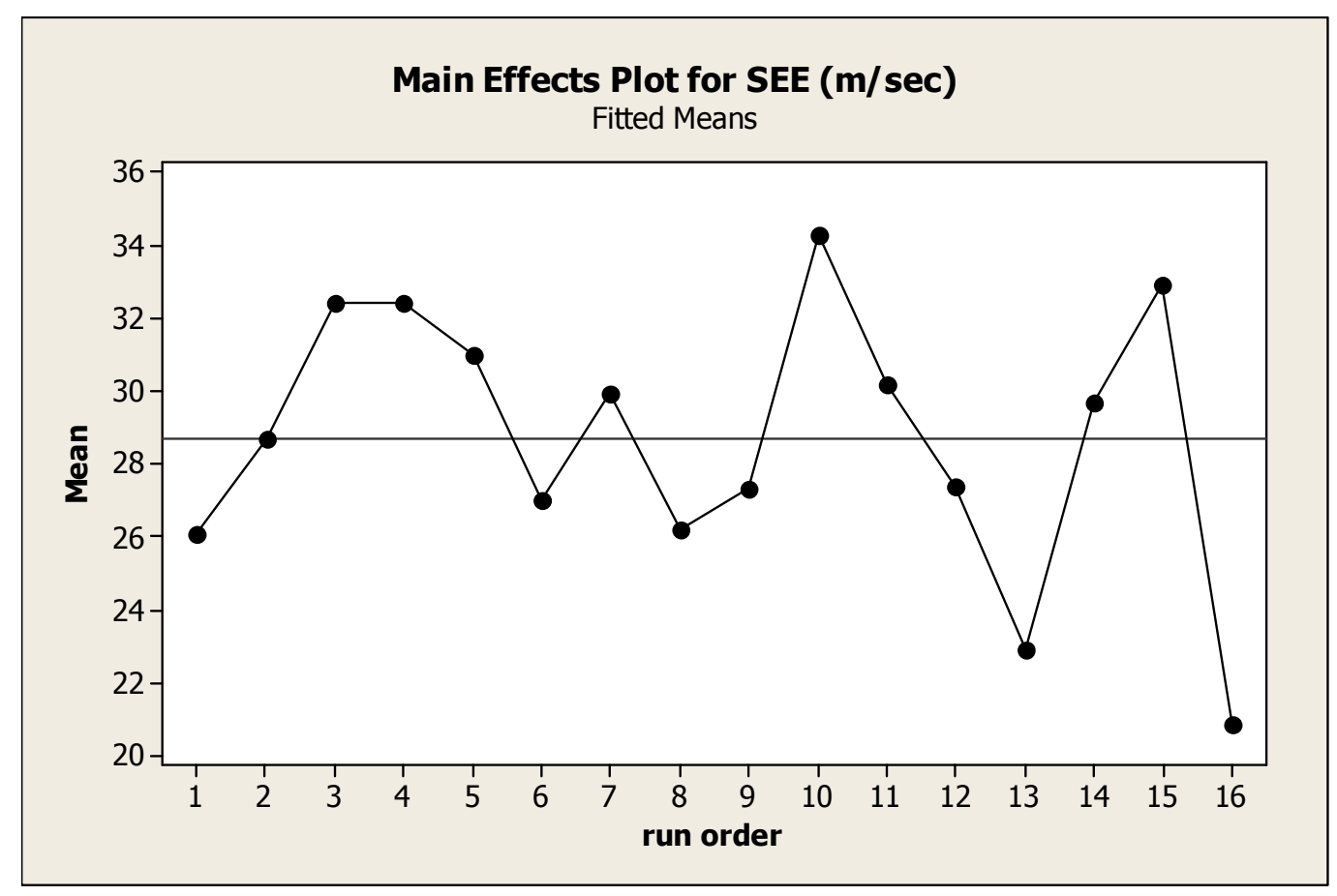

Figure 28 LAF: Main Effects of Run Order (With in Subjects) on SEE

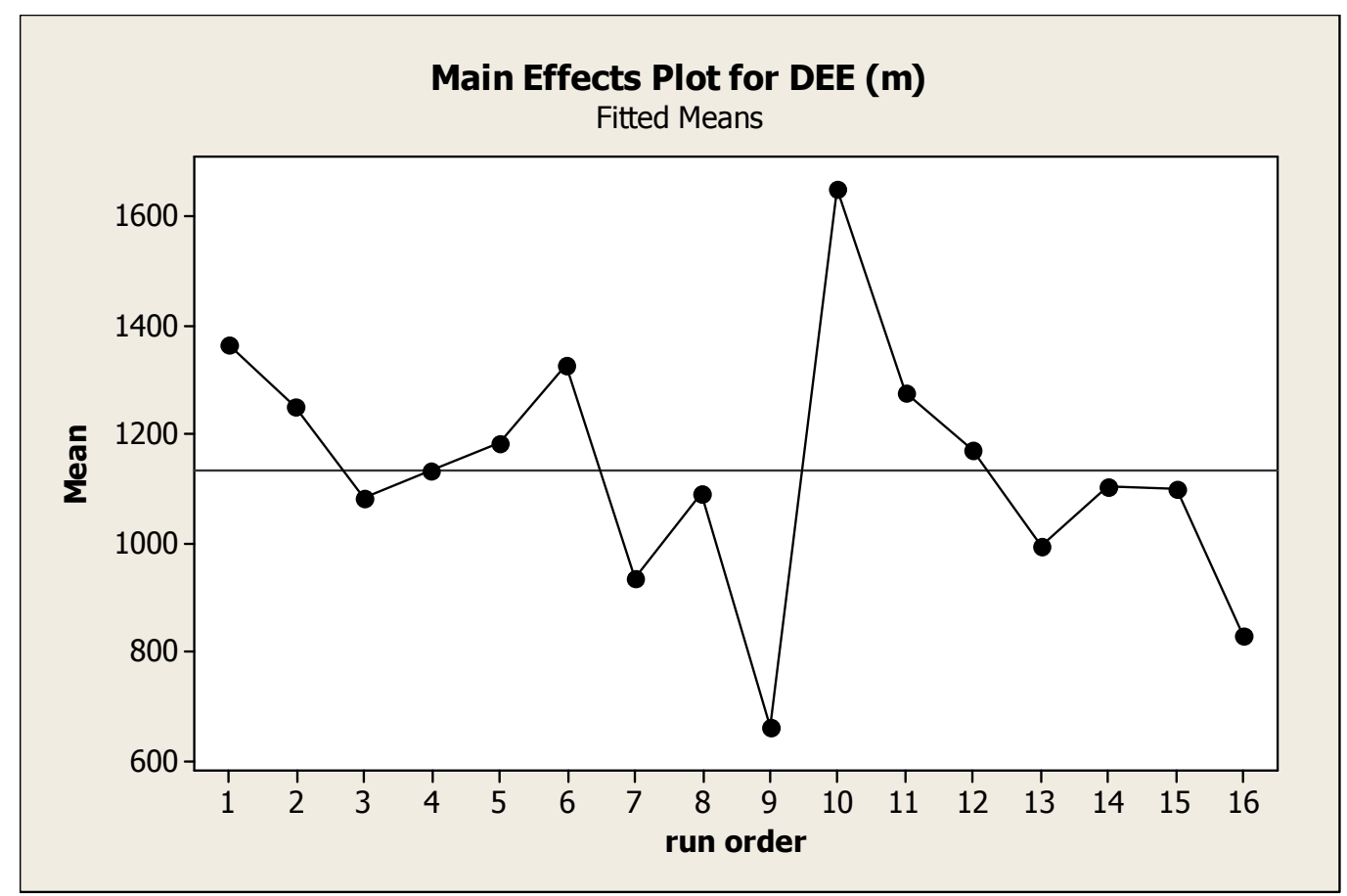

Figure 29 LAF: Main Effect of Run Order (Within Subjects) on DEE 


\section{Altitude Travelled:}

The order effect P-Value of 0.031 indicates there was influence of order of the treatment on AT performance (Table 22 in the Appendix). Also main effects plot (Figure 30) for AT presents learning effect on AT performance.

As shown in trend analysis plot (Figure 31), AT performances of the pilots improved during the experiment. We noticed that the AT values of the first run was higher than the others. These might affect the result. To see if this is the main reason for the learning effect we removed the first runs of all subjects and we repeated the ANOVA (Table 23 in the Appendix) for the remaining fifteen runs (Figure 32). However, the learning effect was still significant $(p=0.014)$ and trend analysis showed a less pronounced linear trend (Figure 32). It is conceivable that the pilots needed more time for familiarization on low altitude flight then they opted.

We attempted to compensate for the general trend (Figure 31 ) by subtracting the effect from all altitude travelled data of the subjects. However, the learning effect is highly dependent on the individual subject so that this compensation cannot be done using the general trend but the individual's learning curve has to be employed. As this significantly complicated the analysis we neglected the learning effects all together, and leave its analysis for further study.

\subsection{Horizontal Low Altitude Flight Performance}

In order to clarify the effect of object density and object height on horizontal low altitude flight performance, distance estimation error data was analyzed.

\subsubsection{Model Adequacy}

Model adequacy was tested as mentioned for horizontal hovering performance in Section 4.4. The variance of the residuals increases with the fitted values (Figure 56 and Figure 58). Taking the square root of the DEE for both 4 (object density)*3 (object height) levels and 4 (object density)*4 (object height) levels reduced the skewness and stabilized variance (Figure 57 and Figure 59). 


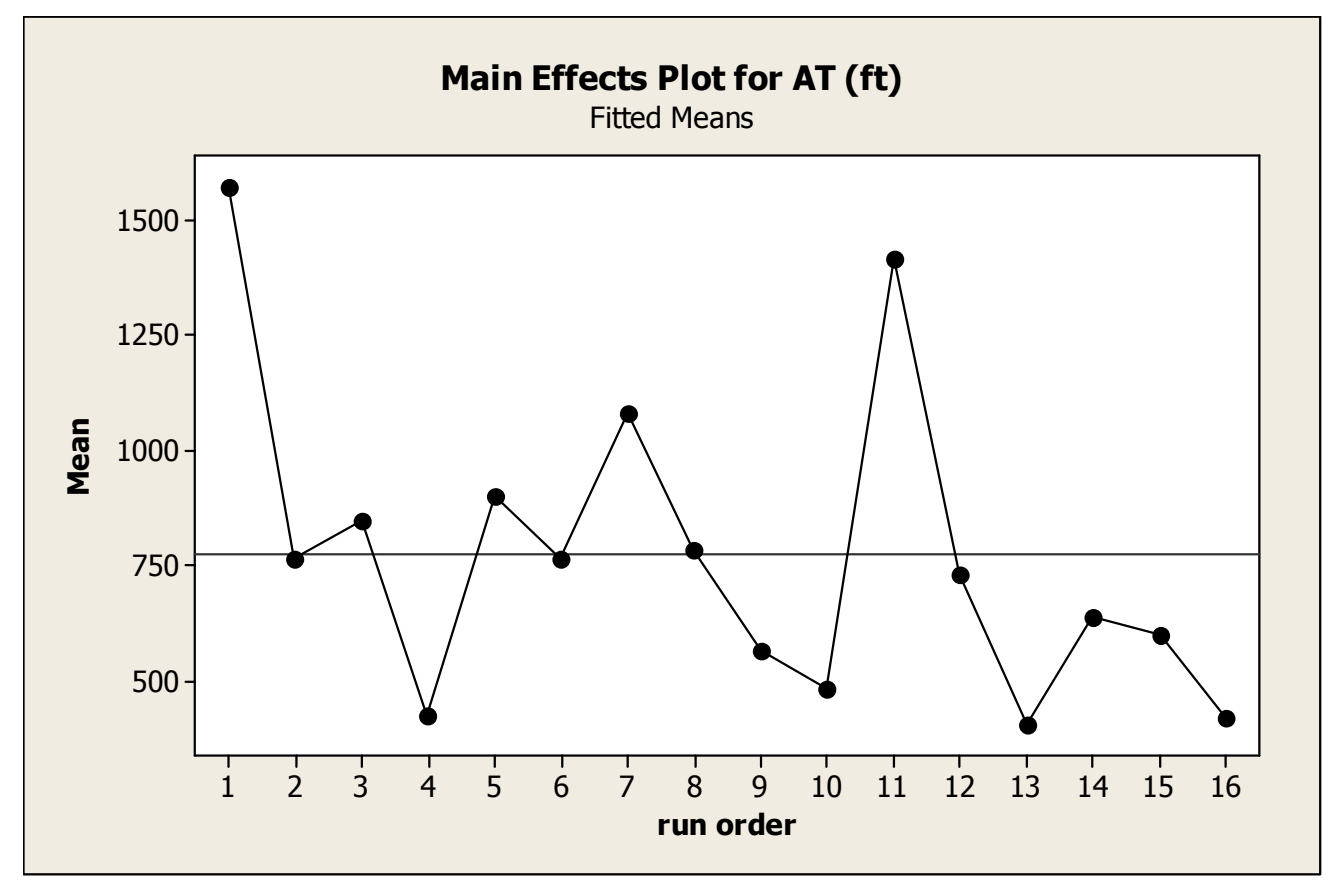

Figure 30 LAF: Main Effect of Run Order (Within Subjects) on AT

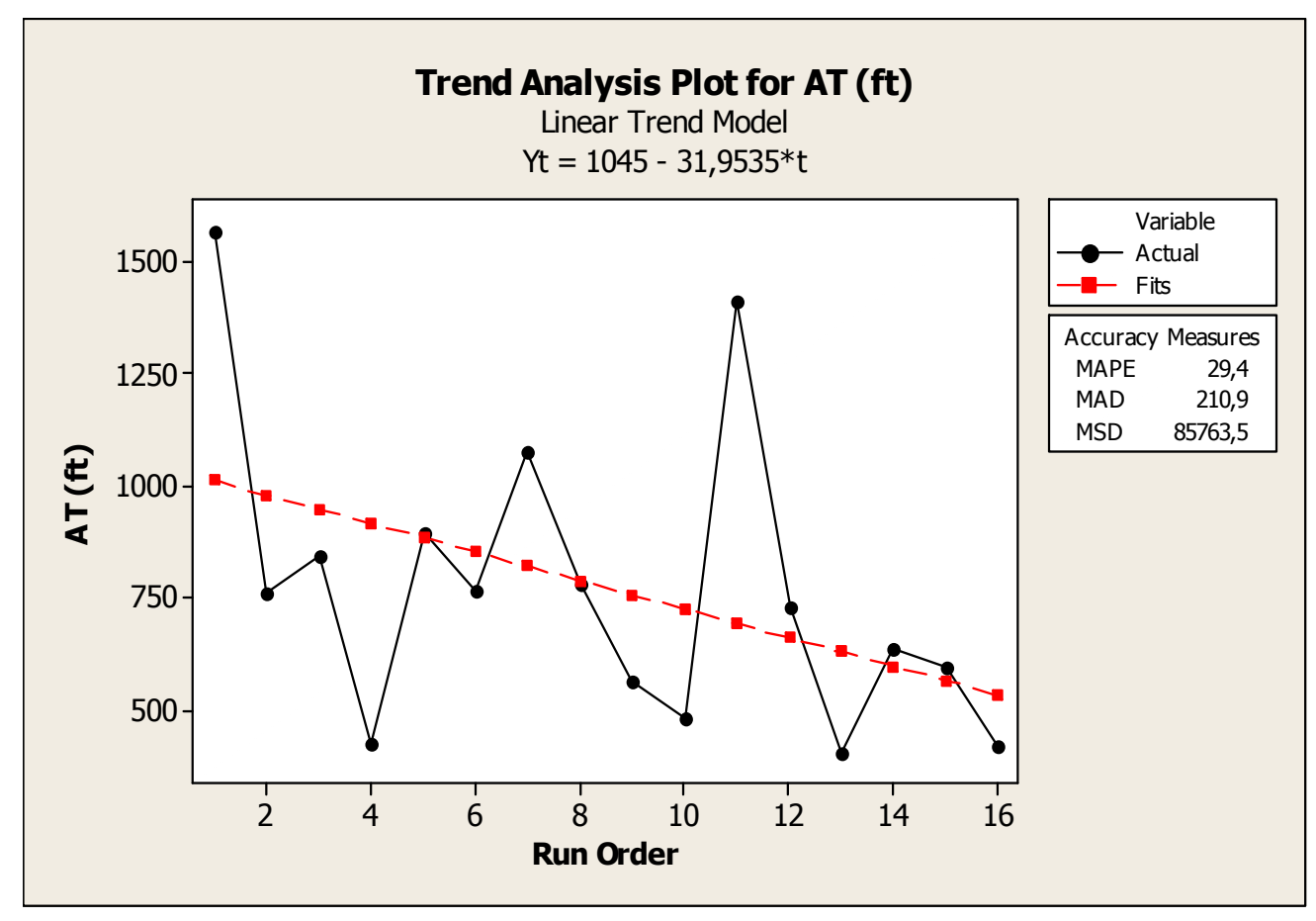

Figure 31 LAF: Trend Analysis Plot for AT 


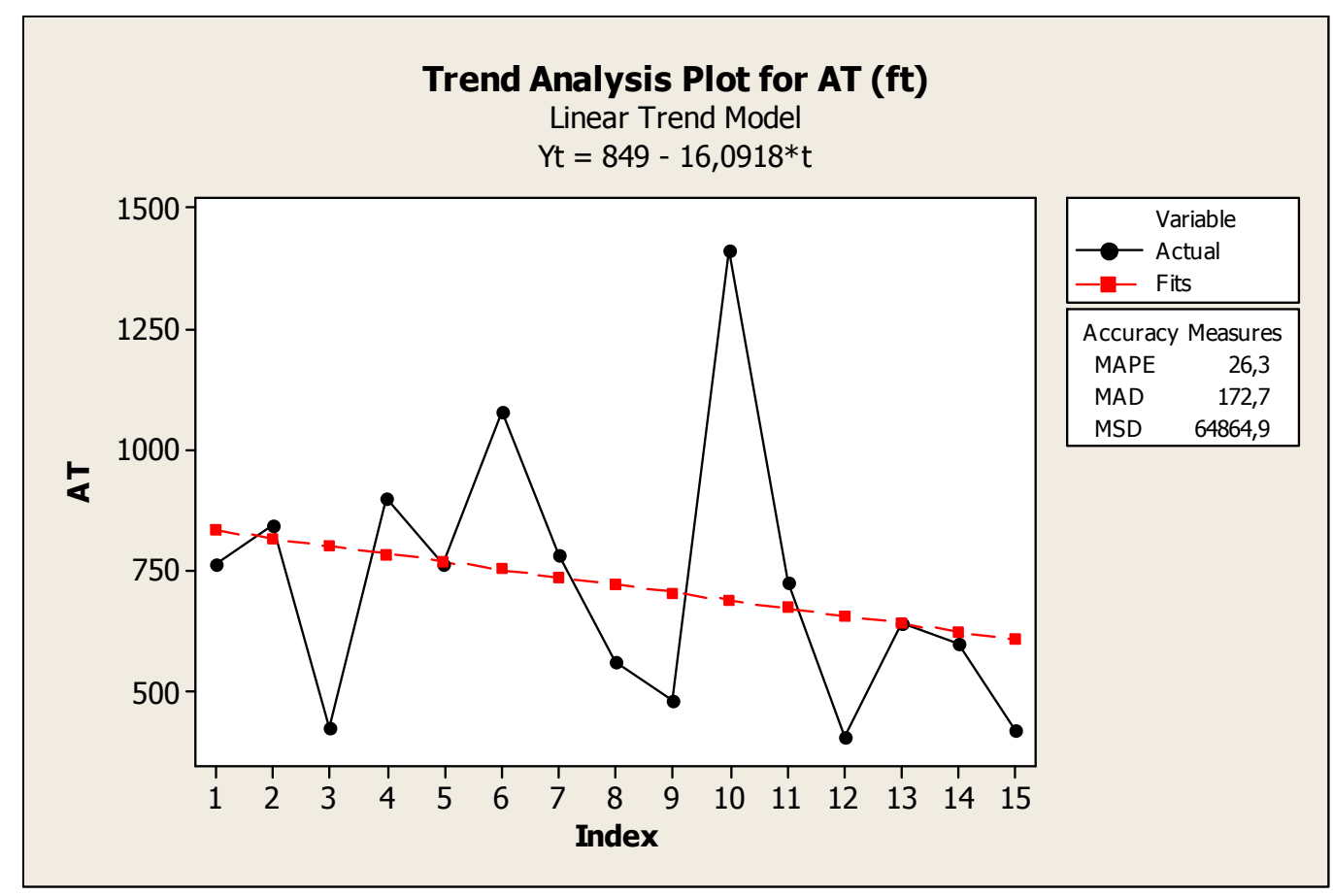

Figure 32 LAF: Trend Analysis Plot for AT without First Runs

\subsubsection{Results}

An ANOVA comparison was conducted on the factors Subject, Object Density (4 levels) and Object Height (3 level) on sqrt DEE (Table 24 in the Appendix). As depicted in ANOVA Table 24 , object density ( $p=0.450, \alpha=0.05)$ and object height ( $p=0.166, \alpha=0.05)$ have no significant effects on low altitude flight distance estimation performance.

As shown in Figure 33, when the object height increased, DEE of the participant also increased. Best object height for horizontal hover was $2 \mathrm{~m}$, second was $5 \mathrm{~m}$ and last was 10 $\mathrm{m}$ object. In terms object density, 144 objects per $\mathrm{km}^{2}$ was the best object density level for DEE (Figure 33). Also, there was a peak point at 144 objects per $\mathrm{km}^{2}$. Performance improved up to 144 objects per $\mathrm{km}^{2}$ density level. After that point increasing the object density decreased the performance.

Although object density and object height have no effect on the distance estimation, their interaction was significant (object density* object height, $p=0.018, \alpha=0.05$ ) (Figure 34). 
Object density and object height interaction ( $f=0.22$ ) has small to medium effect size. Power of the object density and height interaction is 0.37 (at $\alpha=0.05$ and $N=120$ ) indicating that the significant interaction effect we detected may become insignificant if a larger data set is used. More data-points are required to decrease the possibility of Type II error. The interaction of the object density and object height should be investigated on a larger data set.

We noticed that one of the subjects acted as an outlier for distance estimation and speed estimation. The ANOVA is repeated without that subject but significant factors remained the same. Only the results for the 10 subject case are presented here.

In order to analyze the effect of mixture level of object height factor, another ANOVA was conducted on the factors Subject, Object Density (4 levels) and Object Height (4 level) on sqrt DEE (Table 25 in the Appendix).

As depicted in ANOVA Table 25 in the Appendix, object density ( $p=0.922, \alpha=0.05)$ and object height $(p=0.339, \alpha=0.05)$ have no significant effect on DEE performance. The interaction of object density and object height was significant (object density* object height, $p=0.007, \alpha=0.05$ ) (Figure 36).

Object density and object height interaction ( $f=0.18$ ) has small to medium effect size. The power of object density and height interaction is 0.25 (at $\alpha=0.05$ and $N=160$ ), indicating that the significant interaction effect we detected may become insignificant if a larger data set is used. More data-points are required to decrease the possibility of Type II error. As shown in Figure 35, DEE performance of the participants at mixture object level whose average height is $5.66 \mathrm{~m}$ was close to that of $5 \mathrm{~m}$ level. 


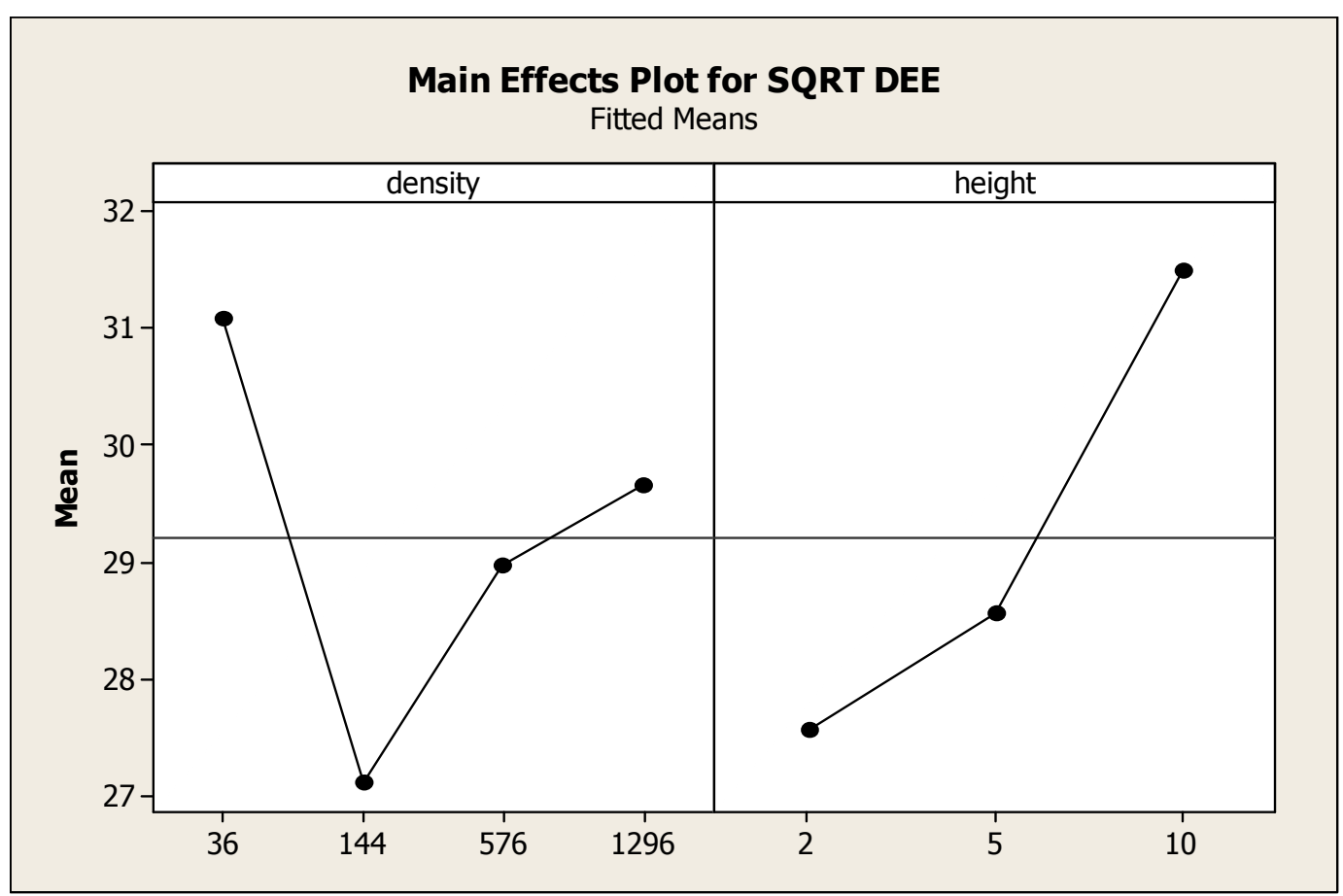

Figure 33 Hover: Main Effects Plot for SQRT DEE versus Object Height (3 levels), Object Density (4 levels)

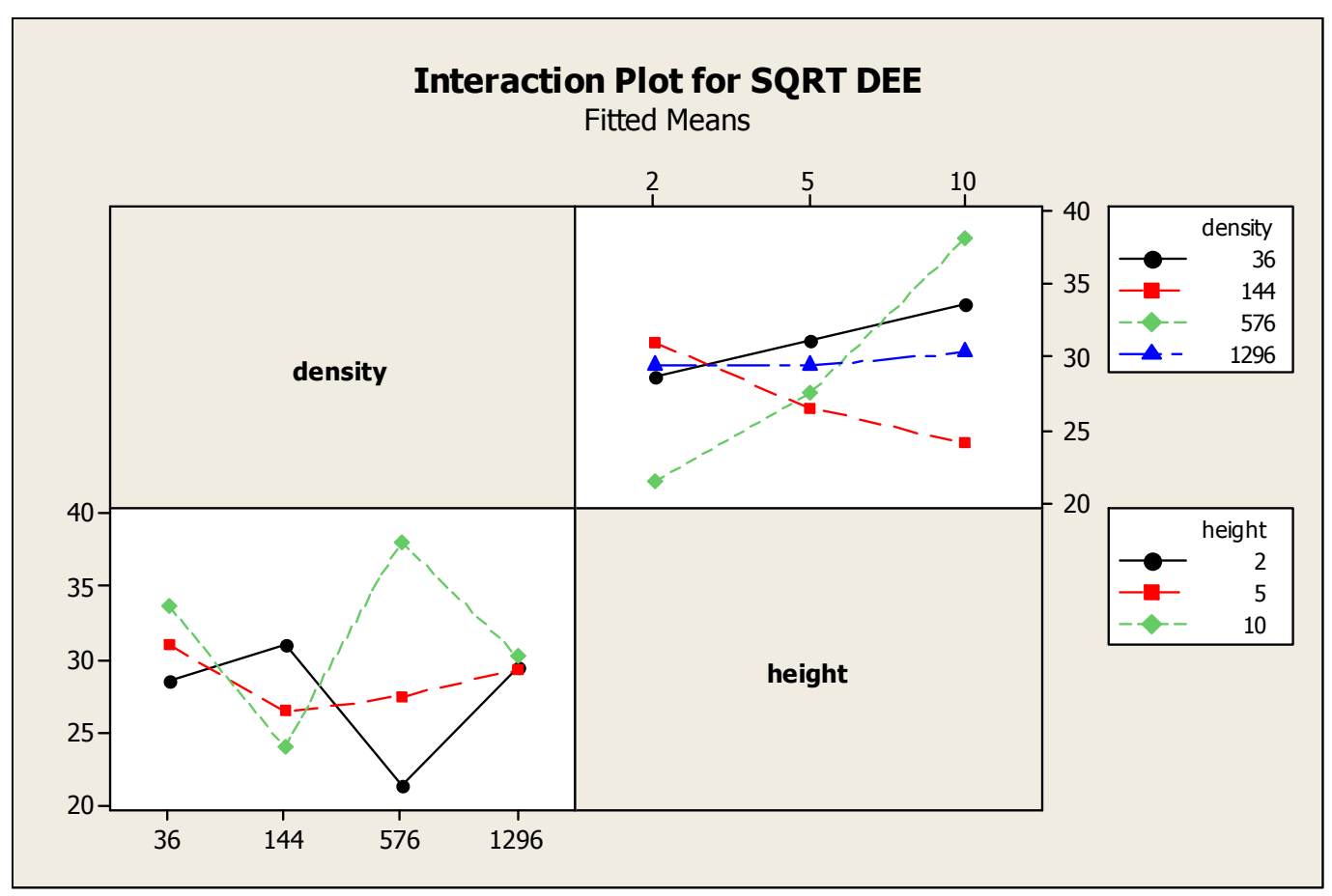

Figure 34 LAF: Interaction Effects Plot for SQRT DEE versus Object Height (3 levels), Object Density (4 levels) 


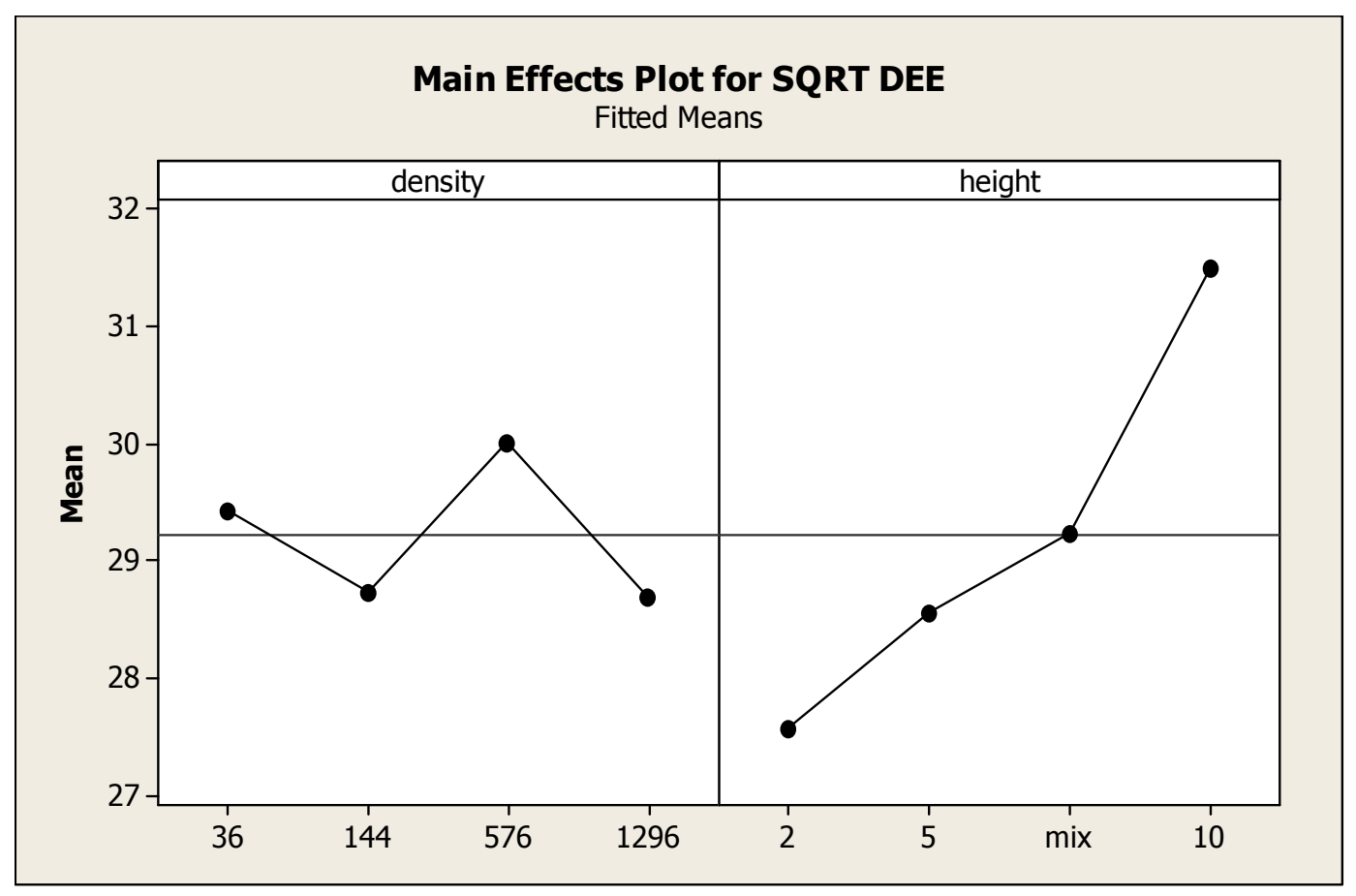

Figure 35 LAF: Main Effects Plot for SQRT DEE versus Object Height (4 levels), Object Density (4 levels)

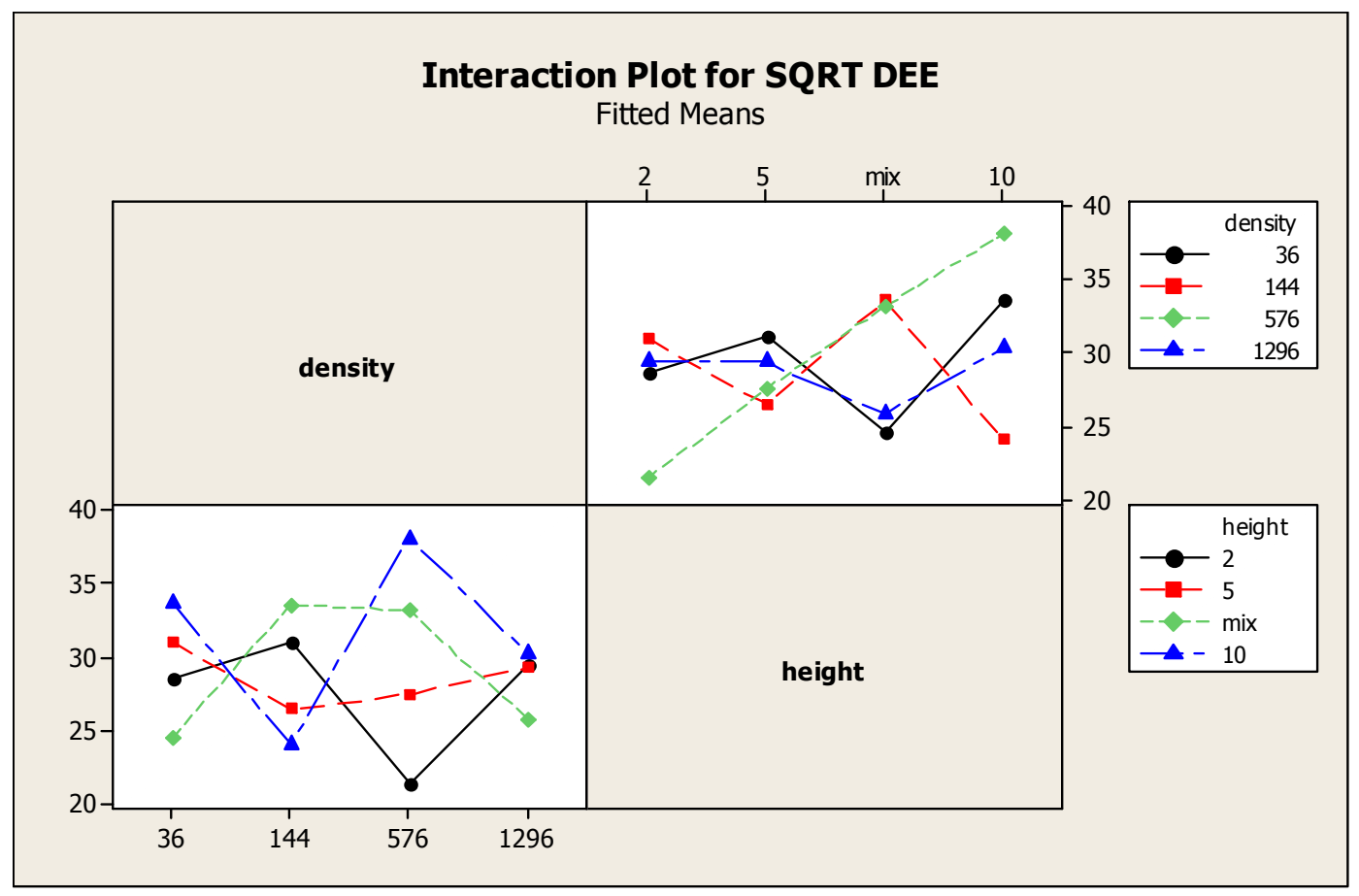

Figure 36 LAF: Interaction Effects Plot for SQRT DEE versus Object Height (4 levels), Object Density (4 levels) 


\subsection{Vertical Low Altitude Flight Performance}

In order to clarify the effect of object density and object height on horizontal low altitude flight performance, altitude travelled data was analyzed.

\subsubsection{Model Adequacy}

Model adequacy was tested as mentioned for horizontal hovering performance in Section 4.4 (Figure 60 and Figure 62 in the Appendix). The logarithm of the AT for both 4(object density)*3 (object height) levels and 4 (object density)*4 (object height) levels was taken in order to solve the increasing variance problem (Figure 61 and Figure 63 in the Appendix).

\subsubsection{Results}

An ANOVA was conducted on the factors Subject, Object Density and Object Height on log AT (Table 26 in the Appendix).Object density ( $p=0.268, \alpha=0.05$ ) has no significant effect on AT, whereas object height ( $p=0.000, \alpha=0.05$ ) has significant effect on altitude travelled performance of low altitude flight. Object height $(f=0.64)$ has a large effect size. Power of the object height is 0.99 (at $\alpha=0.05$ and $N=120$ ). These power results show that it is unlikely that we falsely detected a significant difference.

It was shown in main effects plot in Figure 36 that when the object height increased, AT performance of the participant decreased. Best object height was $2 \mathrm{~m}$, second was $5 \mathrm{~m}$ and last was $10 \mathrm{~m}$ object. Best object density level was 576 objects per $\mathrm{km}^{2}$ (Figure 37) before and after which the performance degraded. Also, interaction of the object density and object height ( $p=0.754, \alpha=0.05$ ) was not significant (Figure 38 ).

In order to analyze the effect of mixture level of object height factor, another ANOVA was conducted on the factors Subject, Object Density (4 levels) and Object Height (4 level) on LOGAT (Table 27 in the Appendix).

Object density $(p=0.518, \alpha=0.05)$ has no significant effect on altitude travelled performance, whereas object height $(p=0.000, \alpha=0.05)$ has significant effects on DT 
performance when the mixture level was added to object height level. Object height ( $f=0.51$ ) has a large effect size. Power of the object height is 0.99 (at $\alpha=0.05$ and $N=160$ ). These power results show that it is unlikely that we falsely detected a significant difference.

As shown in Figure 39, mixture level was between the $5 \mathrm{~m}$ and $10 \mathrm{~m}$ levels in terms of AT performance. Even though mean height is $5.66 \mathrm{~m}$ for the mixture, its mean effect is closer to that of $10 \mathrm{~m}$. This could be due to the prominence of higher objects during low altitude flight. Also, their interaction was not significant (object density* object height, $p=0.498$, $\alpha=0.05$ ). This result is also confirmed by interaction plot (Figure 40 ).

Pongracic (2003) claimed that altitude perception would improve with vertical object height increase. Result of the current study contradicts her claim. Participants performed better with small objects than tall objects.

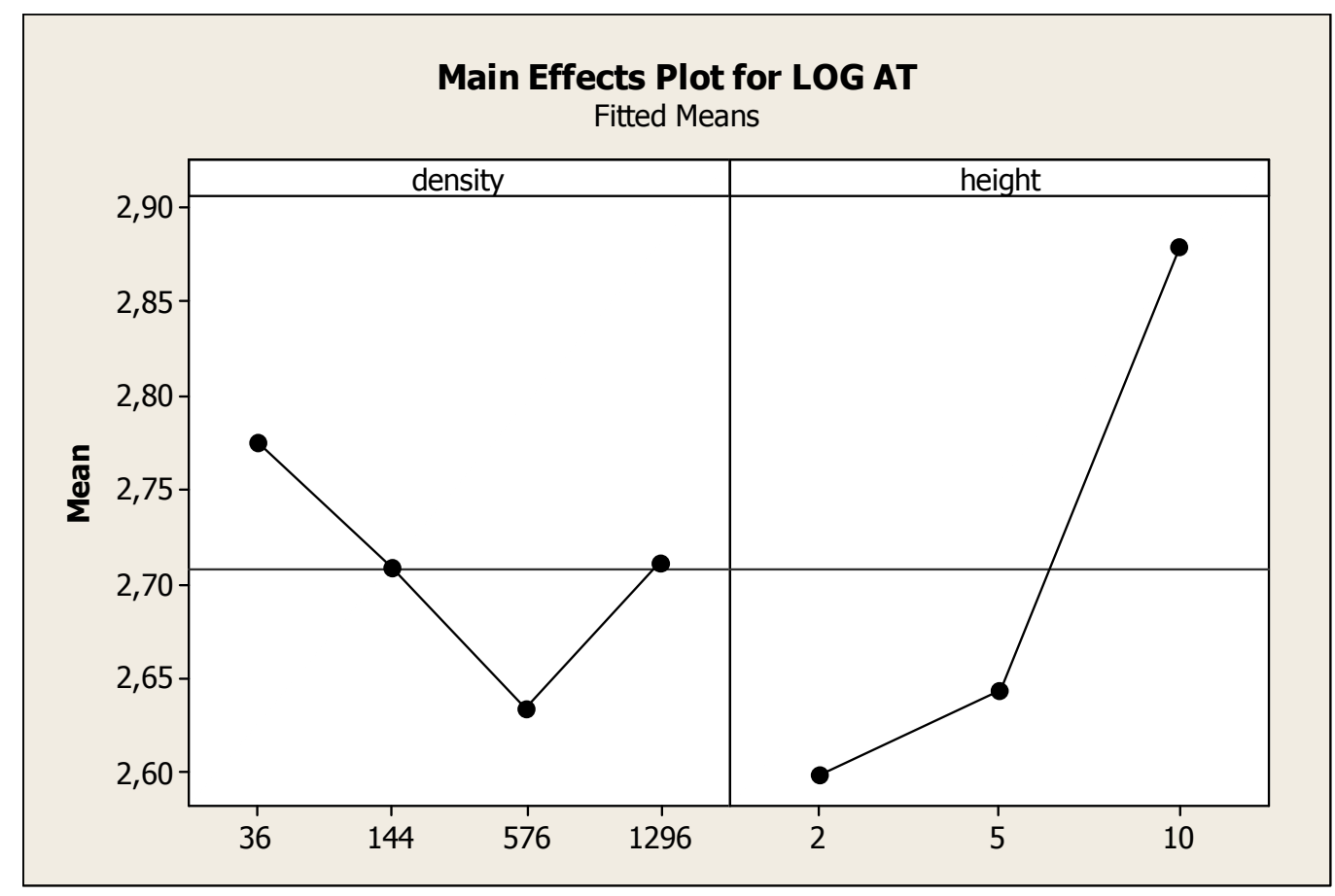

Figure 37 LAF: Main Effects Plot for LOG AT versus Object Height (3 levels), Object Density (4 levels) 


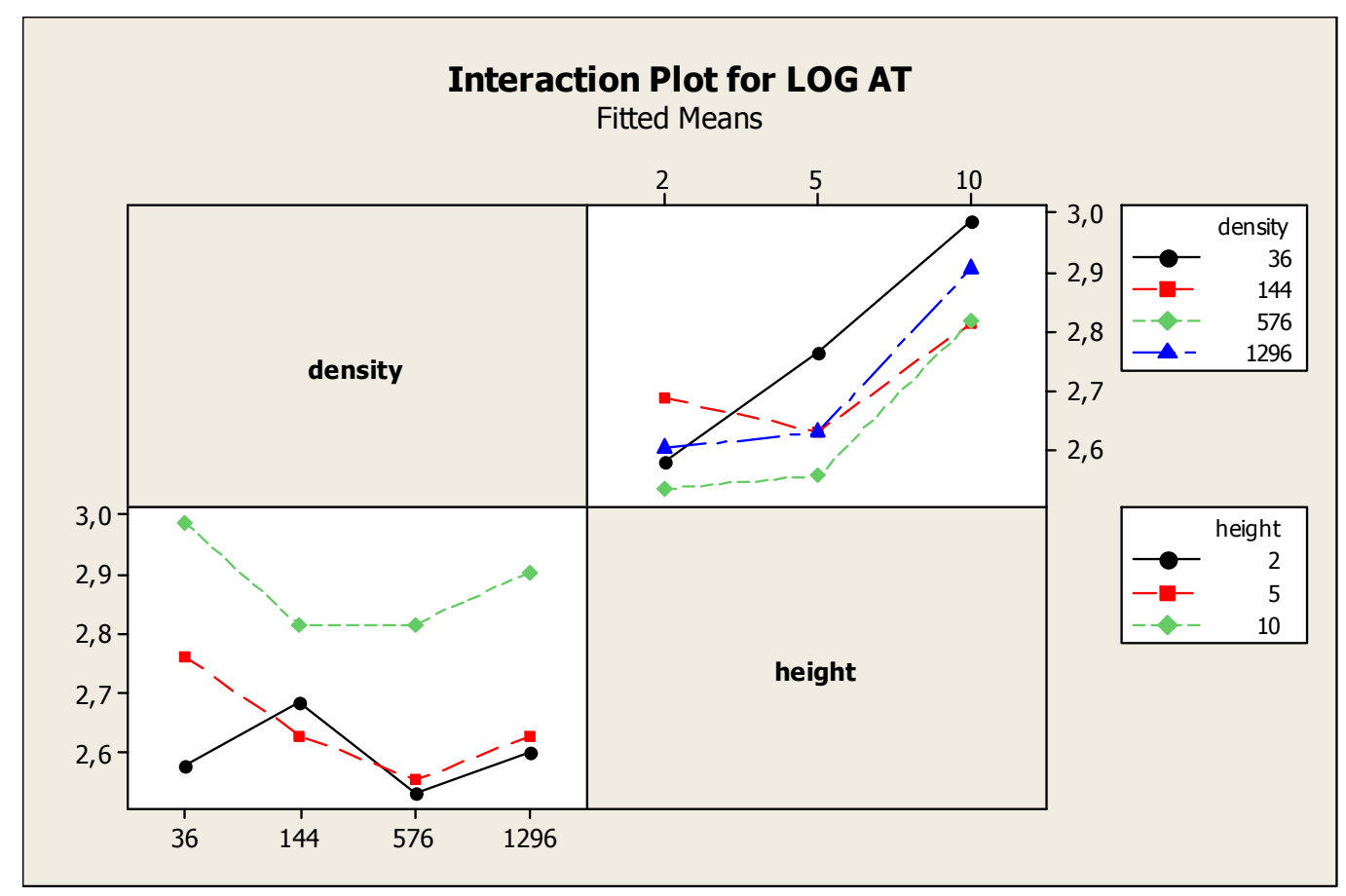

Figure 38 LAF: Interaction Effects Plot for LOG AT versus Object Height (3levels), Object Density (4 levels)

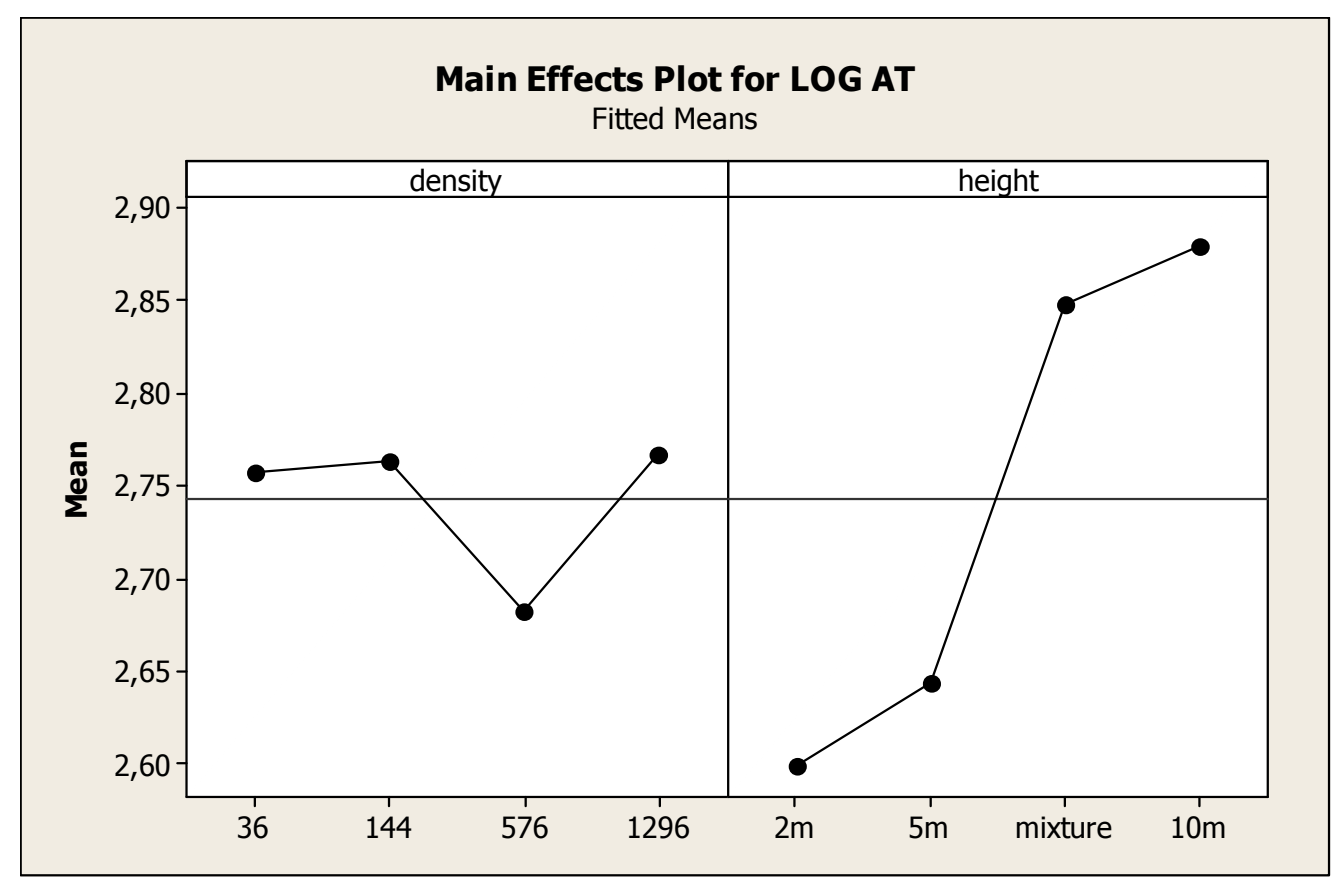

Figure 39 LAF: Main Effects Plot for LOG AT versus Object Height (4 levels), Object Density (4 levels) 


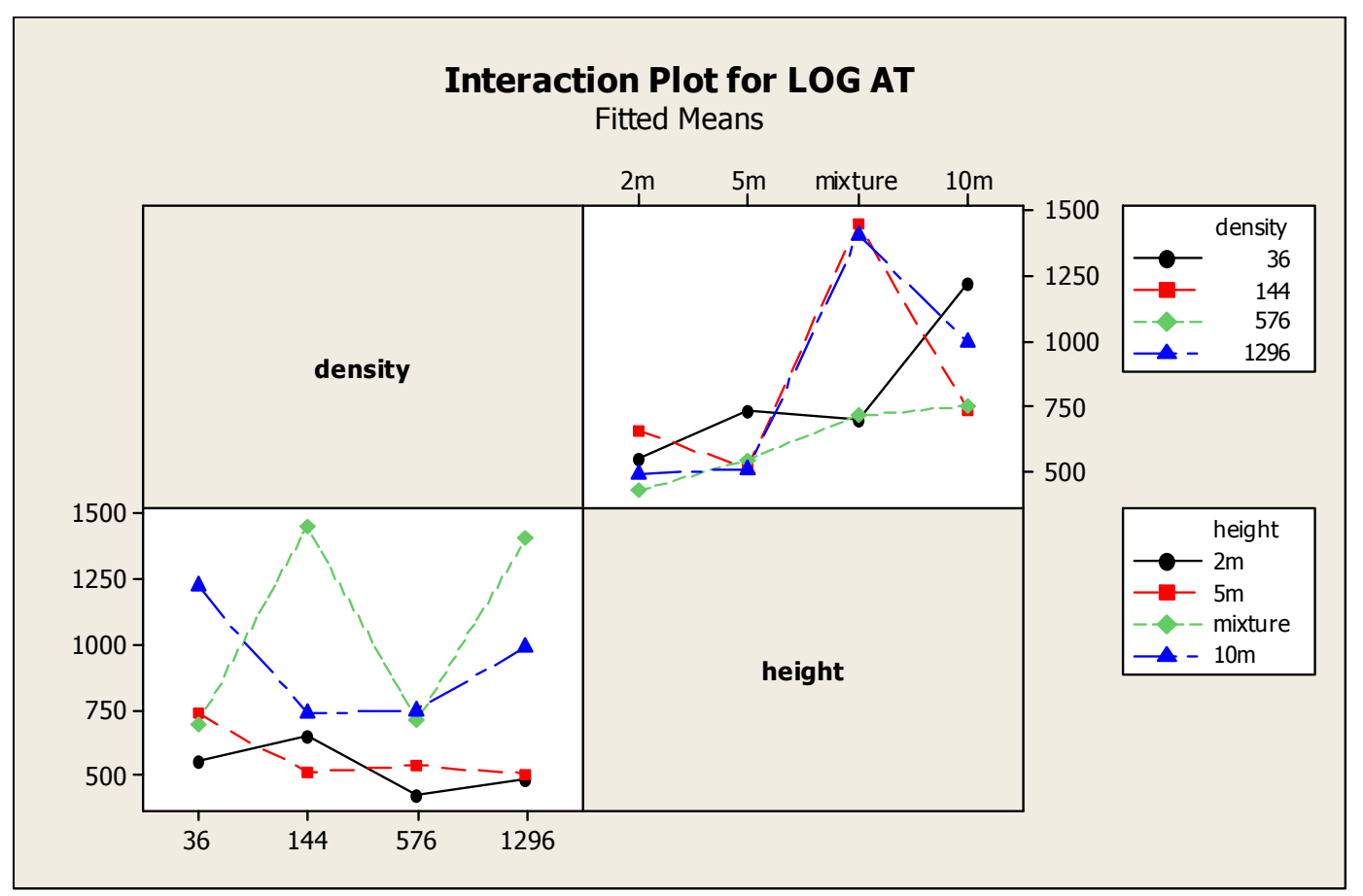

Figure 40 LAF: Interaction Effects Plot for LOG AT versus Object Height (4 levels), Object Density (4 levels)

\subsection{Speed Estimation Performance}

In order to clarify the effect of object density and object height on speed estimation performance, SEE data was analyzed.

\subsubsection{Model Adequacy}

Model adequacy was tested similar to the horizontal hovering performance in Section 4.4. At both 4 (object density)* 3 (object height) levels and 4 (object density)*4 (object height) levels assumptions were satisfied. Therefore, there was no need for transforming the SEE data (Figure 64 and Figure 65 in the Appendix).

\subsubsection{Results}

An ANOVA was conducted on the factors Subject, Object Density (4 levels) and Object Height (3 level) on SEE (Table28 in the Appendix). Neither object density ( $p=0.189, \alpha=0.05$ ), 
object height ( $p=0.504, \alpha=0.05$ ) nor their interaction, object density and object height ( $p=0.419, \alpha=0.05$ ) have no significant effects on low altitude flight speed estimation error performance (Figure 41 and Figure 42).

In order to analyze the effect of mixture level of object height factor, another ANOVA was conducted on the factors Subject, Object Density (4 levels) and Object height (4 level) on SEE (Table 29 in the Appendix).

Object density ( $p=0.133, \alpha=0.05)$ and object height ( $p=0.585, \alpha=0.05$ ) have no significant effects on SEE performance. As shown in Figure 43, SEE performance of participant was similar to that of $10 \mathrm{~m}$ for mixture object height. Also, their interaction was not significant (object density* object height, $p=0.352, \alpha=0.05$ ). This result is also confirmed by interaction plot (Figure 44).

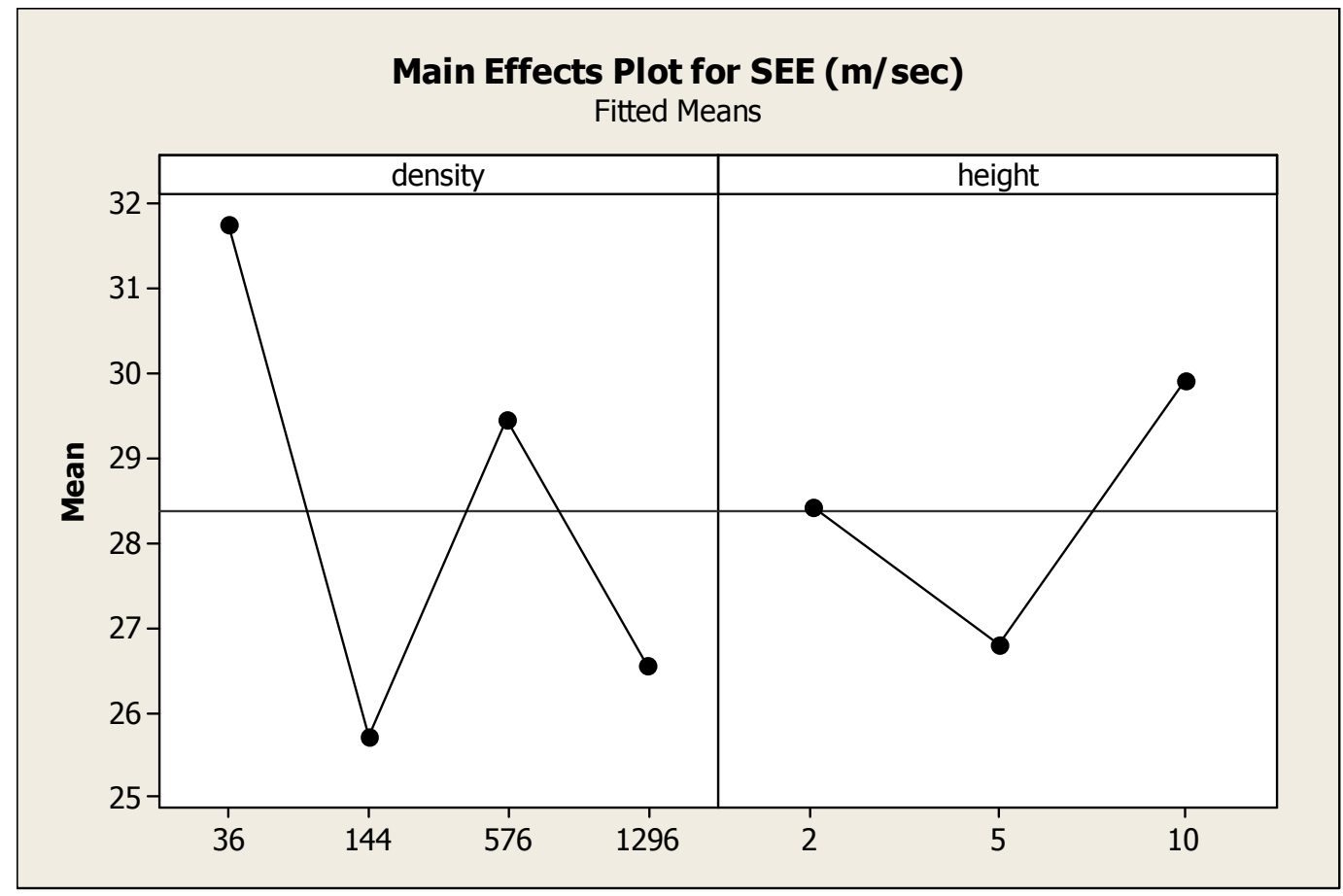

Figure 41 LAF: Main Effects Plot for SEE versus Object Height (3 levels), Object Density (4 levels) 


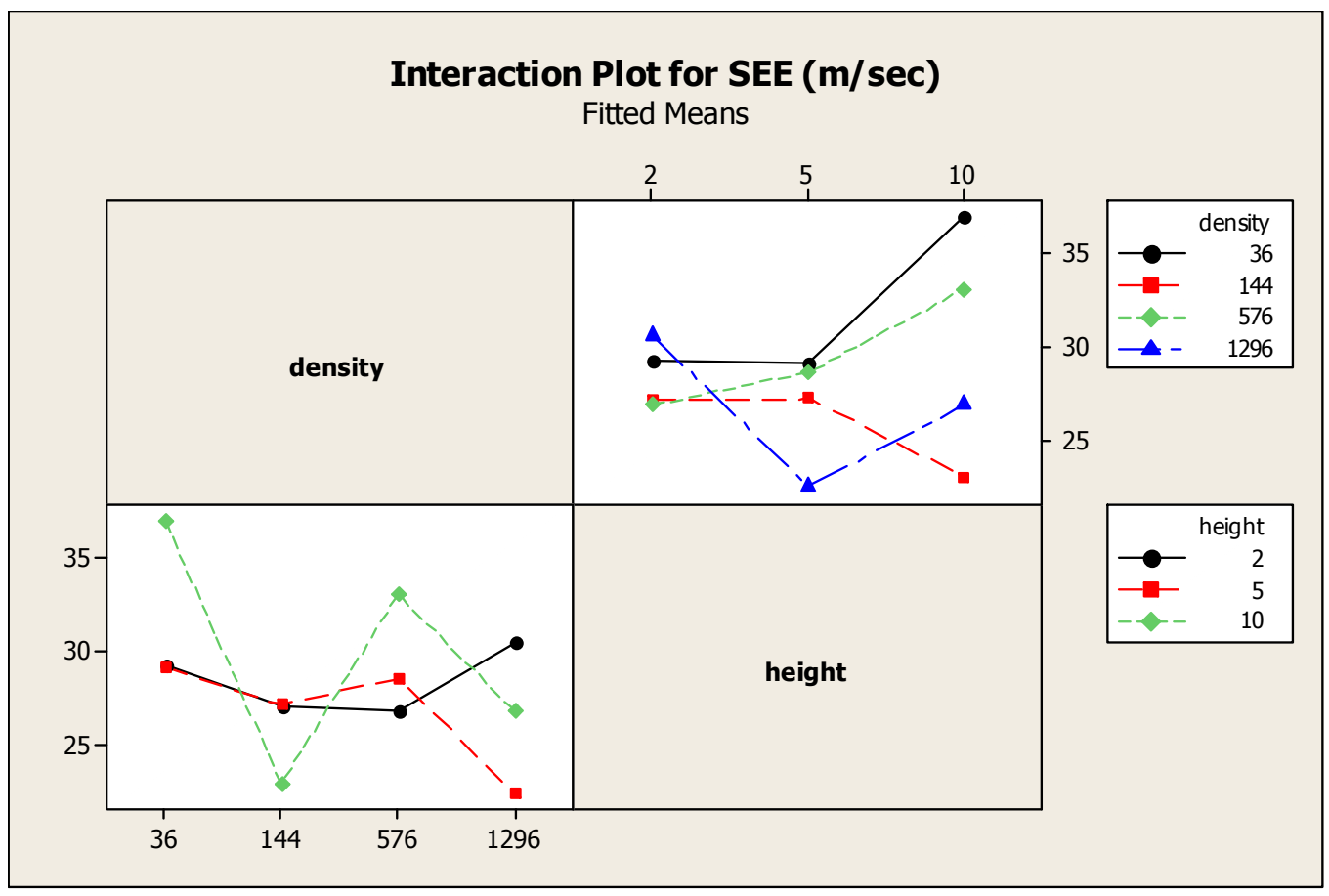

Figure 42 LAF: Interaction Effects Plot for SEE versus Object Height (3 levels), Object Density (4 levels)

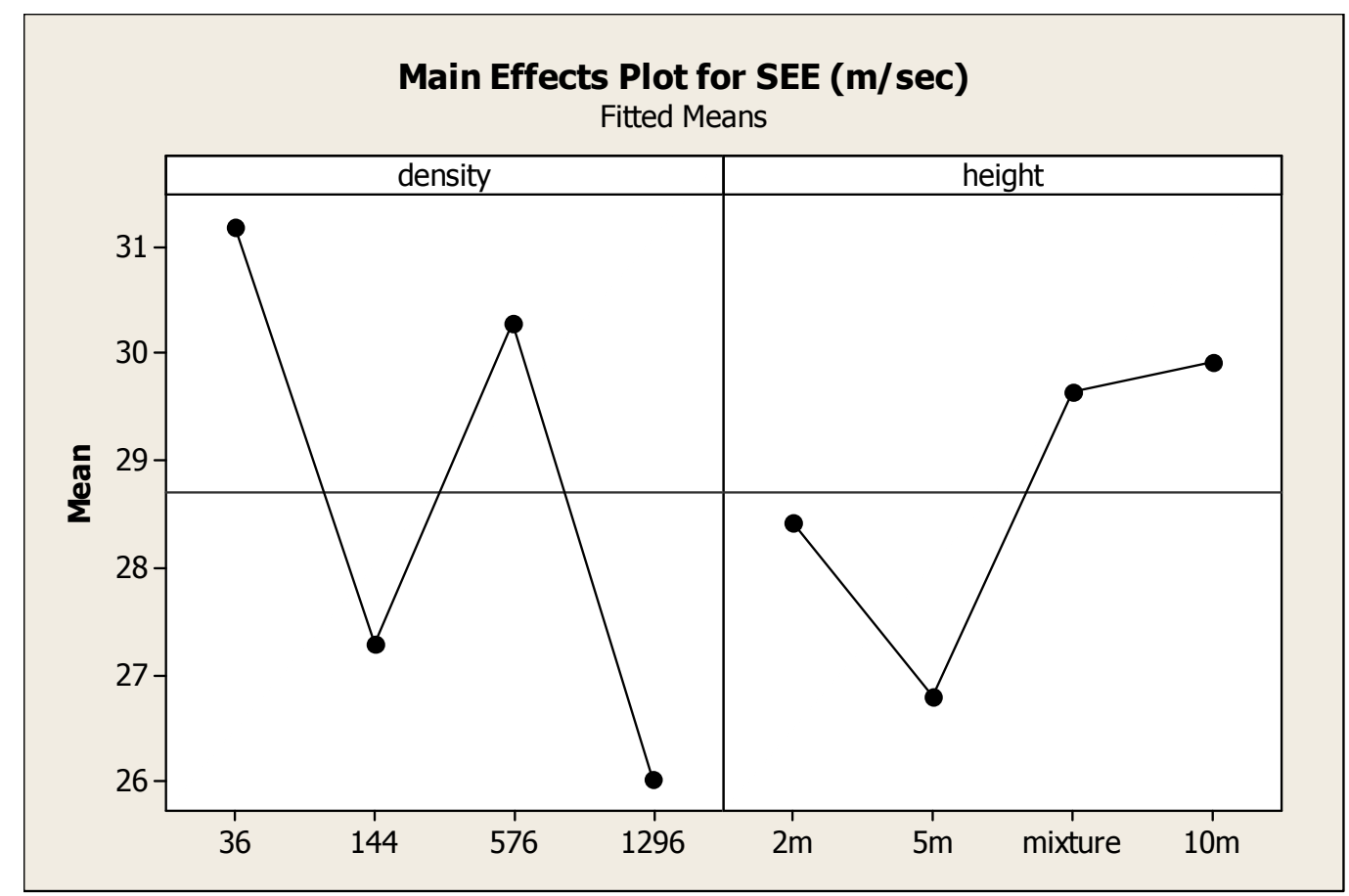

Figure 43 LAF: Main Effects Plot for SEE versus Object Height (4 levels), Object Density (4 levels) 


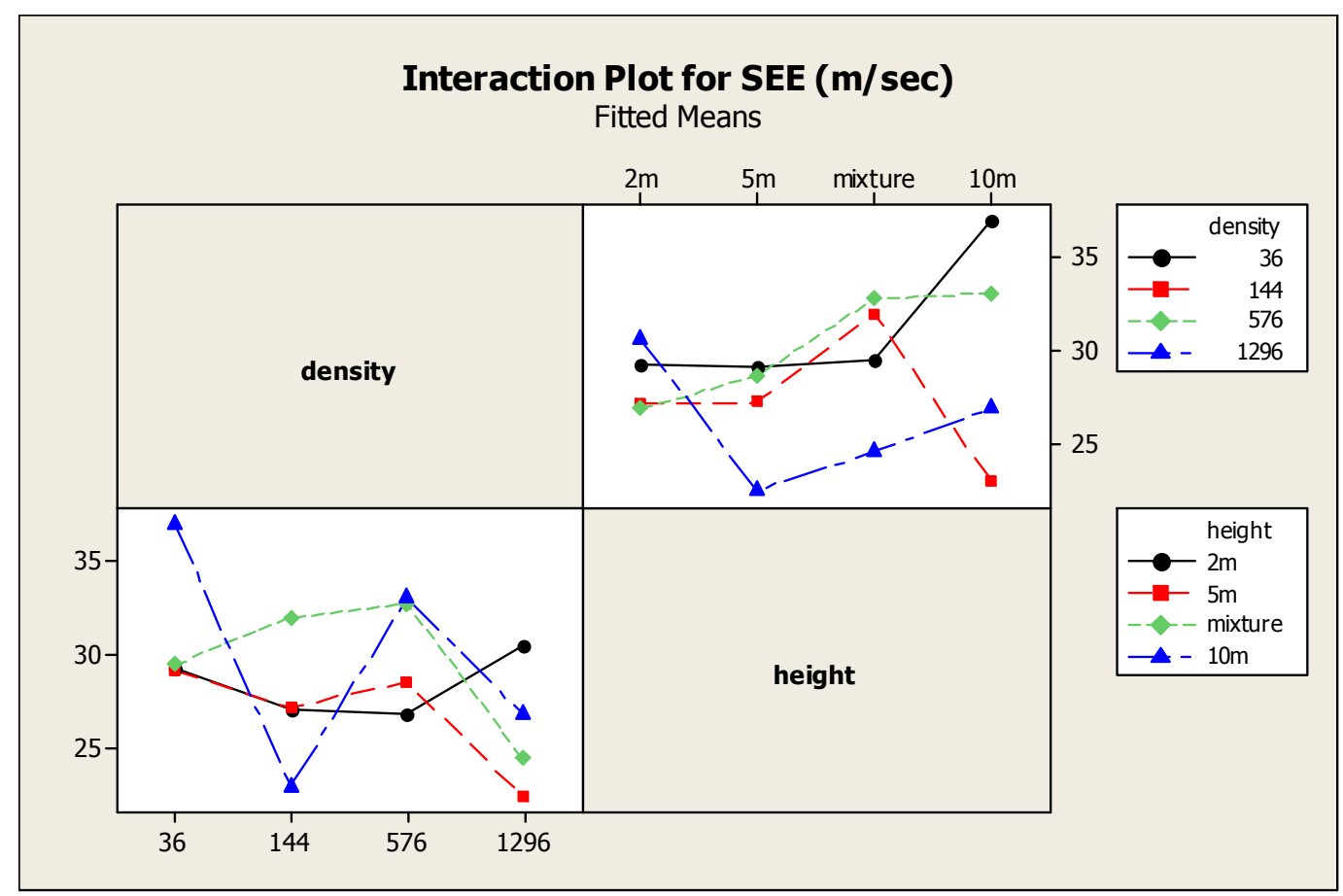

Figure 44 LAF: Interaction Effects Plot for SEE versus Object Height (4 levels), Object Density (4 levels)

\subsection{Discussion}

Specific altitude requirements of hover could also explain the superiority of smaller objects. As it is performed at 3-15 feet $(\sim 1-5 \mathrm{~m})$, the objects that are smaller than the required height such as $2 \mathrm{~m}$ are seen from the top. Also, $5 \mathrm{~m}$ objects were almost equal to the flight height (Figure 45). Moreover, the pilot would not need to avoid the objects during hover for $2 m$ trees.

During the experiment pilots were asked that how they estimated the distance and the speed. They made use of the height of the trees, optical flow and distance between the trees in order to estimate the distance. Also, they used optical flow and height of the tree information for speed estimation.

The pilots' comments triggered another question: If they were using optical flow for estimating the distance, speed estimation of the pilot would have affected the distance 
estimation. Therefore, speed and distance estimation data were analyzed. Of $72 \%$ of the 160 runs pilots under estimated the speed. Also, $74 \%$ of the 160 runs (118 runs) they overestimated the distance and $60 \%$ of those (71 runs), the underestimation was more than $25 \%$ (over the $500 \mathrm{~m}$ ). Further analysis was done to check the assumption that if the pilot had estimated the speed correctly they would have estimated the distance accurately. Estimated speed was multiplied with the flight time and $2000 \mathrm{~m}$ was subtracted from this data. In this case, in $51 \%$ of the 160 runs ( 82 runs) the distance was over $2 \mathrm{~km}$ which is an indication that the median of the distribution is properly located. However, in $71 \%$ of those runs (60 runs) the estimated distance was over $2500 \mathrm{~m}$ indicating that the distribution has heavy tails. Therefore, we conclude that speed estimation alone cannot explain underestimating distance.

\subsection{Questionnaire Results}

The results of the pre-questionnaire, pilot score and post-questionnaire are discussed below.

\subsubsection{Pre-Questionnaire Result}

The age, flight hour and last flight time information is collected. They are summarized in Table 6. Flight hour data is used to correlate performance with previous experience of the pilot. The results of correlation analysis are listed at Table 7 and Table 8. Only correlation of flight hour with AT performance at hover was significant. The other correlations for flight hour were not significant. Also, simulator flight hour data and performance correlation was calculated.

Table 6 Age, Flight Hour and Last Flight Time of Participants

\begin{tabular}{lccc}
\hline & Age & Flight Hour & Last Flight(days ago) \\
& & & \\
\hline Mean & 28.9 & 1072 & 4.2 \\
SD & 1.3 & 292.4 & 2 \\
Range & $26-33$ & $580-1700$ & $1-7$ \\
\hline
\end{tabular}




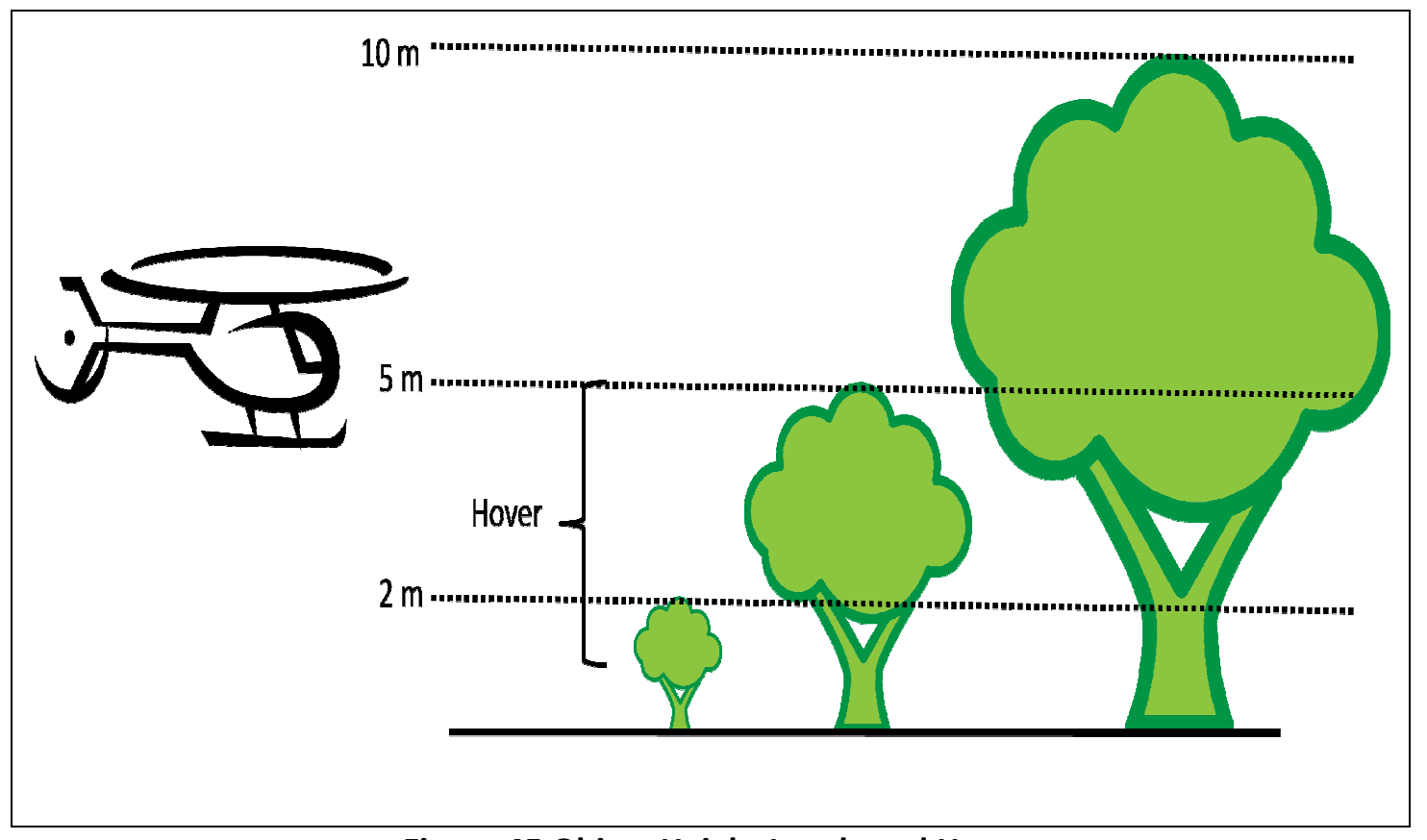

Figure 45 Object Height Levels and Hover

As shown in Table 7, AT for low altitude flight performances are negatively and slightly correlated with flight hours of the pilots. The more experienced pilots control the helicopter better. However, AT for hover positively correlated with the pilot experience. There was weak positive correlation between SEE and pilot experience. The pilots who flew less perform better at vertical hovering and SEE. DT and DEE with flight hour correlation were too weak.

As depicted in Table 8, DT performance for hover was negatively correlated with the simulator flight hour. Pilots who flew at simulator longer control the helicopter better at horizontal dimension. DEE was positively and slightly correlated with simulator flight hour. Pilots flew on a simulator shorter more accurately estimated the distance. Other correlation values for simulator flight hour were too poor to make a comment on.

Participants were asked that which helicopter they have most frequently used. This data is presented in Table 9. The flight performance is correlated with helicopter type and no observable pattern is found. 
Table 7 Correlation Coefficient of Flight Hours with Performance

\begin{tabular}{|c|c|c|c|c|c|}
\hline & $\begin{array}{c}\text { DT } \\
\text { (Hover) }\end{array}$ & $\begin{array}{c}\text { AT } \\
\text { (Hover) }\end{array}$ & $\begin{array}{c}\text { DEE } \\
\text { (L.A.F.) }\end{array}$ & $\begin{array}{c}\text { AT } \\
\text { (L.A.F.) }\end{array}$ & $\begin{array}{c}\text { SEE } \\
\text { (L.A.F.) }\end{array}$ \\
\hline $2 m$ & 0,745557 & 0,392072 & $-0,0325807$ & $-0,147849$ & $-0,050391$ \\
\hline $5 m$ & 0,202704 & $-0,16394$ & $-0,1149307$ & $-0,266756$ & 0,417279 \\
\hline $10 \mathrm{~m}$ & 0,664113 & 0,46417 & $-0,0162610$ & $-0,17677297$ & 0,399341 \\
\hline mixture & 0,14186 & $-0,11532$ & $-0,0836969$ & $-0,4388191$ & 0,351179 \\
\hline 36 opkm² & 0,592412 & 0,092338 & $-0,0081544$ & $-0,4625775$ & 0,436079 \\
\hline 144 opkm ${ }^{2}$ & 0,701514 & 0,158221 & $-0,0075452$ & $-0,3087696$ & 0,380311 \\
\hline 576 opkm² & 0,373632 & 0,011659 & $-0,1556101$ & 0,02084059 & 0,275812 \\
\hline 1296 opkm $^{2}$ & 0,192491 & 0,009744 & $-0,1323818$ & $-0,0678738$ & $-0,020861$ \\
\hline Overall & 0,081090 & 0,530243 & $-0,0535445$ & $-0,3212462$ & 0,3083489 \\
\hline
\end{tabular}

Table 8 Correlation of Simulator Usage and Performance

\begin{tabular}{|c|c|c|c|c|c|}
\hline & $\begin{array}{c}\text { DT } \\
\text { (Hover) }\end{array}$ & $\begin{array}{c}\text { AT } \\
\text { (Hover) }\end{array}$ & $\begin{array}{c}\text { DEE } \\
\text { (L.A.F.) }\end{array}$ & $\begin{array}{c}\text { AT } \\
\text { (L.A.F.) }\end{array}$ & $\begin{array}{c}\text { SEE } \\
\text { (L.A.F.) }\end{array}$ \\
\hline $2 m$ & 0,118701 & $-0,27474$ & 0,42328713 & 0,2576394 & $-0,111143$ \\
\hline $5 m$ & $-0,30968$ & $-0,41941$ & 0,3244459 & $-0,2334090$ & 0,168594 \\
\hline $10 \mathrm{~m}$ & 0,212388 & $-0,15573$ & 0,3250438 & 0,0679334 & 0,341779 \\
\hline mixture & $-0,31827$ & $-0,57345$ & 0,2957502 & $-0,4203722$ & 0,348904 \\
\hline 36 opkm² & $-0,17769$ & $-0,60204$ & 0,3848824 & $-0,2161151$ & 0,247877 \\
\hline 144 opkm² & $-0,00230$ & $-0,376100$ & 0,4613534 & 0,2296451 & 0,190131 \\
\hline 576 opkm² & $-0,30295$ & $-0,53538$ & 0,21535701 & $-0,3391823$ & 0,131400 \\
\hline 1296 opkm & $-0,0135$ & $-0,44201$ & 0,50075190 & $-0,4105705$ & 0,104235 \\
\hline Overall & $-0,480468$ & $-0,095593$ & 0,3495787 & $-0,106944$ & 0,205532 \\
\hline
\end{tabular}

Table 9 Most Frequently Used Flight Helicopter Type

\begin{tabular}{cc}
\hline Type & Participant \\
\hline UH1 & 4 \\
S70 & 2 \\
AS532 & 3 \\
AHIP & 2 \\
\hline
\end{tabular}

Moreover, pre-questionnaire included the participants' simulator experience and their ideas about the simulator fidelity and usage areas of simulators. Seven of ten participants thought that flight simulators are realistic. All participants used a simulator before the 
experiment. Six of them had used Microsoft ${ }^{\circledR}$ Flight Simulator. All of them flew with UH-1 simulator located at Kara Havacilı Okulu (Mean $=84.5$ hours). Only two participants deemed simulator appropriate for helicopter training. They thought that flight simulators can be used for emergency, instrument and flight training.

\subsubsection{Pilot Score Result}

Subjective pilot scores regarding the ability to hovering and low altitude flight based on the object density and object height were recorded. These scores will be analyzed separately in the following section.

\section{Hover:}

After each hover flight run was complete, participants were asked the following question in written format: "How adequate is the scenery for suitability to "hovering'?" The rating scale ranged from 1 = "Best for hovering" to 5 = "Worst for hovering".

An ANOVA comparison was conducted on the factors Subject, Object Density and Object Height on score (Table 30 in the Appendix).Object density ( $p=0.006, \alpha=0.05)$ and object height ( $p=0.000, \alpha=0.05$ ) have significant effects on pilot scores. However, their interaction $(p=0.229, \alpha=0.05)$ was not significant (Figure 47).

Figure 46 illustrates the main effect of score. It was shown that when the object height increased, pilot score also increased. Also, the scenes that contain mixture objects in terms of height are most suitable for hover. When we consider pilot score and performance were inversely related. Pilots perform better hovering performance (both in vertical and horizontal dimension) with small objects, whereas they ranked the scenes that contain small objects as worst scenes.

Pilot thought that the scene with the higher object density is more suitable for than lower object density. However, this increase has a peak point after which increasing the object density decrease their scores about the suitability of scene for hovering. These result in accordance with pilot performance. 


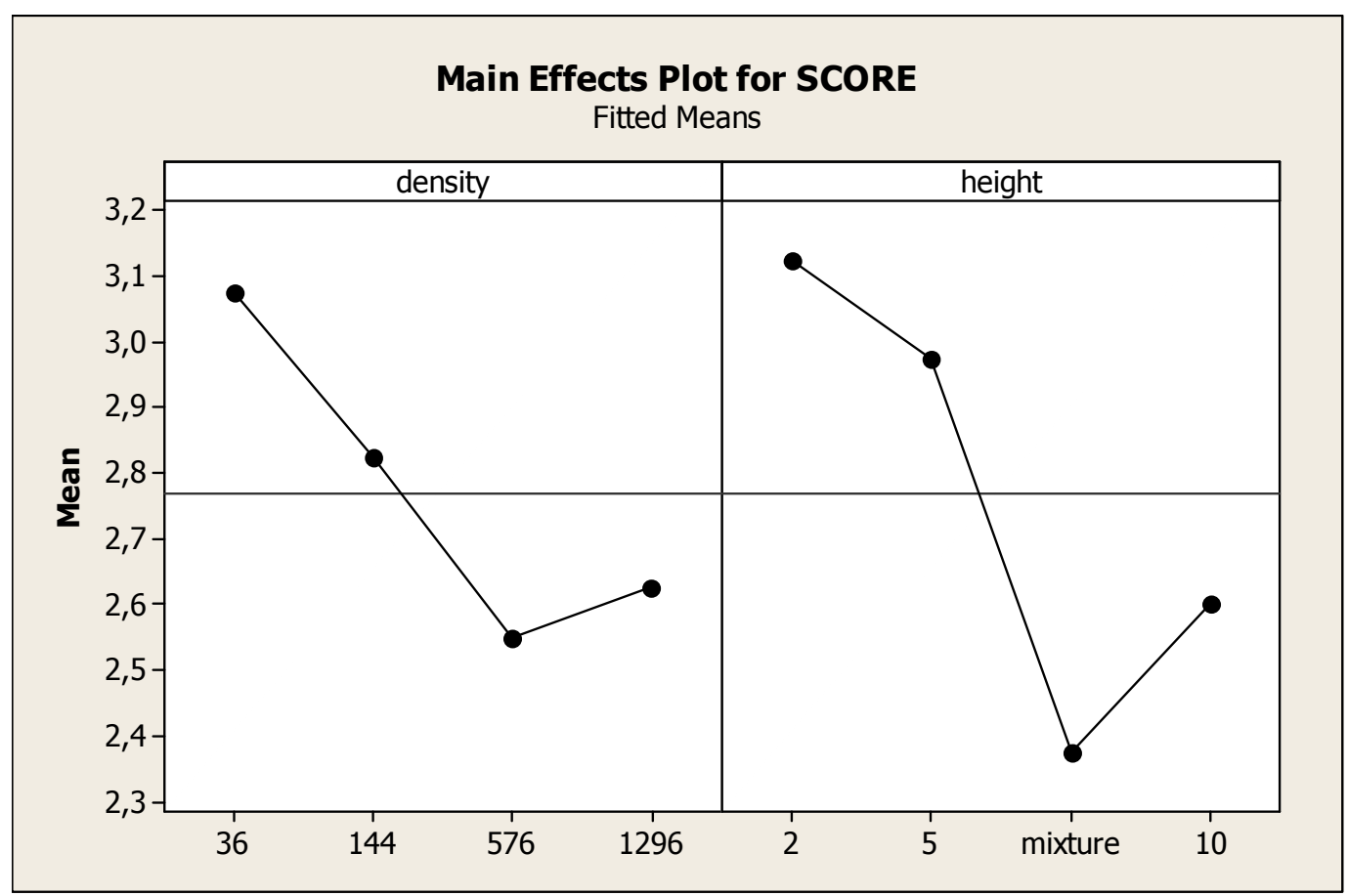

Figure 46 Hover: Main Effects Plot for SCORE versus Object Height, Object Density

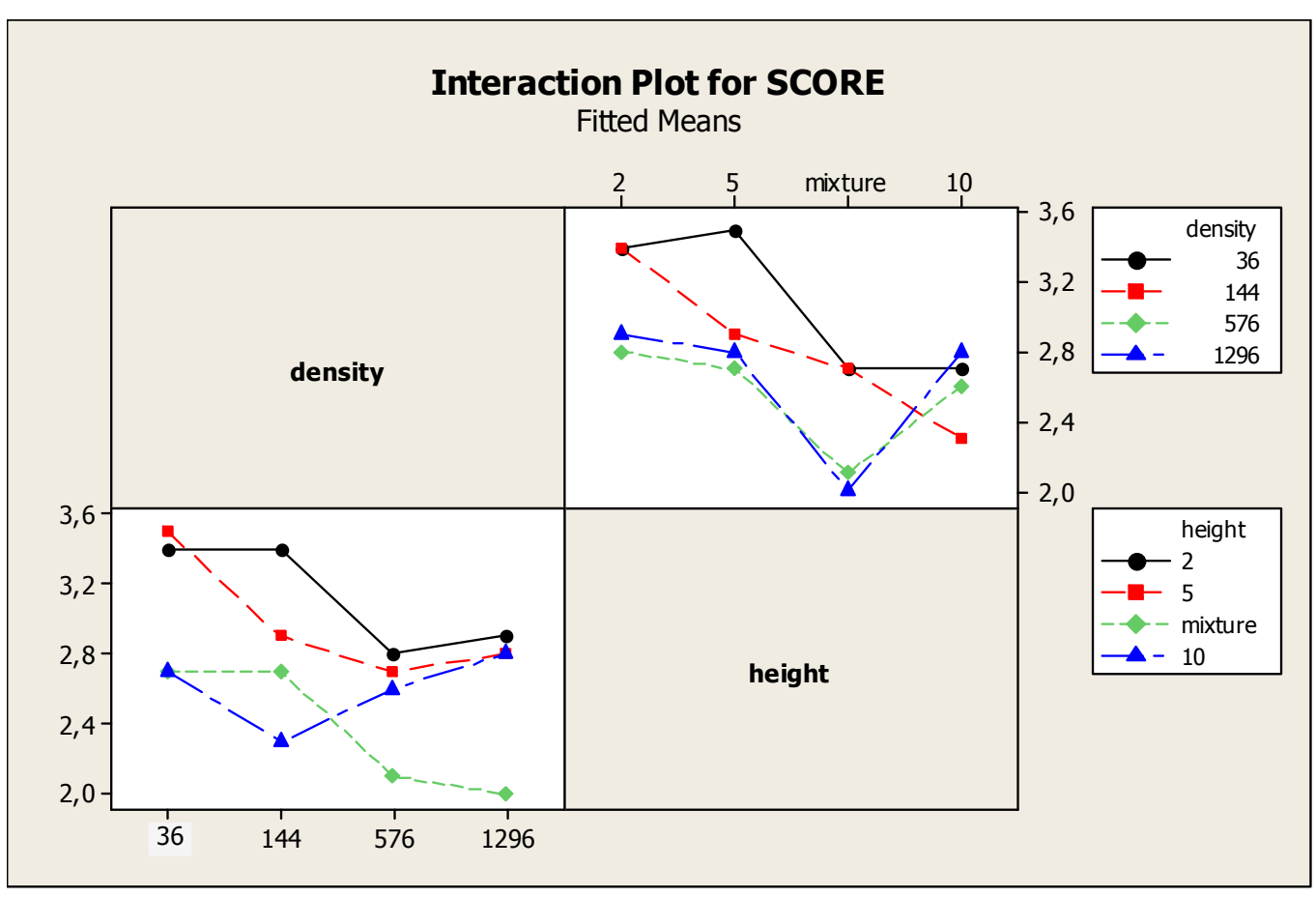

Figure 47 Hover: Interaction Plot for SCORE versus Object Height, Object Density 


\section{Low Altitude Flight:}

An ANOVA comparison was conducted on the factors Subject, Object Density and Object Height on score (Table 31 in the Appendix). Object density ( $p=0.000, \alpha=0.05)$ and object height ( $p=0.000, \alpha=0.05$ ) have significant effects on pilot scores. Interaction of them ( $p=0.716, \alpha=0.05)$, was not significant (Figure 49).

As shown in Figure 48, pilots rated scenes of $2 \mathrm{~m}$ height objects as the worst case. Furthermore, the scenes that contain mixture objects in terms of height are ranked as the best case. This was just the opposite of their performance. AT and DT performance were better with $2 \mathrm{~m}$ objects than mixture.

Pilots thought that the scene containing the higher object density is more suitable for low altitude flight than lower object density with maximum suitability of 576 objects per $\mathrm{km}^{2}$. These results are consistent with their performance. DT has a peak point at 144 objects per $\mathrm{km}^{2}$, whereas AT performance has a peak point at 576 objects per $\mathrm{km}^{2}$.

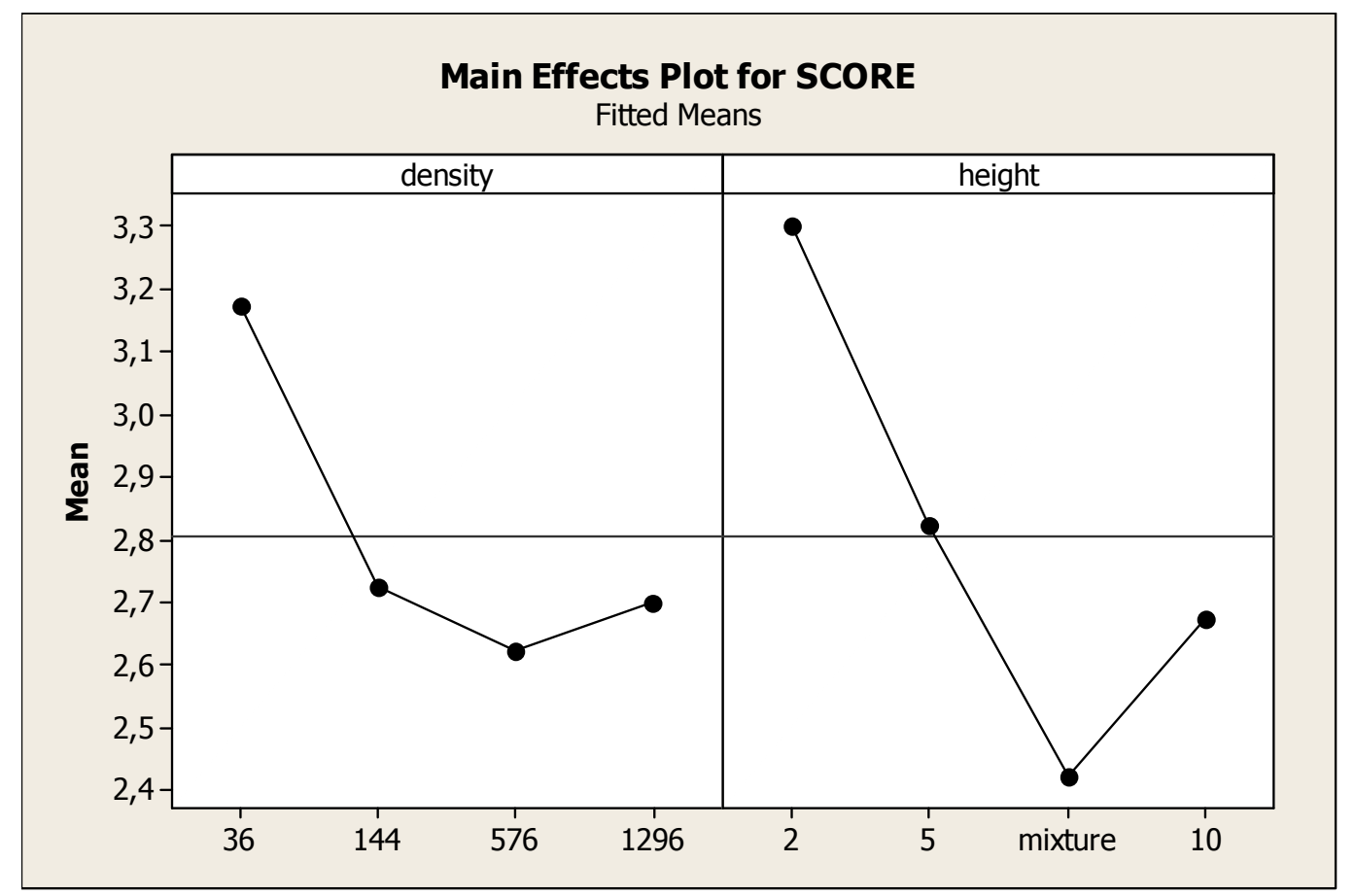

Figure 48 LAF: Main Effects Plot for SCORE versus Object Height, Object Density 


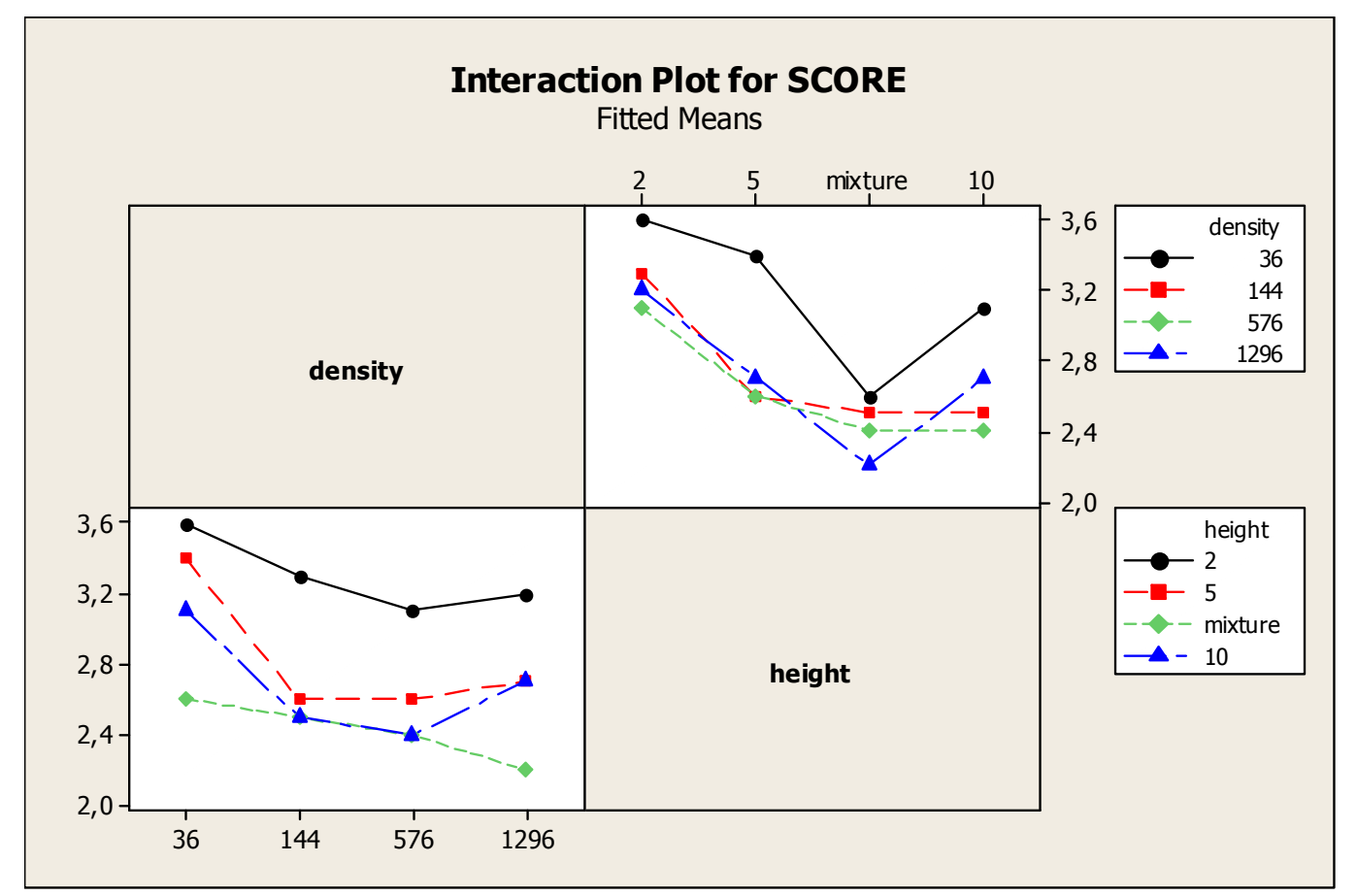

Figure 49 LAF: Interaction Plot for SCORE versus Object Height, Object Density

\subsubsection{Post-Questionnaire Result}

In order to obtain the opinion of the participants about the PC-based simulator they used during the experiment post-questionnaire was prepared. Results are summarized here.

Some of the participants mentioned lack of test platform motion and high pedal sensitivity as the weaknesses of the simulator system. Participants thought that wide FOV, scenery with mixture trees helped them during the experiment. Four participants thought that flight simulator, used in experiment, was realistic. We compared their performance with others. It was found that they were performed better at hovering along horizontal and vertical dimensions. However, there was no difference at the low altitude flight.

They were asked that if they stabilized the helicopter at scenes that contain low and high object density and small and tall objects. As shown in Table 10, most of them thought that 
they perform better with tall objects. Contrary to object height there is no such big difference between high and low object density. Almost an equal number of participants thought that they perform well with high and low density objects.

\begin{tabular}{lcc}
\multicolumn{4}{l}{ Table 10 Pilot Marks for Ability to Stabilize } & the Helicopter \\
\hline Scenery Type & Yes & No \\
\hline High density & 5 & 5 \\
Low Density & 6 & 4 \\
Tall Object & 9 & 1 \\
Small Object & 1 & 9 \\
\hline
\end{tabular}

Participants claimed that simulators can be used in flight training program for instrument, emergency, instrument flight rules (IFR). Also, they stated that the simulator used in the experiment can be used to teach visual flight rules (VFR), IFR, hover, low altitude flight, pilot selection, instrument training, emergency, and as a practice tool. 


\section{CHAPTER 5}

\section{CONCLUSION AND FUTURE WORK}

This chapter includes the main findings of the experiment and future works.

\subsection{Conclusion}

This study was conducted to determine essential OTWS visual cues for hovering and low altitude flight. Density and height parameters of 3D objects were investigated. Ten professional pilots participated to the experiment. A PC-based flight simulator was used with the wide FOV and a flight control set composed of stick, collective and cyclic. Horizontal and vertical stabilization performances of the pilots were evaluated for hover. In low altitude flight, in addition to horizontal and vertical stabilization, distance and speed estimation performances were evaluated. Also, pilots scored the each scene according to their suitability for hover and low altitude flight. Furthermore, a pro-questionnaire and post-questionnaire were conducted to determine the pilots' attitude on flight simulators.

The result of the experiment summarized at Table 11, Table 12 and Table 13. In Table 11 and 12 significant factors for the performance were marked with $v$. Results are given for 4 (object density)*3(object height) levels and 4 (object density)*4(object height) levels separately. Speed estimation was not effected from the object density, object height and their interaction. Therefore, it does not exist on the tables. In Table 13, negative and positive correlations were marked with "-" and "+", respectively. 
The detailed tables that include the ANOVA results are given in the Appendix $\mathrm{H}$ (Table 32, Table 33 and Table 34 in the Appendix).

The abbreviations used in the Table 11, 12 and 13 are explained below.

LAF: Low altitude flight,

D: Density,

H: Height,

$\mathrm{D}^{*} \mathrm{H}$ : Interaction of the density and height.

Table 11 Summary of the DT and AT Performances for Hover

\begin{tabular}{|c|c|c|c|c|c|c|c|c|c|c|c|c|}
\hline & \multicolumn{3}{|c|}{$\mathrm{DT}^{*}(4 * 3)$} & \multicolumn{3}{|c|}{$\mathrm{AT}(4 * 3)$} & \multicolumn{3}{|c|}{$\mathrm{DT}^{*}(4 * 4)$} & \multicolumn{3}{|c|}{ AT( $4 * 4)$} \\
\hline & D & $\mathrm{H}$ & $D^{*} H$ & D & $\mathrm{H}$ & $D^{*} \mathrm{H}$ & D & $\mathrm{H}$ & $D^{*} H$ & D & $\mathrm{H}$ & $D^{*} H$ \\
\hline Hover & V & V & & & V & & & & & & V & \\
\hline
\end{tabular}

Table 12 Summary of the DEE and AT Performances for Low Altitude Flight

\begin{tabular}{cccc|ccc|ccc|ccc}
\hline & \multicolumn{4}{c}{ DEE*(4*3) } & \multicolumn{3}{c}{ AT(4*3) } & \multicolumn{4}{c}{ DEE*(4*4) } & \multicolumn{3}{c}{ AT(4*4) } \\
\hline & D & H & D*H & D & H & D*H & D & H & D*H & D & H & D*H \\
LAF & & & $V$ & & V & & & & $V$ & & $V$ & \\
\hline
\end{tabular}

Table 13 Summary of the Correlation Analysis Between Performace and Experience

\begin{tabular}{lc|c|c|cc}
\hline & DT(Hover) & AT(Hover) & DEE(LAF) & AT(LAF) & SEE(LAF) \\
\hline Flight Hour & & + & & - & + \\
Simulator Usage & - & & + & & \\
\hline
\end{tabular}

After analyzing the results of the experiment and questionnaire, the following conclusions are drawn for hover and low altitude flight.

\section{Hovering:}

Results revealed that horizontal and vertical hovering performance was significantly affected by object density and object height, but not their interaction. 
Pilots performed better at high object densities and the best was 576 objects per $\mathrm{km}^{2}$. This result was consistent with the pilot score. Pilots preferred dense scenes for hovering. Also, the results of the both pilots score and performance revealed that there is a peak point at 576 objects per $\mathrm{km}^{2}$ object density. Up to this density, performance of the pilots increased. However, after this point performance did not increase, they even decreased. This shows that the dense scenes are more suitable for hover unless they make the movement difficult.

Pilots flied better with small objects: best was with $2 \mathrm{~m}$ height object. The reason for the advantage of the small object can be result of the flight type in terms of the required altitude. Hover is performed between 1 to $5 \mathrm{~m}$ and $2 \mathrm{~m}$ height objects could provide strong cues. Furthermore, pilots instinctively became close to the small objects due to their training. This situation can contribute to the advantage of the small and relatively dense scenes. Pilots can close the objects in the scene with small objects and control the position of the helicopter more accurately.

In addition, pilots' score for the scene suitability for hover and their performance in the scene conflicted for the object height. While pilots performed better with small objects, they preferred the tall objects and especially mixture ones. The scenes consisting of the mixture objects have diversity. This might have affected the pilots' views.

Experiences of the pilots in terms flight hours and simulator usage affected their performance differently for various tasks. There was a positive correlation between total flight hour and vertical hover flight. This means that less experienced pilots had better vertical hovering performance. This can be concluded that adaptation of the experienced pilots to the simulator was more difficult than less experienced ones. Although the flight hours and horizontal hover performance correlated slightly and positively, its' effect was not dominant. Horizontal hovering performance and simulator usage, on the other hand, were negatively correlated. The pilots who used flight simulator longer controlled the altitude better. 
Result of this experiment is consistent with the result of Peitso (2002) in the sense that horizontal hovering improves with increased object density. However, Peitso (2002) claimed this increase is continuous whereas we found that increasing the object density beyond 576 objects per $\mathrm{km}^{2}$ decrease performance. It has to be noted that the objects (about $60 \mathrm{~cm}$ ) they used were smaller than our objects which were $2 \mathrm{~m}$ to $10 \mathrm{~m}$. As for the vertical hovering performance, no study was found in the literature.

\section{Low Altitude Flight:}

There was a learning effect trend on pilots' altitude travelled performances. The pilots' stabilization improved throughout the experiment. This effect was ignored during the analysis phase. Vertical stabilization performance of the pilots was significantly affected by object height but not with their density. When the object height was increased, altitude stabilization performance decreased. Pilot score for low altitude flight indicated that tall and mixture objects are more suitable but they performed better with small objects.

Pilots' distance estimation was significantly affected by the interaction of the object density and height. They estimated the distance more accurately with $2 \mathrm{~m}$ height objects. However, stand alone object density and object height did not affect the performance significantly. Furthermore, object density, object height and their interaction did not affect the speed estimation significantly.

In general, pilots flied more than the desired $2 \mathrm{~km}$ and underestimated their speed. The effect of the inaccurate speed estimation on the distance judgments was analyzed. Results revealed that there was no considerable effect of the speed estimation on the distance judgment performance.

Correlation analysis revealed that experienced pilots better at altitude stabilization. However, less experienced pilots estimate the speed more accurately. Also, simulator flight hour was positively and slightly correlated with the distance estimation performance. 
Result of low altitude flight experiment is consistent with the previous studies conducted by De Maio (1983), Kleiss (1992) and Pongracic (2003) regarding the importance of object density on altitude perception. They conducted experiments at 100-150 feet altitude and 400-600 knot speeds, whereas hover is performed at 3-15 feet with zero speed. They all stated that object density has positive effect on altitude perception and approximately 4 objects per $\mathrm{km}^{2}$ was sufficient for altitude perception. Increasing the object density does not improve the performance significantly. Although the object density effect we found was not significant at $\alpha=0.05$ level numerically, it is seen in the main effects plot (Figure 38 ) that the altitude perception was consistently improving with increased object density.

The findings of our study can guide developers in design and development phases of flight simulators. They can design simulators that will provide the needed detail with lowest complexity. In this way, the cost of the simulator for a given flight task can be optimized. A balance between effectiveness and time/cost efficiency will be achieved.

Training designers, on the other hand, will profit from these results when preparing an aviation training program. They can arrange the OTWS for a task using the result of this experiment. For example, at the beginning of the training the scenes that have small objects can be constructed. After pilots feel comfortable with the small objects, the scenes composed of the taller objects and more difficult scenes can be shown to the pilots.

\subsection{Future Work}

As mentioned in Chapter 2, this study covered the navigation part on pilot group of the framework. The remaining parts that include non-pilot, hobbyist at static image, dynamic image and navigation tasks should be investigated. Also, the pilot group could be tested at static and dynamic image tasks.

This study analyzed the static objects only in terms of density, height and uniformity. Effects of stationary objects on hovering and low altitude flight should be analyzed according to their distribution on the scenery: random or uniform. Also, discrimination can be an important cue. For example, scene containing a different color tree can be compared 
with scene composed of same color trees. Similarly, height mixture was tried for only equal height priors, different variations can have different effects. The effect of moving objects on hover and low altitude flight should be investigated.

The corner and edge information of the objects can affect the flight performance. Therefore, objects that have no edge and corner should be investigated. Conic, tetrahedron and tree (from low-detailed to high-detailed) should be compared in further studies.

In low altitude flight altitude travelled data was calculated for the points that were above the $1 / 2 *$ maximum altitude. Calculation with the other criteria such as points above the $2 *$ height of the tree in the scene could be done. Also, altitude estimation of the pilot should be recorded and compared with the calculated data.

We found that object density and height significantly affected both horizontal and vertical hovering performance. Interaction of the terrain shape with the object density and height are not investigated yet.

In this study wide FOV was used. Narrow FOV can be compared with wide FOV. Also, 19" LCD monitors was used in the experiment. Other display type i.e. Head Mounted Display (HMD) can be used and their effect should be investigated.

During the experiment, eye gaze of the participants was recorded by a stereo camera set. This data was not analyzed in this study. A further study will be conducted to analyze the eye tracking data. 


\section{REFERENCES}

AOPA 1998, 'Personal computer-based training is making good pilots better', in Safety Advisor, No. 2., Aircraft Owners and Pilots Association (AOPA).

ASME International (the American Society of Mechanical Engineers). (2000).The Link Flight Trainer [Brochure].Binghamton, New York: Joseph De Angelo, P.E.

Authorities, J. A. (1999). Joint Aviation Requirements- Simulator Training Devices (JAR-STD) $1 \mathrm{H}$. Helicopter Flight Simulators. Netherlands: JAA Regulations Division.

Bigham, D. D. (2000). Distance Perception and Visualization Using Virtual Environments. Naval Postgraduate School, Monterey, CA.

Bruce Artwick (2008). Flight Simulator History Retrieved June 11,, 2008, from http://fshistory.simflight.com/fsh/artwick.htm

Chung, W. (2000). A review of approaches to determine the effectiveness of ground-based flight simulation. Paper presented at the AIAA Modeling and Simulation Technologies Conference.

Chung, W., Sweet, B., Kaiser, M., \& Lewis, E. (2003). Visual Cueing Effects Investigation for a Hover Task. Proceedings of the AIAA Modeling and Simulation Technologies Conference, 1114, 2003-5524.

D'Alessandro, N. (2007). Transfer_PCATDs_aviation_training_learning_v1-1.pdf . Retrieved January 20, 2008 from

http://www.insitesolutions.com.au/Documents/Transfer_PCATDs_aviation_\%20training_le arning_v1-1.pdf

Faul, F., Erdfelder, E., Lang, A.-G., \& Buchner, A. (2007). G*Power 3: A flexible statistical power analysis program for the social, behavioral, and biomedical sciences. Behavior Research Methods, 39, 175-191. 
Flight Gear. (2008). Introduction. Retrieved February 11, 2008 from http://www.flightgear.org/introduction.html

Forsell, C. (2007). Perceptually Motivated Constraints on 3D Visualizations. Uppsala University, Uppsala.

Johnson, D., \& Stewart II, J. (2005). Utility of a Personal Computer-Based Aviation Training Device for Helicopter Flight Training. International Journal of Applied Aviation Studies, 5(2), 287-305.

Johnson, W., Schroeder, J., Center, N., \& Field, M. (1995). Visual-motion cueing in the control of altitude. Paper presented at the Systems, Man and Cybernetics.'Intelligent Systems for the 21st Century'., IEEE International Conference.

Karaahmetoglu. (2005). Out-the window scene properties in pc-based helicopter simulators. METU Modelling and Simulation, Ankara, Turkey.

Karaahmetoğlu, C., Yilmaz, E., Yardimci Cetin, Y., \& Köksal, G. (2006). Out-the-window scene properties in pc-based helicopter simulators. Proceedings of SPIE, 6226, 622600.

Keller, M., Schnell, T., Lemos, K., Glaab, L., \& Parrish, R. (2003). Pilot performance as a function of display resolution and field of view in a simulated terrain following flight task using a synthetic vision system. Paper presented at the Digital Avionics Systems Conference, 2003. DASC'03. The 22nd.

Kleiss, J. (1990). Terrain Visual Cue Analysis for Simulating Low-Level Flight: A Multidimensional Scaling Approach. Dayton, OH: Univesity of Dayton Research Institue.

Kleiss, J. (1992). Tradeoffs among types of scene detail for simulating low-altitude flight. Paper presented at the Systems, Man and Cybernetics, 1992., IEEE International Conference on.

Kleiss, J. (1995). Perceptual Dimensions of Simulated Scenes Relevant for Visual LowAltitude Flight. Dayton, OH: University of Dayton Research Institue.

Kleiss, J., \& Hubbard, D. (1995). Effect of Terrain Shape and Object Grouping on Perception of Change in Altitude in a Flight Simulator. Dayton, OH: University of Dayton Research Institue.

Lemos, K., Schnell, T., Etherington, T., Vogl, T., \& Postikov, A. (2003). Synthetic vision systems: human performance assessment of the influence of terrain density and texture. Paper presented at the Digital Avionics Systems Conference, 2003. DASC'03. The 22nd.

Macchiarella, ND, \& Brady, T. (2006), 'Innovations in Ab Initio Pilot Training: An Application of High Fidelity Flight Training Devices'. Proceedings of the Flight Simulation Group Committee of the Royal Aeronautical Society: Cutting Costs in Flight Simulation: Balancing Quality and Capability. London. UK. 
MCAllister, F. D. (1993). Stereo Computer Graphics. New Jersey: Princeton University Press.

McDermott, J. (2006). Computer-Based Flight Simulation: A Cost Effective Way for General Aviation Pilots to Improve Their Instrument Proficiency. International Journal of Applied Aviation Studies, 6(1), 155-163.

Microsoft. (2008). Microsoft Flight Simulator Retrieved February 10, 2008, from http://www.microsoft.com/games/flightsimulatorX/default.htm

Miller, J., Daly, J., Wood, M., Roper, M., Brooks, A.(1997) Statistical power and its subcomponents -- missing and misunderstood concepts in empirical software engineering research, Information and Software TechnologyVolume 39, Issue 4, , April 1997, Pages 285295.

Montgomery, D. C. (1996). Design and Analysis of Experiments. New York: John Wiley\&Sons.

Murphy, K. R., \& Myors, B. (2004). Statistical Power Analysis: A Simple and General Model for Traditional and Modern Hypothesis Test. New Jersey: Lawrence Erlbaum Associates.

Naikar, N. (1998). Perspective Displays: A Review of Human Factors Issues. Melbourne Victoria: DSTO Aeronautical and Maritime Research Laboratory.

Peitso, L. (2002). Visual Field Requirements for Precision Nap-of-the-Earth Helicopter Flight. Naval Postgraduate School, Monterey, CA.

Pongracic, H., D., M., \& T., T. (1997). Issues in Cost-Effectiveness and Fidelity of Simulation. Paper presented at the International SimTecT Conference.

Pongracic, H., Doman, J., Grabovac, M., Yildiz, J., \& Smith, S. (2003). An initial investigation into visual cues for altitude perception in terrain following flight. Paper presented at the SimTecT.

Rosco, S. N. (1971). Incremental transfer effectiveness. Human Factors, 13, 561-567.

Schnell, T., \& Katherine Lemos, S. (2002). Terrain Sampling Density and Texture Requirements for Synthetic Vision Systems. lowa City, IA: Center for Computer Aided Design, Operator Performance Laboratory (OPL), The University of lowa,.

Stanton, N. (1996). Simulators: a review of research and practice. In Human Factors in Nuclear Safety (pp. 117-140).

Thatcher, S., Fyfe, A., Jones, C., \& Ong-Aree, J. (2006). Preliminary investigation of education transfer from simulator to aircraft. WORLD TRANSACTIONS ON ENGINEERING AND TECHNOLOGY EDUCATION, 5(1), 83. 
Williams, B. (2006), Microsoft Flight Simulator as a Training Aid, Aviation Supplies \& Academics Inc., Newcastle WA.

Willigies, B. H. (1980). 'Measurement of transfer of training'. In Roscoe, S. N. (Ed.), Aviation psychology. Ames: lowa State University Press.

X-Plane. (2008). Description, Retrieved February 10, 2008, from http://www.xplane.com/about.html 


\section{APPENDICIES}

\section{APPENDIX A: PRE-QUESTIONNAIRE}

Cinsiyetiniz:

Yaşınız:

Toplam Uçuş Saatiniz:

Son uçuşunuz üzerinden geçen süre:

En sık uçuş yaptığınız helicopter türü:

Görme ile ilgili probleminiz var mı?

Gözlük ya da lens kullanıyor musunuz?

Uçuş simülatörlerini gerçekçi buluyor musunuz?

Uçuş Simülatörlerinin helikopter eğitimi için yeterli olduğunu düşünüyor musunuz? Açıklayınız $\square$ Kadın $\square$ Erkek

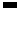

Daha once uçuş simülatörü kullandınız mı?

$\square$ Evet $\square$ Hayır

Evet ise, hangi simülatörü ne kadar süre ile kullandınız.

Simülatörlerin hangi amaçlarla kullanılabileceğini düşünüyorsunuz? 


\section{APPENDIX B: POST-QUESTIONNAIRE}

Simülatörü kullanırken sizi rahatsız eden unsurlar oldu mu? Evet, ise açıklayınız.

$\square$ Evet $\square$ Hayır

Simülatörü kullanırken size yardımcı olduğunu düşündüğünüz özellikler nelerdir?

Kullandığınız simulator uygulamasını gerçekçi buldunuz mu?

$\square$ Evet $\square$ Hayır

Helikopteri kullanırken aşağıdaki ortamlarda kontrolü sağladığınızı düşünüyor musunuz?

\begin{tabular}{|c|c|c|c|}
\hline Yoğun nesne & $\square$ Evet $\square$ Hayır & Büyük Nesne & $\square$ Evet $\square$ Hayır \\
\hline Seyrek nesne & $\square$ Evet $\square$ Hayır & Küçük Nesne & $\square$ Evet $\square$ Hayır \\
\hline
\end{tabular}

Simülatörlerin hangi eğitim aşamalarında kullanılabileceğini düşünüyorsunuz?

Deney sırasında kullandığınız simülatörn hangi amaçlarla kullanılabileceğini düşünüyorsunuz? 


\section{APPENDIX C: PARTICIPANT CONSENT FORM}

\section{GÖNÜLLÜ KATILIM FORMU}

Bu çalışma, Bilişim Sistemleri Ana Bilim Dalı Araştırma Görevlisi Yasemin Çetin'in yüksek lisans tezi kapsamında yapılan bir çalışmadır. Çalışmanın amacı, katılımcı helikopter pilotlarının havır ve alçak uçuş hareketi sırasında performansına ortamdaki 3 boyutlu nesnelerin etkisi hakkında bilgi toplamaktır. Çalışmaya katılım tamimiyle gönüllülük temelinde olmalıdır. Çalışmada, sizden kimlik belirleyici hiçbir bilgi istenmemektedir. Verileriniz tamimiyle gizli tutulacak ve sadece araştırmacılar tarafından değerlendirilecektir; elde edilecek bilgiler bilimsel yayımlarda kullanılacaktır.

Katılımcılardan çalışma öncesinde ve sonrasında anket doldurmaları istenecektir. Katılımcılardan simülasyon uygulamasında helikopteri farklı sahne düzenlerinde 2 dakika boyunca havır pozisyonunda mümkün olduğunca stabil tutması ve $2 \mathrm{~km}$ boyunca alçal irtifa uçuşu yapıp hızını tahmin etmesi beklenmektedir. Uygulamanın yaklaşık olarak 1 saat sürmesi beklenmektedir. Uygulamanın kişiler üzerinde fiziksel ya da ruhsal rahatsızlık vermesi beklenmemektedir. Ancak, simülasyon uygulaması sırasında simülatörden ya da herhangi başka bir nedenden ötürü kendinizi rahatsız hissederseniz uygulamayı yarıda bırakıp çıkmakta serbestsiniz. Böyle bir durumda çalışmayı uygulayan kişiye, simülasyon uygulamasını tamamlamadığınızı söylemek yeterli olacaktır. Simülasyon uygulaması sonunda, bu çalışmayla ilgili sorularınız cevaplanacaktır. Bu çalışmaya katıldığınız için şimdiden teşekkür ederiz. Çalışma hakkında daha fazla bilgi almak için Bilişim Sistemleri Anabilim dalı öğrencisi Ar. Gör. Yasemin Çetin (Oda: MM410; Tel: 210 3739; E-posta: ycetin@ii.metu.edu.tr) ile iletişim kurabilirsiniz.

Bu çalışmaya tamamen gönüllü olarak katılıyorum ve istediğim zaman yarıda kesip çıkabileceğimi biliyorum. Verdiğim bilgilerin bilimsel amaçlı yayımlarda kullanılmasını kabul ediyorum. (Formu doldurup imzaladıktan sonra uygulayıcıya geri veriniz).

İsim Soyad

Tarih

İmza 


\section{APPENDIX D: DE-BRIEF FORM}

\section{KATILIM SONRASI BILGI FORMU}

Bu çalışma daha önce de belirtildiği gibi ODTÜ Enformatik Enstitüsü Bilişim Sistemleri AnaBilim Dalı öğrencilerinden Yasemin Çetin'in yüksek lisans tezi kapsamında yapılmaktadır. Çalışmada ortamdaki 3 boyutlu nesnelerin pilotların havır performansına etkileri incelenecektir.

3 boyutlu nesnelerin pilotların performanslarına etkisi üzerine Kleiss(1992) ve De Maio(1983) tarafından yapılan çalışmalarda 3 boyutlu nesnelerin yoğunluk artışının, pilotların yükseklik ve düşeydeki yer değiştirme algılarında artışa yol açtığı saptanmıştır. Performanstaki bu artışın bir noktada doyum noktasına ulaşması ve bu noktadan sonra düşüşe geçmesi beklenmektedir. 3 boyutlu nesnelerin ayrıntılandırılmasının ise performans üzerinde etkisi olmadığı belirlenmiştir. 3 boyutlu nesnelerin ayrıntılandırılması aşamasında gerçek ağaç modelleri ve dörtyüzlü üçgenler kullanılmıştır. Dört yüzlü üçgenlerin köşe ve kenar bilgilerinin katılımcılara yükseklik algıları üzerinde etkide bulunduğu düşünülmektedir. Bu amaçla farklı yoğunluk ve boyuttaki 3 boyutlu nesnelerin bulunduğu sahnelerde, pilotlardan bilgisayar tabanlı simulatorü kullanmaları istenmiştir.

Bu çalışmadan alınacak ilk verilerin Ocak 2008 sonunda elde edilmesi amaçlanmaktadır. Elde edilen bilgiler sadece bilimsel araştırma ve yazılarda kullanılacaktır. Çalışmanın sonuçlarını öğrenmek ya da bu araştırma hakkında daha fazla bilgi almak için aşağıdaki isimlere başvurabilirsiniz. Bu araştırmaya katıldığınız için tekrar çok teşekkür ederiz.

Arş. Gör. Yasemin Çetin (Oda: MM410; Tel: 210 3739; ycetin@ii.metu.edu.tr)

\section{$\underline{\text { Kaynaklar }}$}

-DeMaio, J. Rinalducci, E.J., Brooks, R., Brunderman, J., Visual Cueing Effectiveness: Cornparison of Perception and Flying Performance. Proceedins of the Human Factors Society - 27th Annual Meeting 1983 (pp. 928- 932) -Kleiss, J.A., "Tradeoffs among types of scene detail for simulating low-altitude flight," Systems, Man and Cybernetics, 1992., IEEE International Conference on , vol., no., pp.1141-1146 vol.2, 18-21 Oct 1992 URL: http://ieeexplore.ieee.org/iel2/665/6720/00271635.pdf?isnumber=6720\&prod=STD\&arnumber=271635\&arnu $\underline{\text { mber }=271635 \& a r S t=1141 \& \text { ared }=1146+\text { vol } .2 \text { \&arAuthor }=\text { Kleiss\%2C+J.A. }}$. 


\section{APPENDIX E: PILOT SCORE FORM}

1-En kötü 5- En iyi

\begin{tabular}{|c|c|c|c|c|c|}
\hline \multicolumn{6}{|l|}{ Sahne 1-1: } \\
\hline Sahnenin hover için yeterliliği & 1 & 2 & 3 & 4 & 5 \\
\hline \multicolumn{6}{|l|}{ Sahne1-2: } \\
\hline Sahenenin alçak irtifa uçuşu için yeterliliği & 1 & 2 & 3 & 4 & 5 \\
\hline \multicolumn{6}{|l|}{ Uçuş hızınız } \\
\hline \multicolumn{6}{|l|}{ Sahne 2-1: } \\
\hline Sahnenin hover için yeterliliği & 1 & 2 & 3 & 4 & 5 \\
\hline \multicolumn{6}{|l|}{ Sahne2-2: } \\
\hline Sahenenin alçak irtifa uçuşu için yeterliliği & 1 & 2 & 3 & 4 & 5 \\
\hline \multicolumn{6}{|l|}{ Uçuş hızınız } \\
\hline \multicolumn{6}{|l|}{ Sahne 3-1: } \\
\hline Sahnenin hover için yeterliliği & 1 & 2 & 3 & 4 & 5 \\
\hline \multicolumn{6}{|l|}{ Sahne3-2: } \\
\hline Sahenenin alçak irtifa uçuşu için yeterliliği & 1 & 2 & 3 & 4 & 5 \\
\hline \multicolumn{6}{|l|}{ Uçuş hızınız } \\
\hline \multicolumn{6}{|l|}{ Sahne 4-1: } \\
\hline Sahnenin hover için yeterliliği & 1 & 2 & 3 & 4 & 5 \\
\hline \multicolumn{6}{|l|}{ Sahne4-2: } \\
\hline Sahenenin alçak irtifa uçuşu için yeterliliği & 1 & 2 & 3 & 4 & 5 \\
\hline \multicolumn{6}{|l|}{ Uçuş hızınız } \\
\hline \multicolumn{6}{|l|}{ Sahne 5-1: } \\
\hline Sahnenin hover için yeterliliği & 1 & 2 & 3 & 4 & 5 \\
\hline \multicolumn{6}{|l|}{ Sahne5-2: } \\
\hline Sahenenin alçak irtifa uçuşu için yeterliliği & 1 & 2 & 3 & 4 & 5 \\
\hline Uçuş hızınız & & & & & \\
\hline
\end{tabular}




\begin{tabular}{|c|c|c|c|c|c|}
\hline \multicolumn{6}{|l|}{ Sahne 6-1: } \\
\hline Sahnenin hover için yeterliliği & 1 & 2 & 3 & 4 & 5 \\
\hline \multicolumn{6}{|l|}{ Sahne6-2: } \\
\hline Sahenenin alçak irtifa uçuşu için yeterliliği & 1 & 2 & 3 & 4 & 5 \\
\hline \multicolumn{6}{|l|}{ Uçuş hızınız } \\
\hline \multicolumn{6}{|l|}{ Sahne 7-1: } \\
\hline Sahnenin hover için yeterliliği & 1 & 2 & 3 & 4 & 5 \\
\hline \multicolumn{6}{|l|}{ Sahne7-2: } \\
\hline Sahenenin alçak irtifa uçuşu için yeterliliği & 1 & 2 & 3 & 4 & 5 \\
\hline \multicolumn{6}{|l|}{ Uçuş hızınız } \\
\hline \multicolumn{6}{|l|}{ Sahne 8-1: } \\
\hline Sahnenin hover için yeterliliği & 1 & 2 & 3 & 4 & 5 \\
\hline \multicolumn{6}{|l|}{ Sahne8-2: } \\
\hline Sahenenin alçak irtifa uçuşu için yeterliliği & 1 & 2 & 3 & 4 & 5 \\
\hline \multicolumn{6}{|l|}{ Uçuş hızınız } \\
\hline \multicolumn{6}{|l|}{ Sahne 9-1: } \\
\hline Sahnenin hover için yeterliliği & 1 & 2 & 3 & 4 & 5 \\
\hline \multicolumn{6}{|l|}{ Sahne9-2: } \\
\hline Sahenenin alçak irtifa uçuşu için yeterliliği & 1 & 2 & 3 & 4 & 5 \\
\hline \multicolumn{6}{|l|}{ Uçuş hızınız } \\
\hline \multicolumn{6}{|l|}{ Sahne 10-1: } \\
\hline Sahnenin hover için yeterliliği & 1 & 2 & 3 & 4 & 5 \\
\hline \multicolumn{6}{|l|}{ Sahne10-2: } \\
\hline Sahenenin alçak irtifa uçuşu için yeterliliği & 1 & 2 & 3 & 4 & 5 \\
\hline \multicolumn{6}{|l|}{ Uçuş hızınız } \\
\hline \multicolumn{6}{|l|}{ Sahne11- 1: } \\
\hline Sahnenin hover için yeterliliği & 1 & 2 & 3 & 4 & 5 \\
\hline
\end{tabular}




\begin{tabular}{|c|c|c|c|c|c|}
\hline \multicolumn{6}{|l|}{ Sahne11-2: } \\
\hline Sahenenin alçak irtifa uçuşu için yeterliliği & 1 & 2 & 3 & 4 & 5 \\
\hline \multicolumn{6}{|l|}{ Uçuş hızınız } \\
\hline \multicolumn{6}{|l|}{ Sahne12- 1: } \\
\hline Sahnenin hover için yeterliliği & 1 & 2 & 3 & 4 & 5 \\
\hline \multicolumn{6}{|l|}{ Sahne12-2: } \\
\hline Sahenenin alçak irtifa uçuşu için yeterliliği & 1 & 2 & 3 & 4 & 5 \\
\hline \multicolumn{6}{|l|}{ Uçuş hızınız } \\
\hline \multicolumn{6}{|l|}{ Sahne 13-1: } \\
\hline Sahnenin hover için yeterliliği & 1 & 2 & 3 & 4 & 5 \\
\hline \multicolumn{6}{|l|}{ Sahne13-2: } \\
\hline Sahenenin alçak irtifa uçuşu için yeterliliği & 1 & 2 & 3 & 4 & 5 \\
\hline \multicolumn{6}{|l|}{ Uçuş hızınız } \\
\hline \multicolumn{6}{|l|}{ Sahne 14-1: } \\
\hline Sahnenin hover için yeterliliği & 1 & 2 & 3 & 4 & 5 \\
\hline \multicolumn{6}{|l|}{ Sahne14-2: } \\
\hline Sahenenin alçak irtifa uçuşu için yeterliliği & 1 & 2 & 3 & 4 & 5 \\
\hline \multicolumn{6}{|l|}{ Uçuş hızınız } \\
\hline \multicolumn{6}{|l|}{ Sahne15- 1: } \\
\hline Sahnenin hover için yeterliliği & 1 & 2 & 3 & 4 & 5 \\
\hline \multicolumn{6}{|l|}{ Sahne15-2: } \\
\hline Sahenenin alçak irtifa uçuşu için yeterliliği & 1 & 2 & 3 & 4 & 5 \\
\hline \multicolumn{6}{|l|}{ Uçuş hızınız } \\
\hline \multicolumn{6}{|l|}{ Sahne 16-1: } \\
\hline Sahnenin hover için yeterliliği & 1 & 2 & 3 & 4 & 5 \\
\hline \multicolumn{6}{|l|}{ Sahne16-2: } \\
\hline Sahenenin alçak irtifa uçuşu için yeterliliği & 1 & 2 & 3 & 4 & 5 \\
\hline Uçuş hızınız & & & & & \\
\hline
\end{tabular}




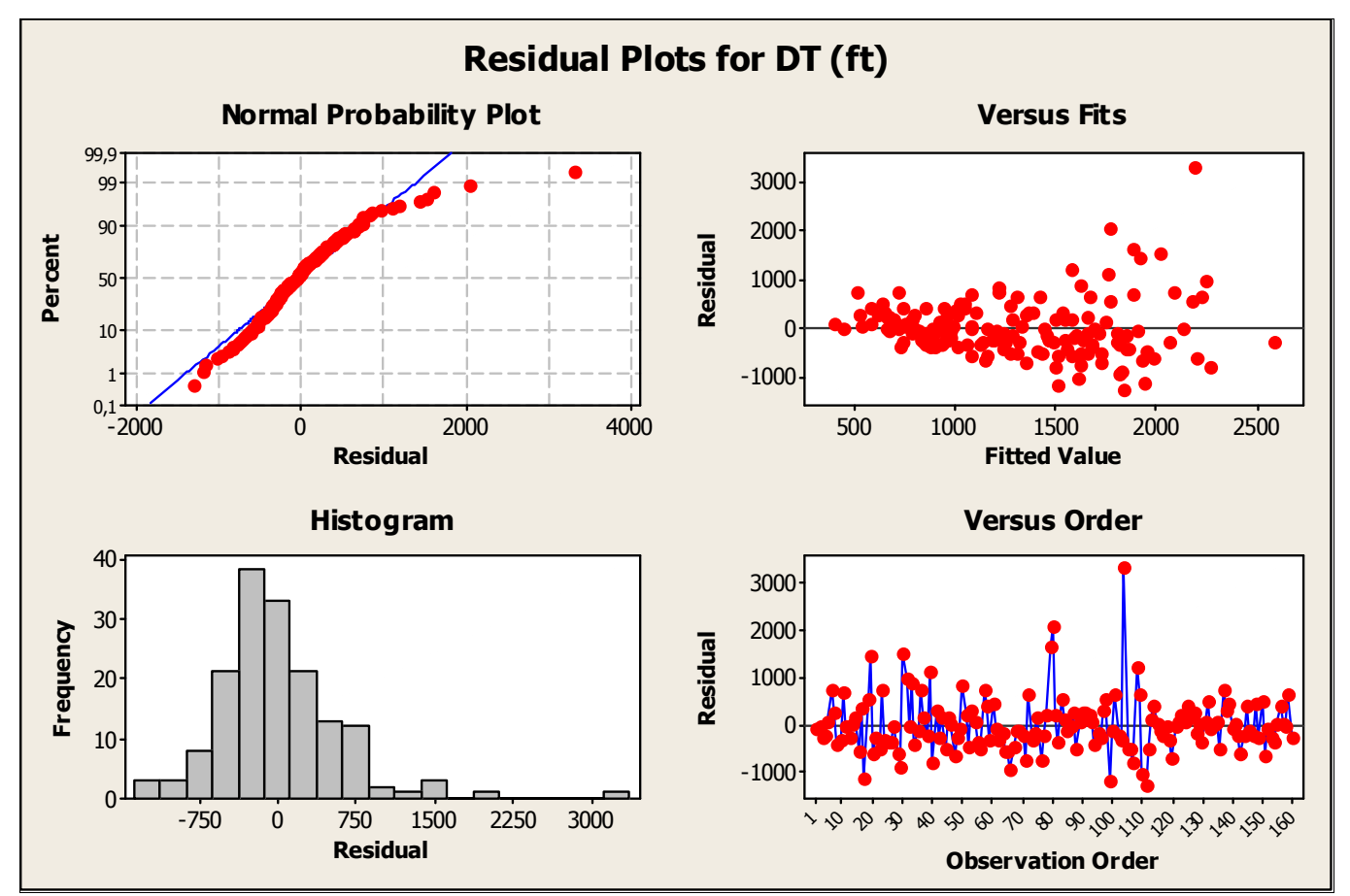

Figure 50 Hover: Residual Plots for DT (4 Object Density *4 Object Size)

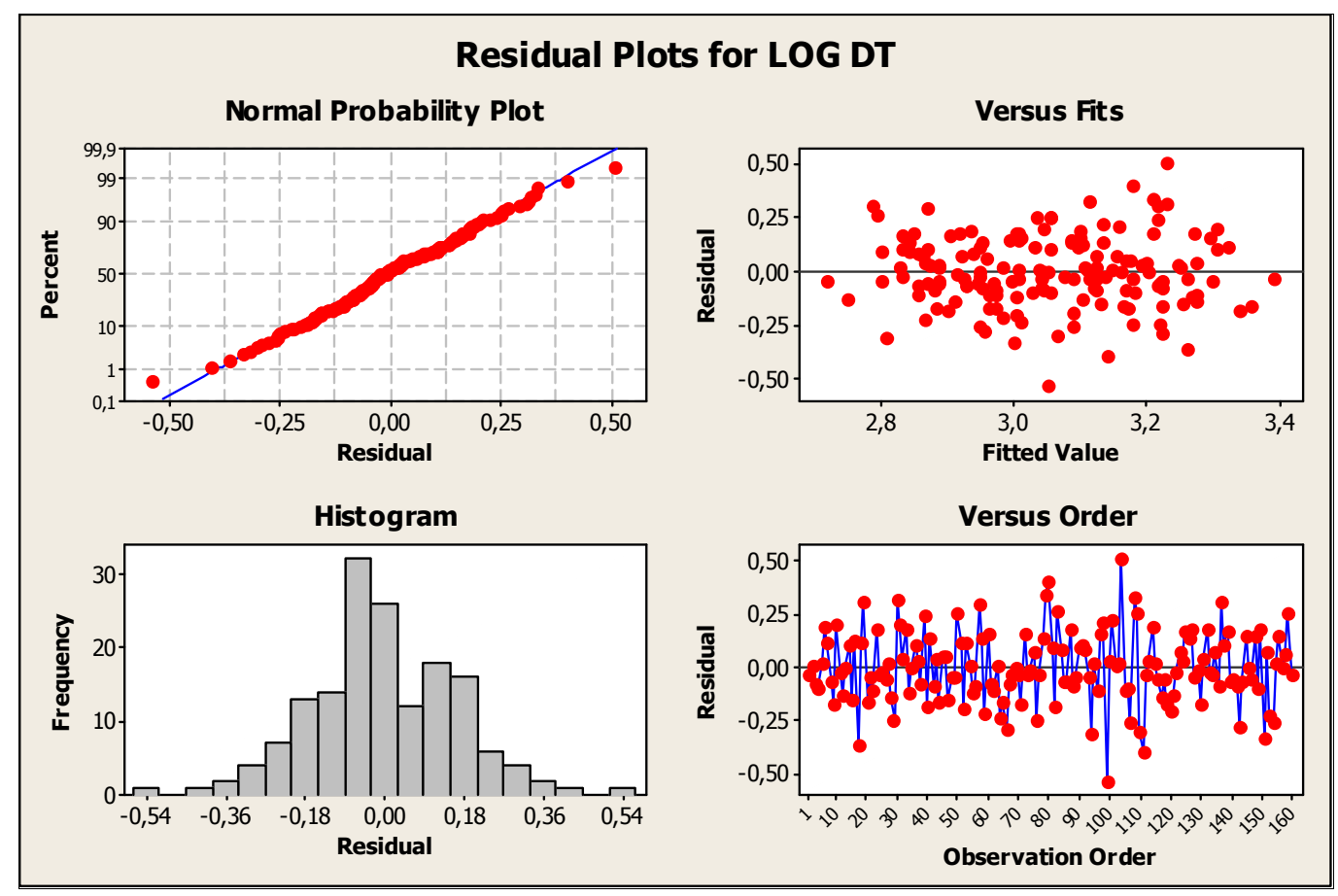

Figure 51 Hover: Residual Plots for LOG DT (4 Object Density *4 Object Size) 


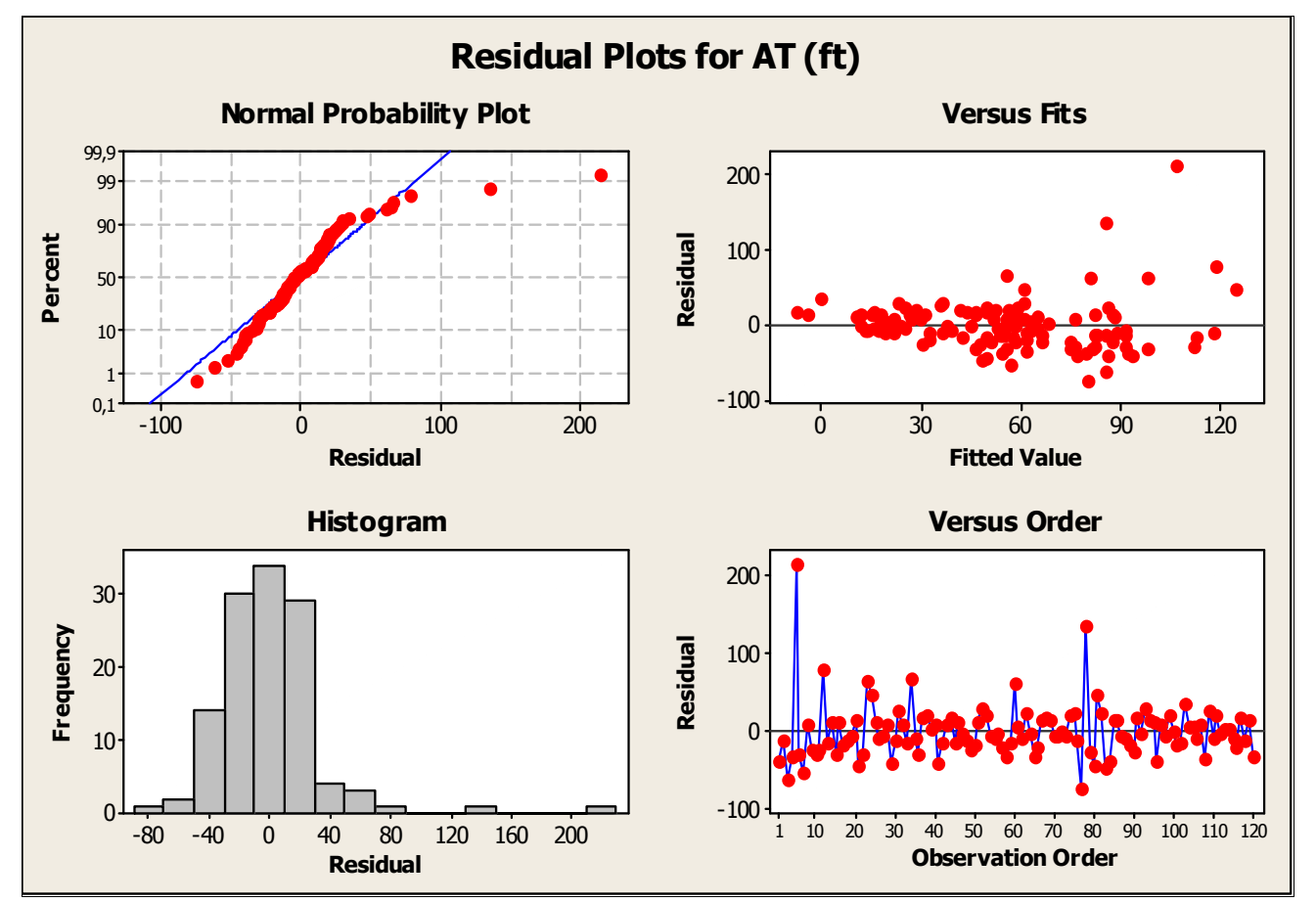

Figure 52 Hover: Residuals Plot for AT (4 Object Density *3 Object Size)

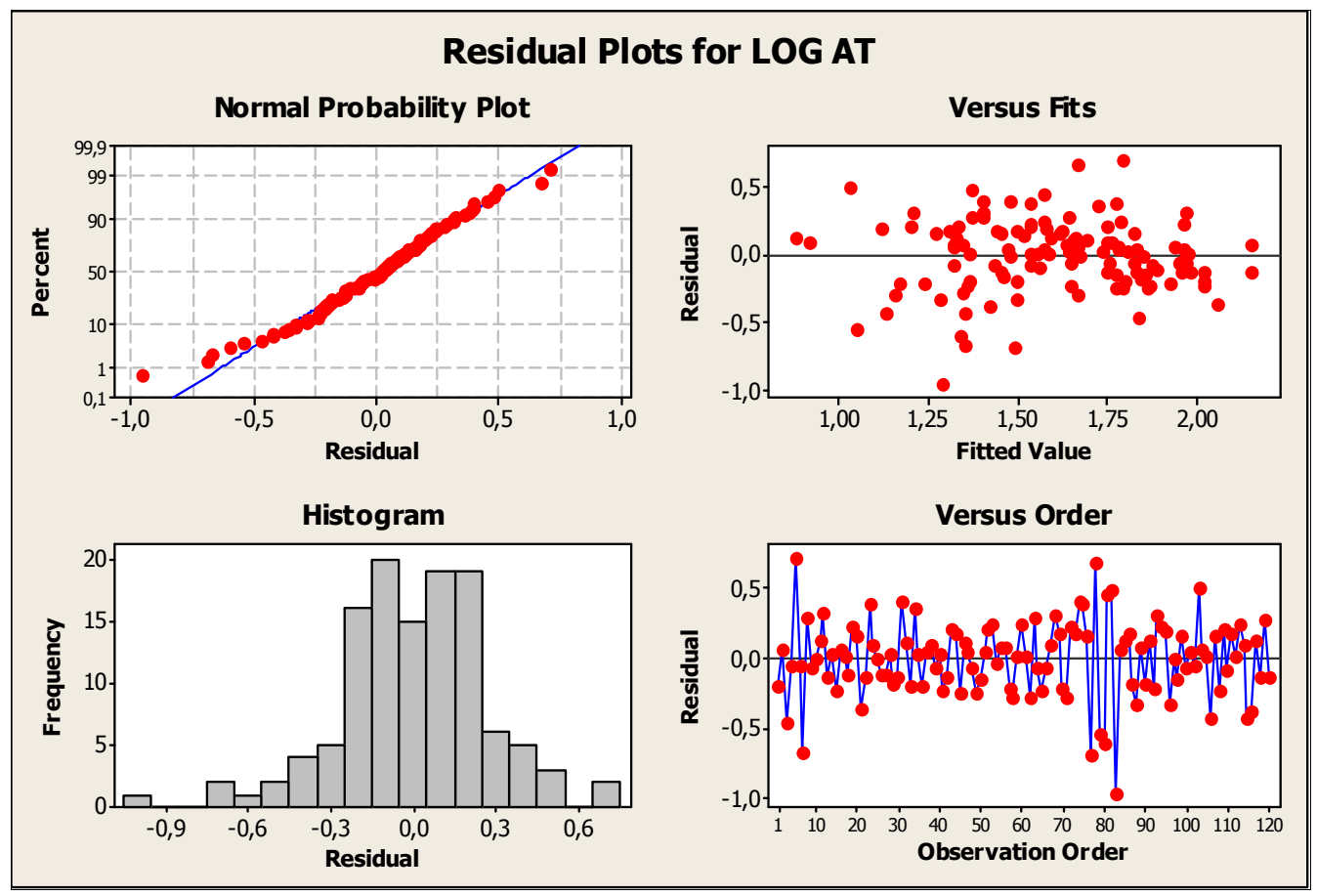

Figure 53 Hover: Residuals Plot for LOG AT (4 Object Density *3 Object Size) 


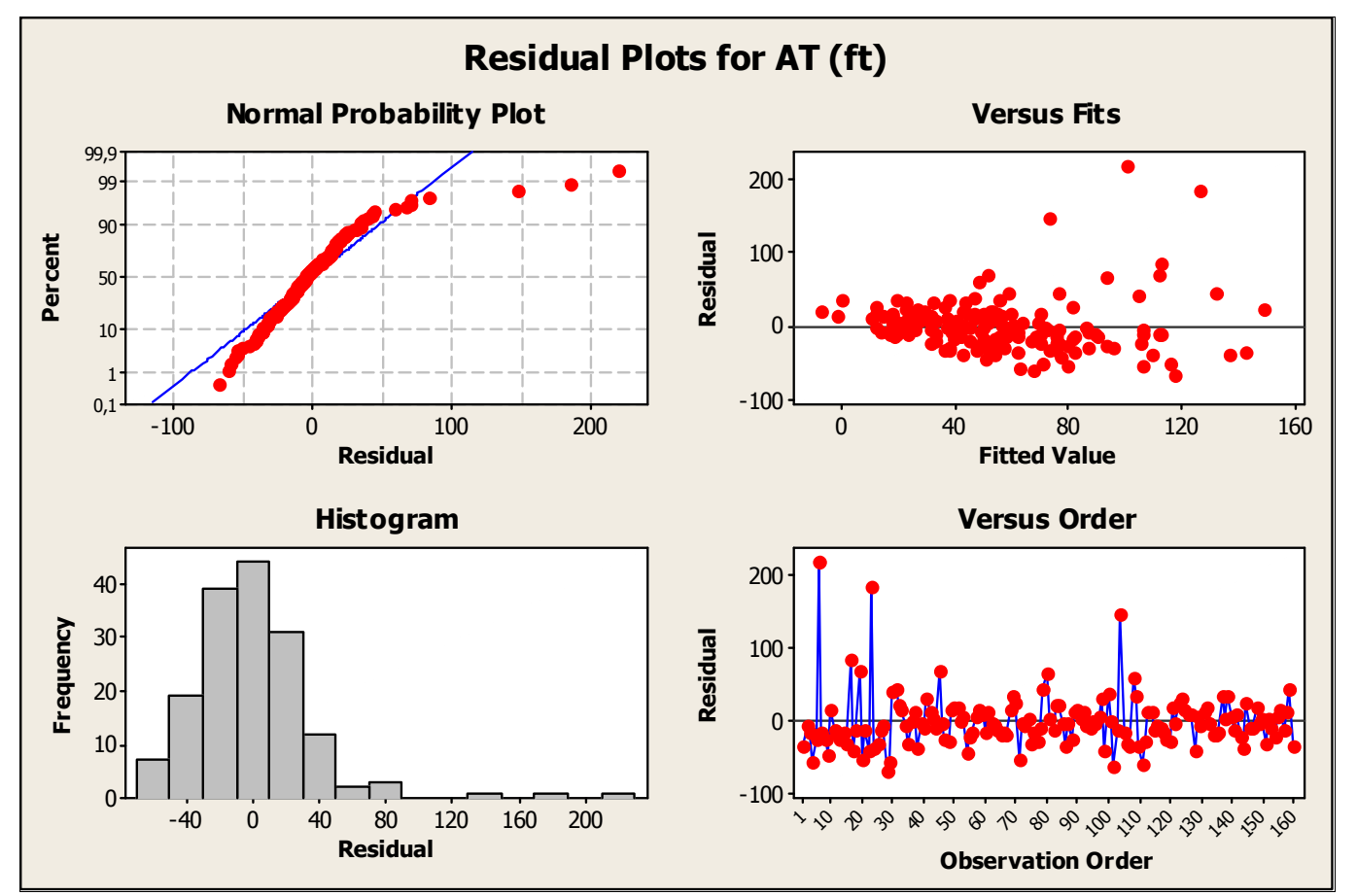

Figure 54 Hover: Residuals Plot for AT (4 Object Density *4 Object Size)

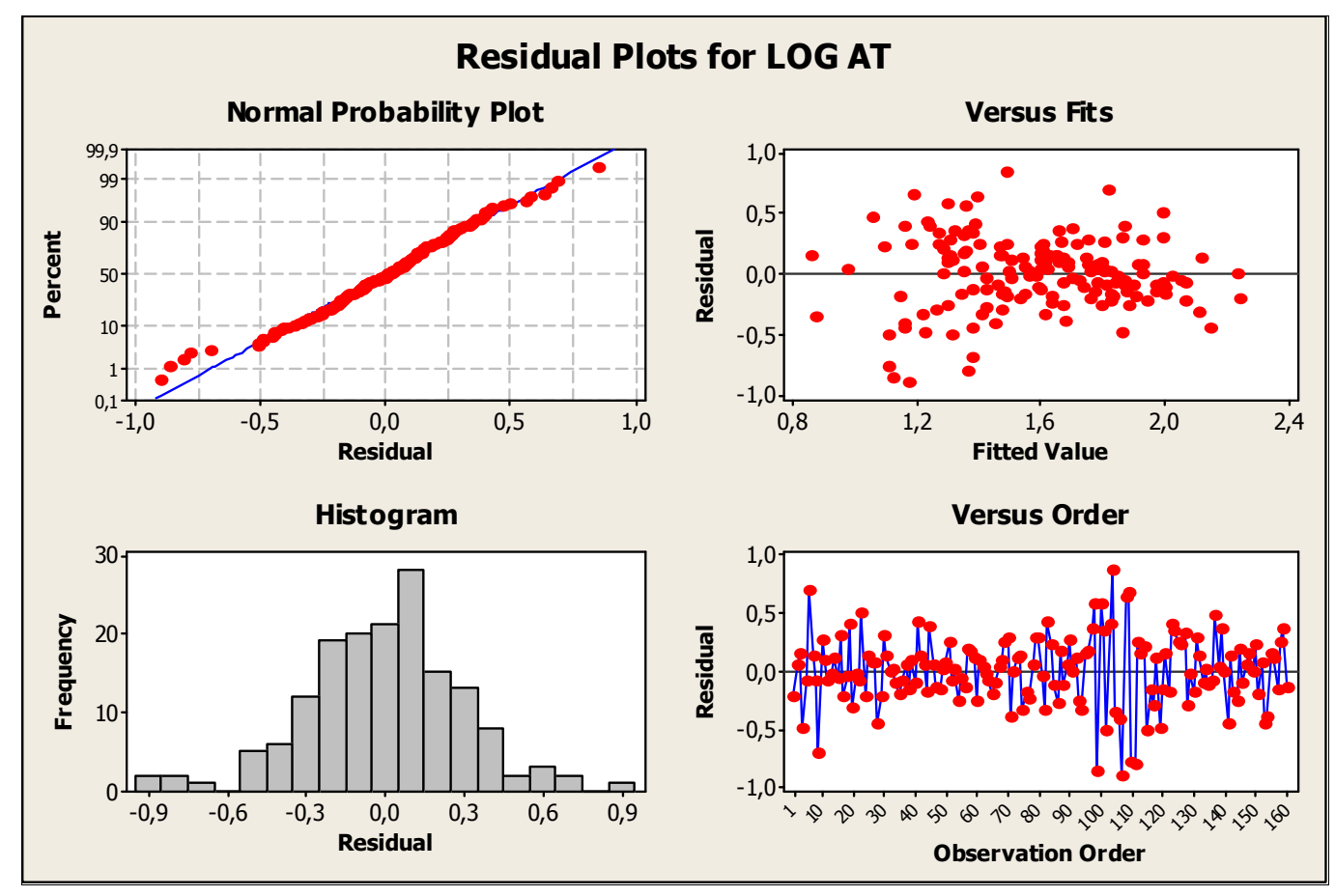

Figure 55 Hover: Residuals Plot for LOG AT (4 Object Density *4 Object Size) 


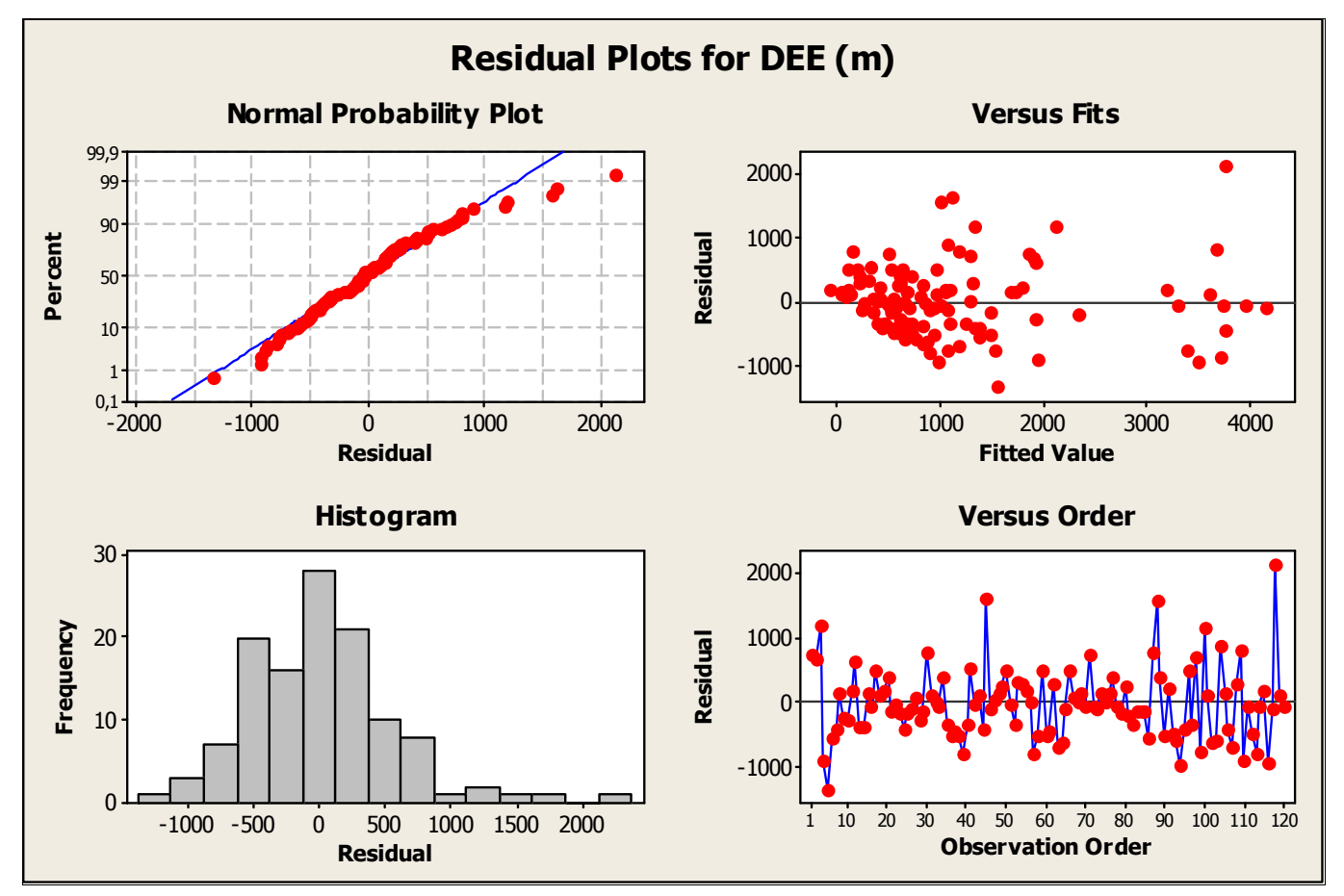

Figure 56 LAF: Residual Pilots for DEE (4 Object Density *3 Object Size)

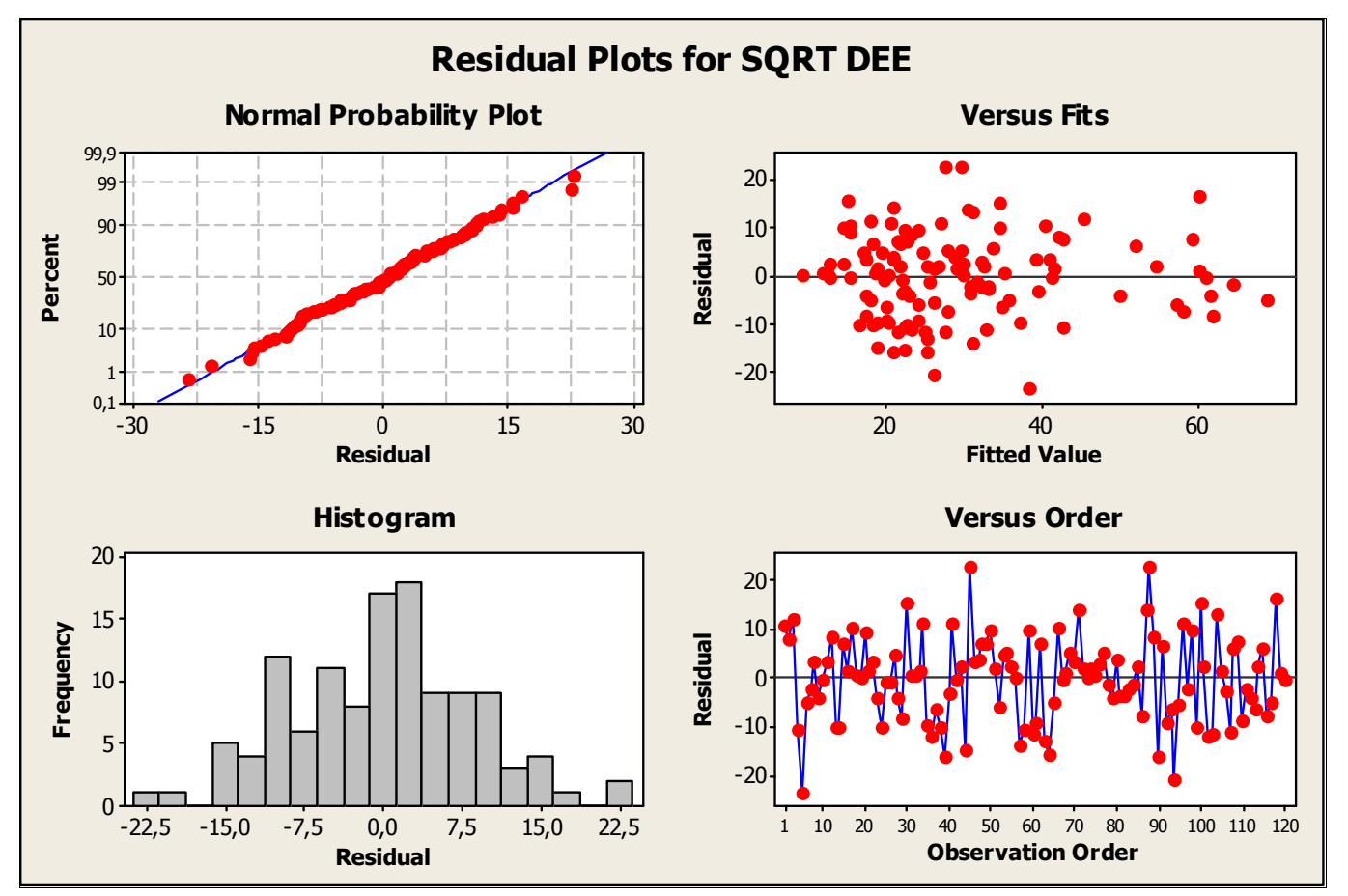

Figure 57 LAF: Residual Pilots for SQRT DEE (4 Object Density *3 Object Size) 


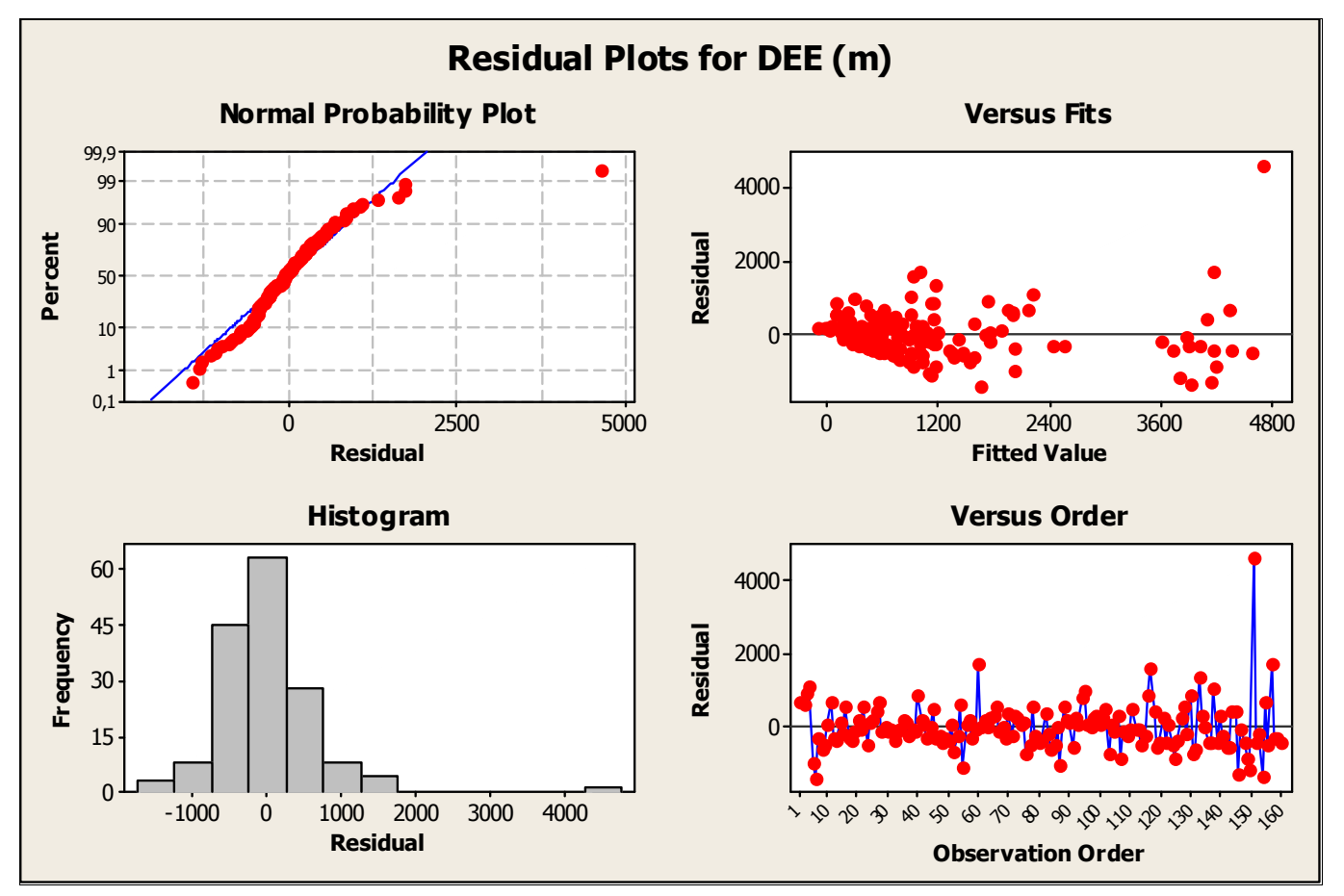

Figure 58 LAF: Residuals Plot for DEE (4 Object Density *4 Object Size)

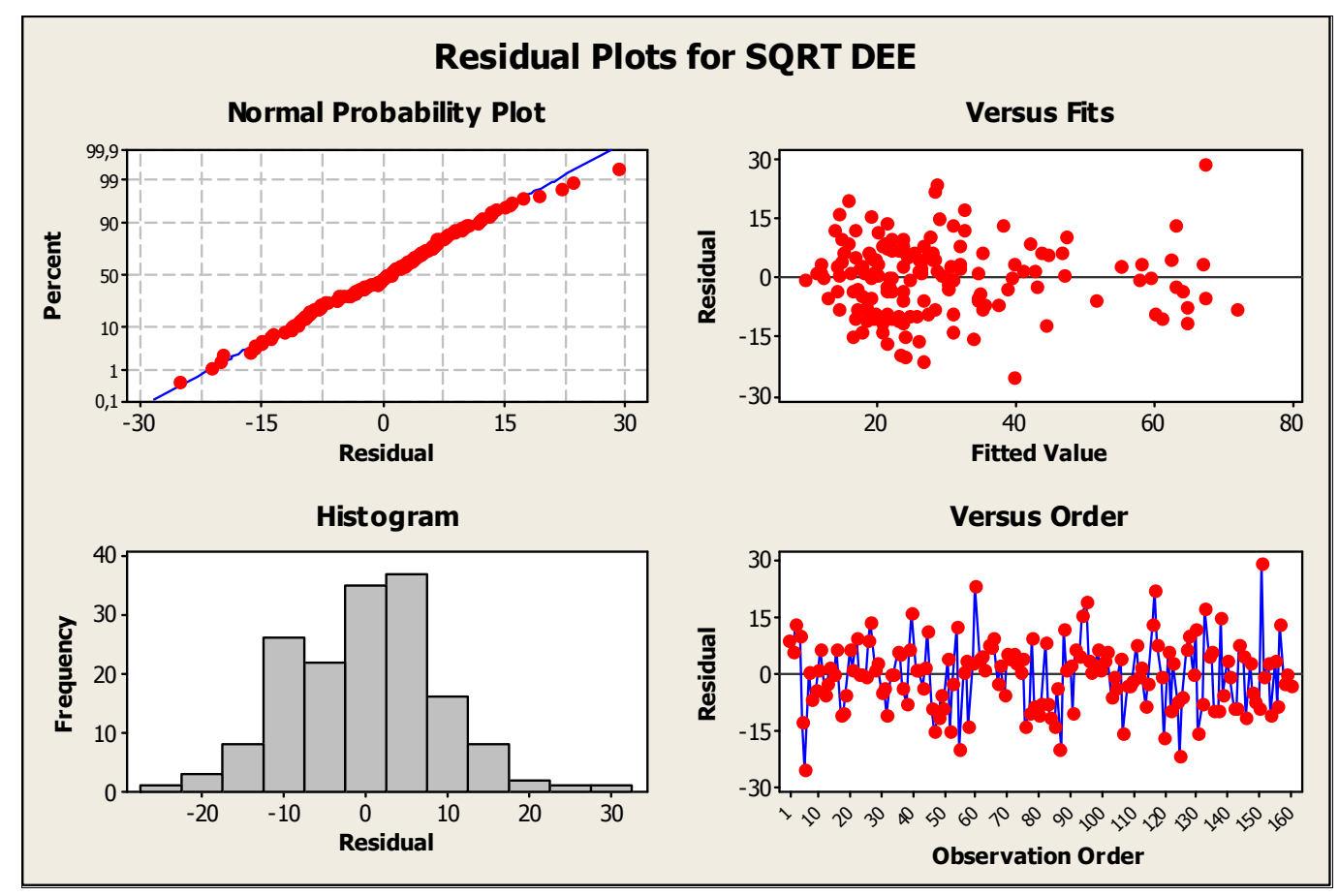

Figure 59 LAF: Residuals Plot for SQRT DEE (4 Object Density *4 Object Size) 


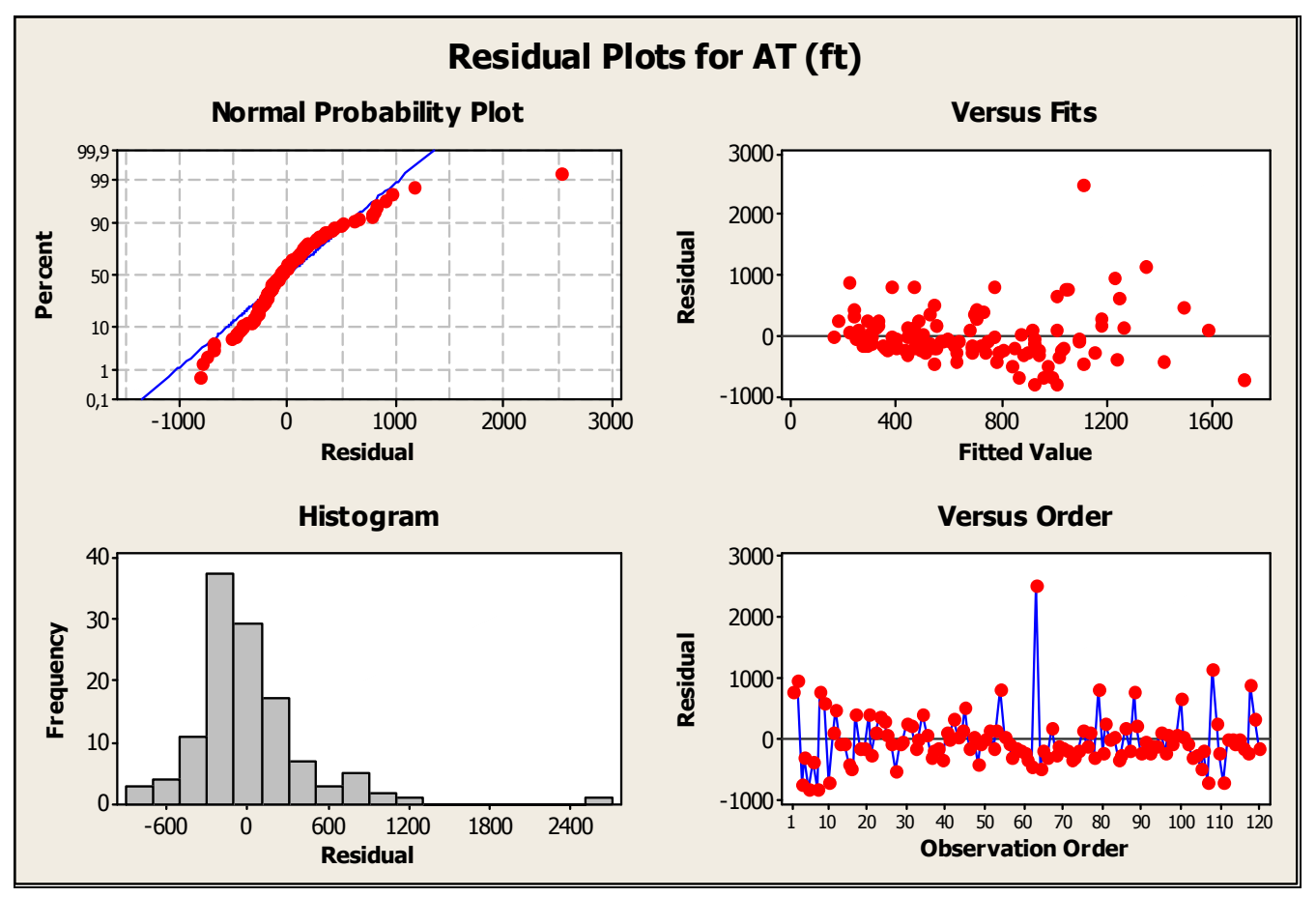

Figure 60 LAF: Residuals Plot for AT (4 Object Density *3 Object Size)

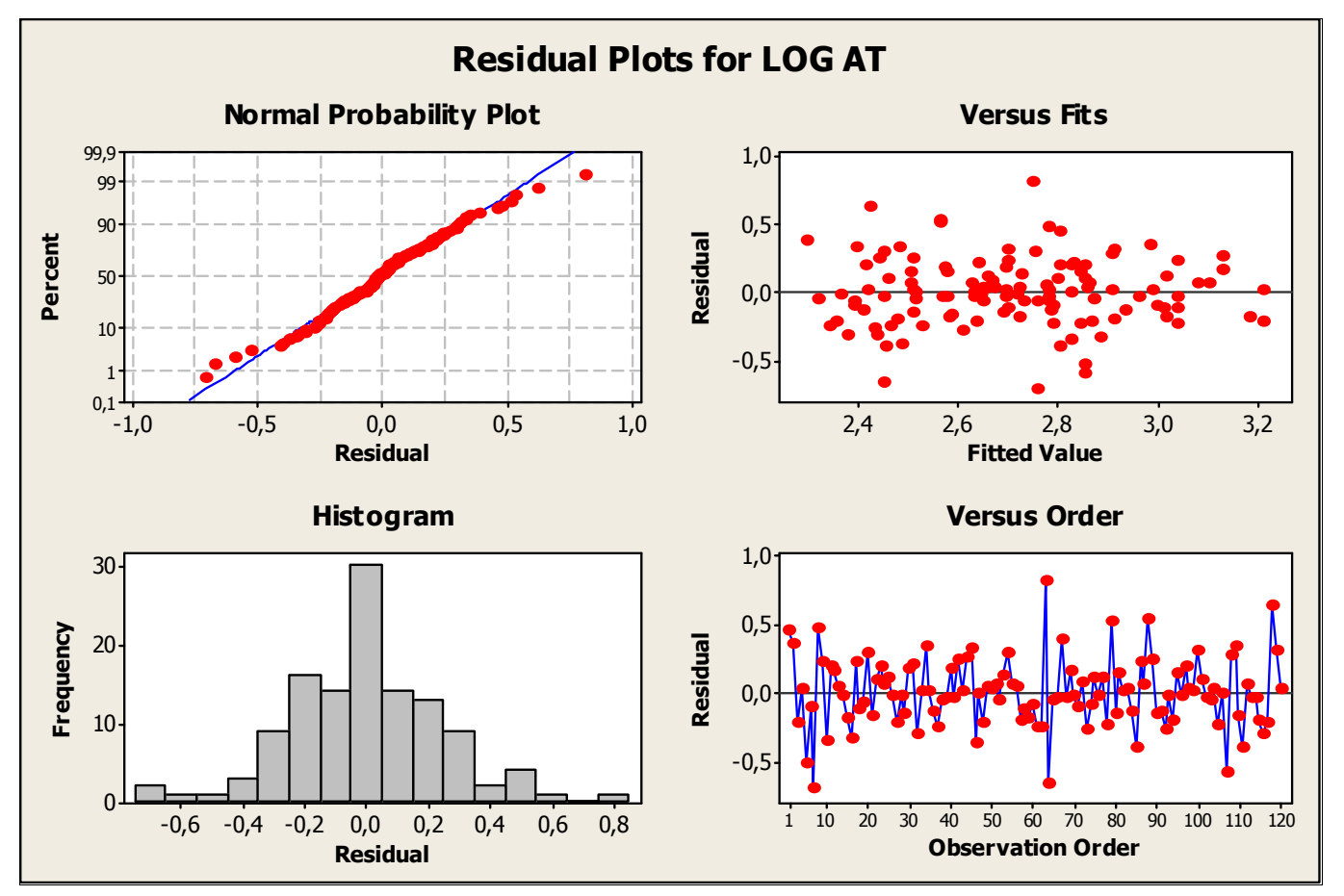

Figure 61 LAF: Residuals Plot for LOG AT (4 Object Density *3 Object Size) 


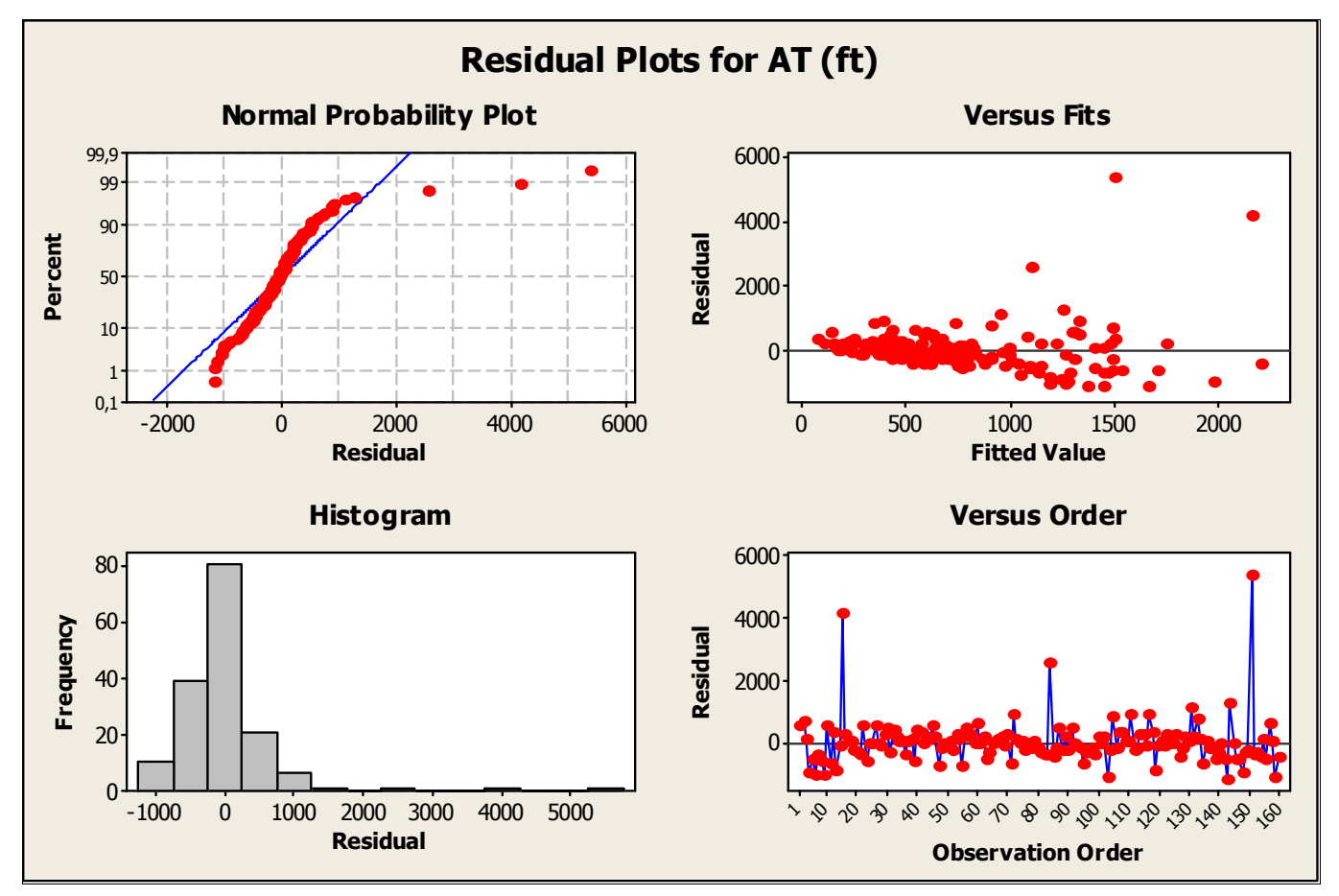

Figure 62 LAF: Residuals Plot for AT (4 Object Density *4 Object Size)

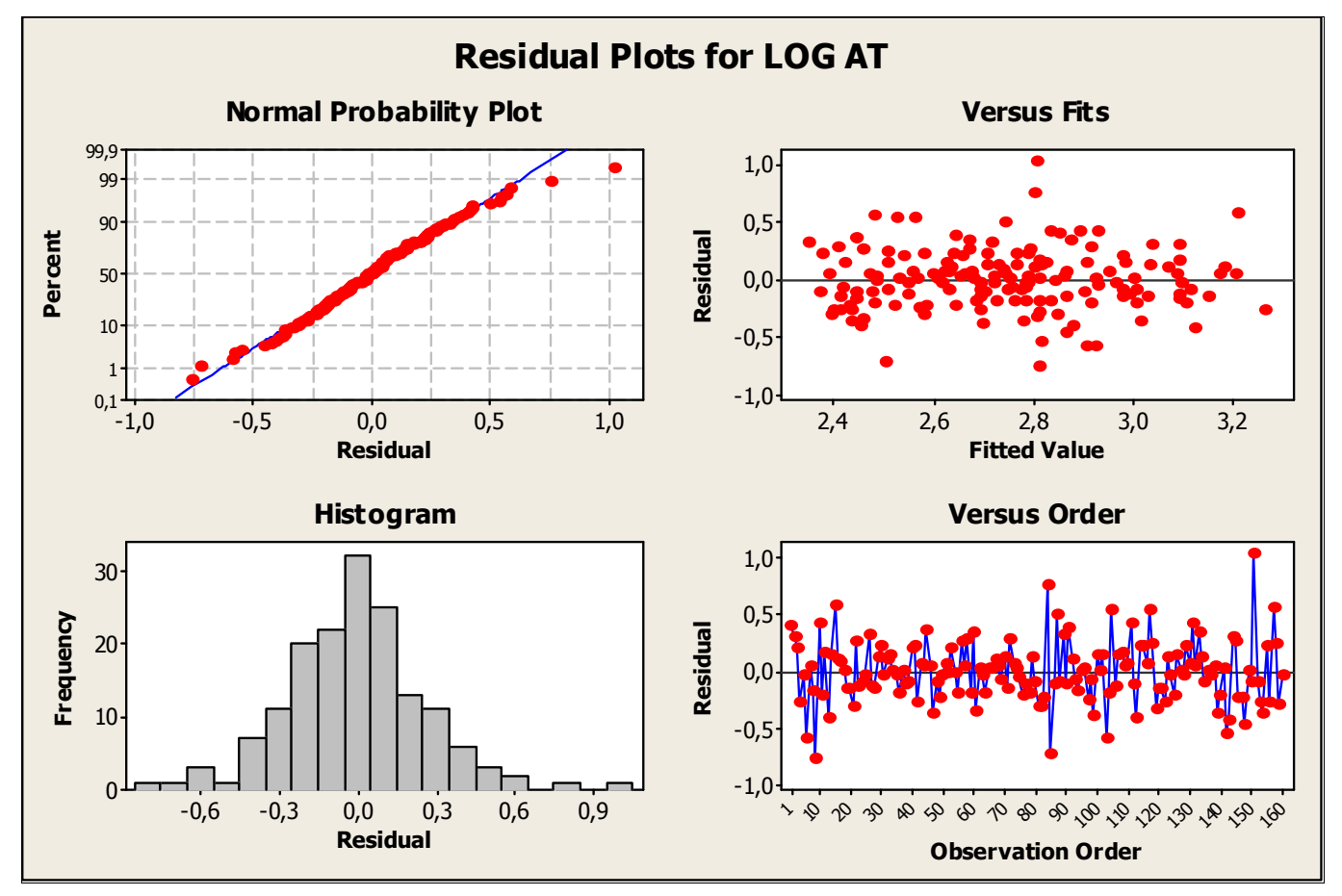


Figure 63 LAF: Residuals Plot for LOG AT (4 Object Density *4 Object Size)

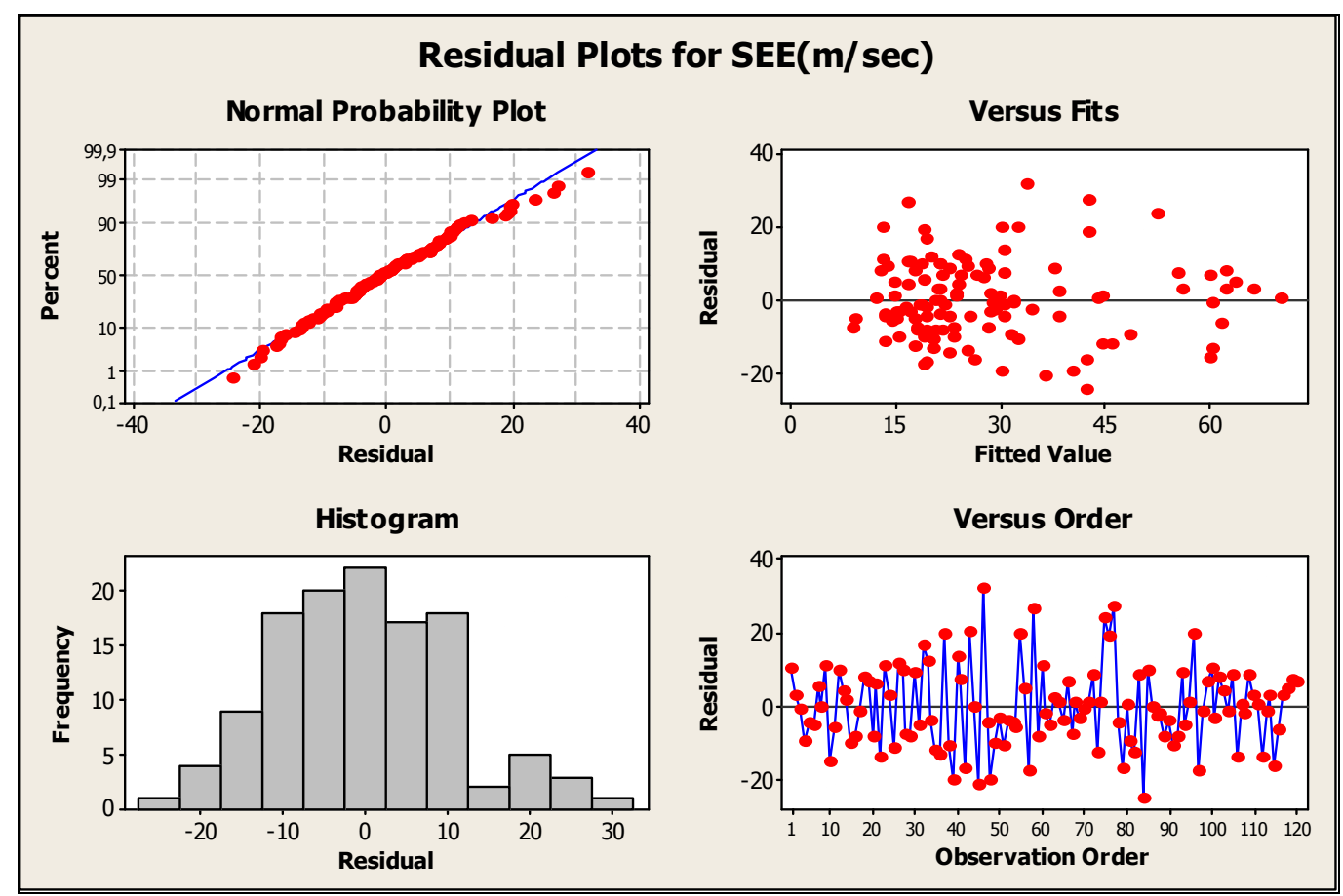

Figure 64 LAF: Residuals Plot for SEE (4 Object Density *3 Object Size)

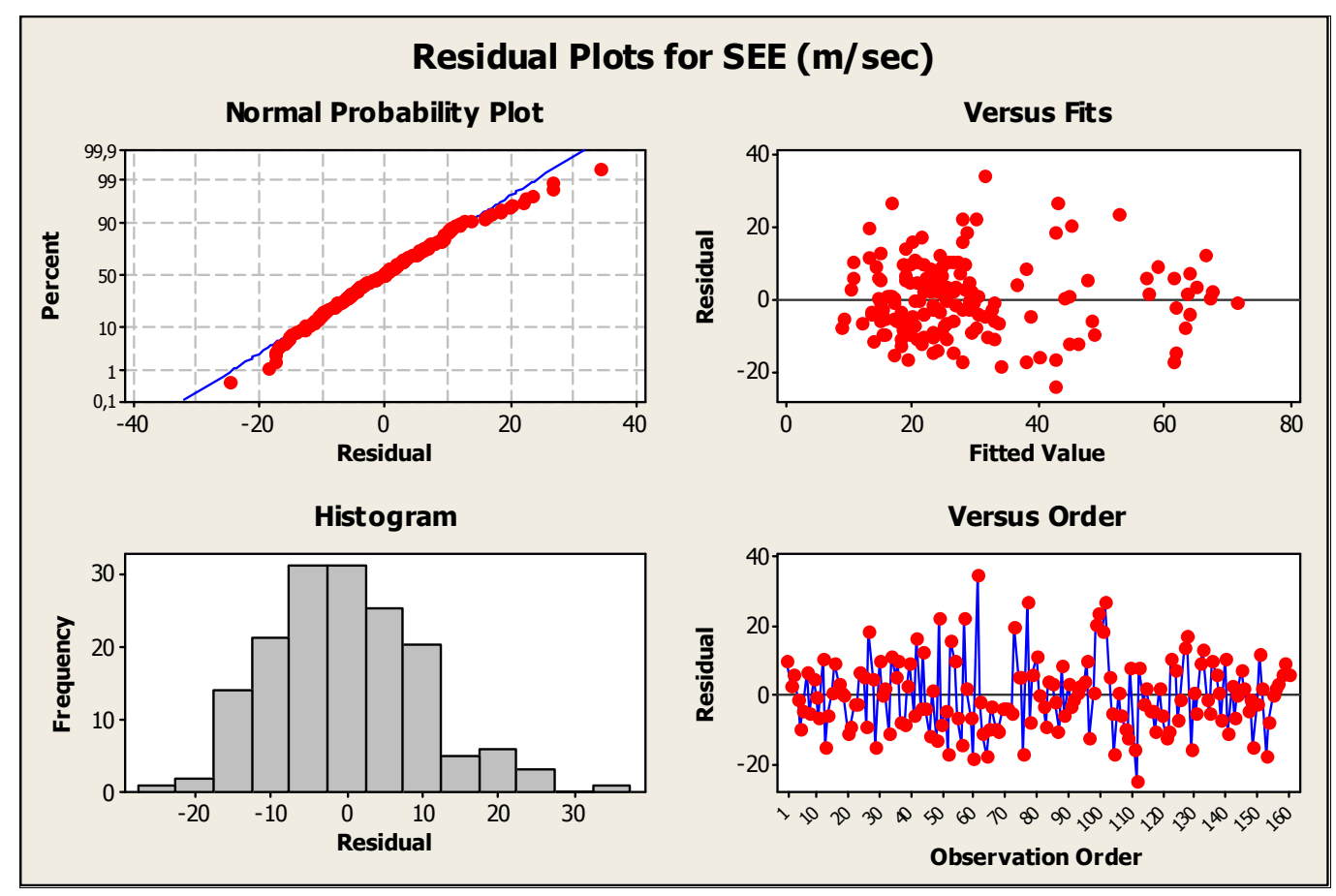

Figure 65 LAF: Residuals Plot for SEE (4 Object Density *4 Object Size) 


\section{APPENDIX G: ANOVA TABLES}

Table 14 Hover: ANOVA of DT vs. Run Order General Linear Model: DT versus run order; block Factor Type Levels Values

run order fixed $161 ; 2 ; 3 ; 4 ; 5 ; 6 ; 7 ; 8 ; 9 ; 10 ; 11 ; 12 ; 13 ; 14 ; 15 ; 16$

block fixed $101 ; 2 ; 3 ; 4 ; 5 ; 6 ; 7 ; 8 ; 9 ; 10$

Analysis of Variance for DT, using Adjusted SS for Tests

$\begin{array}{lrrrrrr}\text { Source } & \text { DF } & \text { Seq SS } & \text { Adj SS } & \text { Adj MS } & \text { F } & \text { P } \\ \text { run order } & 15 & 5873936 & 5873936 & 391596 & 0.94 & 0.526 \\ \text { block } & 9 & 28939043 & 28939043 & 3215449 & 7.69 & 0.000 \\ \text { Error } & 135 & 56473336 & 56473336 & 418321 & & \\ \text { Total } & 159 & 91286315 & & & & \end{array}$

Table 15 Hover: ANOVA of AT vs. Run Order

General Linear Model: AT versus run order; block

Factor Type Levels Values

run order fixed $161 ; 2 ; 3 ; 4 ; 5 ; 6 ; 7 ; 8 ; 9 ; 10 ; 11 ; 12 ; 13 ; 14 ; 15 ; 16$

block fixed $101 ; 2 ; 3 ; 4 ; 5 ; 6 ; 7 ; 8 ; 9 ; 10$

Analysis of Variance for AT, using Adjusted SS for Tests

$\begin{array}{lrrrrrr}\text { Source } & \text { DF } & \text { Seq SS } & \text { Adj SS } & \text { Adj MS } & \text { F } & \text { P } \\ \text { run order } & 15 & 28690 & 28690 & 1913 & 1.12 & 0.341 \\ \text { block } & 9 & 116684 & 116684 & 12965 & 7.62 & 0.000 \\ \text { Error } & 135 & 229617 & 229617 & 1701 & & \\ \text { Total } & 159 & 374991 & & & & \end{array}$

Table 16 Hover: ANOVA of LOG DT vs. Object Density, Object Size, Block No (Subject) (Without Mixture)

General Linear Model: LOG DT versus Blocks; density; height

Factor Type Levels Values

Blocks fixed $101 ; 2 ; 3 ; 4 ; 5 ; 6 ; 7 ; 8 ; 9 ; 10$

density fixed $436 ; 144 ; 576 ; 1296$

height fixed $32 ; 5 ; 10$

Analysis of Variance for LOG DT, using Adjusted SS for Tests

$\begin{array}{lrrrrrr}\text { Source } & \text { DF } & \text { Seq SS } & \text { Adj SS } & \text { Adj MS } & \text { F } & \text { P } \\ \text { Blocks } & 9 & 2,34548 & 2,34548 & 0,26061 & 11,37 & 0,000 \\ \text { density } & 3 & 0,22074 & 0,22074 & 0,07358 & 3,21 & 0,026 \\ \text { height } & 2 & 0,14403 & 0,14403 & 0,07202 & 3,14 & 0,047 \\ \text { density*height } & 6 & 0,03944 & 0,03944 & 0,00657 & 0,29 & 0,942 \\ \text { Error } & 99 & 2,26843 & 2,26843 & 0,02291 & & \\ \text { Total } & 119 & 5,01812 & & & & \end{array}$


Table 17 Hover: ANOVA of LOG DT vs. Object Density, Object Size, Block No (Subject) (With Mixture)

General Linear Model: LOG DT versus Blocks; density; height

Factor Type Levels Values

Blocks fixed $101 ; 2 ; 3 ; 4 ; 5 ; 6 ; 7 ; 8 ; 9 ; 10$

density fixed $436 ; 144 ; 576 ; 1296$

height fixed 4 2; 5; mixture; 10

Analysis of Variance for LOG DT, using Adjusted SS for Tests

$\begin{array}{lrrrrrr}\text { Source } & \text { DF } & \text { Seq SS } & \text { Adj SS } & \text { Adj MS } & \text { F } & \text { P } \\ \text { Blocks } & 9 & 2,99612 & 2,99612 & 0,33290 & 10,21 & 0,000 \\ \text { density } & 3 & 0,17723 & 0,17723 & 0,05908 & 1,81 & 0,148 \\ \text { height } & 3 & 0,19649 & 0,19649 & 0,06550 & 2,01 & 0,116 \\ \text { density*height } & 9 & 0,18032 & 0,18032 & 0,02004 & 0,61 & 0,783 \\ \text { Error } & 135 & 4,40123 & 4,40123 & 0,03260 & & \\ \text { Total } & 159 & 7,95139 & & & & \end{array}$

Table 18 Hover: ANOVA of LOG AT vs. Object Density, Object Size, Block No (Subject) Without Mixture)

General Linear Model: LOG AT versus Blocks; density; height

Factor Type Levels Values

Blocks fixed $101 ; 2 ; 3 ; 4 ; 5 ; 6 ; 7 ; 8 ; 9 ; 10$

density fixed $436 ; 144 ; 576 ; 1296$

height fixed $42 ; 5 ; 10$

Analysis of Variance for LOG AT, using Adjusted SS for Tests

$\begin{array}{lrrrrrr}\text { Source } & \text { DF } & \text { Seq SS } & \text { Adj SS } & \text { Adj MS } & \text { F } & P \\ \text { Blocks } & 9 & 5,39968 & 5,39968 & 0,59996 & 6,91 & 0,000 \\ \text { density } & 3 & 0,81087 & 0,81087 & 0,27029 & 3,11 & 0,030 \\ \text { height } & 2 & 1,60129 & 1,60129 & 0,80065 & 9,22 & 0,000 \\ \text { density*height } & 6 & 0,84588 & 0,84588 & 0,14098 & 1,62 & 0,148 \\ \text { Error } & 99 & 8,59367 & 8,59367 & 0,08680 & & \\ \text { Total } & 119 & 17,25139 & & & & \end{array}$

Table 19 Hover: ANOVA of LOG AT vs. Object Density, Object Size, Block No (Subject) (With Mixture)

General Linear Model: LOG AT versus Blocks; density; height

Factor Type Levels Values

Blocks fixed $101 ; 2 ; 3 ; 4 ; 5 ; 6 ; 7 ; 8 ; 9 ; 10$

density fixed $436 ; 144 ; 576 ; 1296$

height fixed 4 2; 5 ; mixture; 10

Analysis of Variance for LOG AT, using Adjusted SS for Tests

$\begin{array}{lrrrrrr}\text { Source } & \text { DF } & \text { Seq SS } & \text { Adj SS } & \text { Adj MS } & \text { F } & \text { P } \\ \text { Blocks } & 9 & 9,2363 & 9,2363 & 1,0263 & 9,94 & 0,000 \\ \text { density } & 3 & 0,7058 & 0,7058 & 0,2353 & 2,28 & 0,082 \\ \text { height } & 3 & 1,6684 & 1,6684 & 0,5561 & 5,39 & 0,002 \\ \text { density*height } & 9 & 1,2807 & 1,2807 & 0,1423 & 1,38 & 0,204 \\ \text { Error } & 135 & 13,9401 & 13,9401 & 0,1033 & & \\ \text { Total } & 159 & 26,8314 & & & \end{array}$


Table 20 LAF: ANOVA of SEE vs. Run Order General Linear Model: SEE versus run order; block Factor Type Levels Values

run order fixed $161 ; 2 ; 3 ; 4 ; 5 ; 6 ; 7 ; 8 ; 9 ; 10 ; 11 ; 12 ; 13 ; 14 ; 15 ; 16$

block fixed $101 ; 2 ; 3 ; 4 ; 5 ; 6 ; 7 ; 8 ; 9 ; 10$

Analysis of Variance for SEE, using Adjusted SS for Tests

$\begin{array}{lrrrrrr}\text { Source } & \text { DF } & \text { Seq SS } & \text { Adj SS } & \text { Adj MS } & \text { F } & \text { P } \\ \text { run order } & 15 & 2019,3 & 2019,3 & 134,6 & 1,07 & 0,391 \\ \text { block } & 9 & 31324,1 & 31324,1 & 3480,5 & 27,63 & 0,000 \\ \text { Error } & 135 & 17003,0 & 17003,0 & 125,9 & & \\ \text { Total } & 159 & 50346,4 & & & & \end{array}$

Table 21 LAF: ANOVA of DEE vs. Run Order General Linear Model: DEE versus run order; block

Factor Type Levels Values

run order fixed $161 ; 2 ; 3 ; 4 ; 5 ; 6 ; 7 ; 8 ; 9 ; 10 ; 11 ; 12 ; 13 ; 14 ; 15 ; 16$

block fixed $101 ; 2 ; 3 ; 4 ; 5 ; 6 ; 7 ; 8 ; 9 ; 10$

Analysis of Variance for DEE, using Adjusted SS for Tests

$\begin{array}{lrrrrrr}\text { Source } & \text { DF } & \text { Seq SS } & \text { Adj SS } & \text { Adj MS } & \text { F } & \text { P } \\ \text { run order } & 15 & 7757918 & 7757918 & 517195 & 0,93 & 0,530 \\ \text { block } & 9 & 187423096 & 187423096 & 20824788 & 37,57 & 0,000 \\ \text { Error } & 135 & 74827967 & 74827967 & 554281 & & \\ \text { Total } & 159 & 270008981 & & & & \end{array}$

Table 22 LAF: ANOVA of AT vs. Run Order

General Linear Model: AT versus run order; block

Factor Type Levels Values

run order fixed $161 ; 2 ; 3 ; 4 ; 5 ; 6 ; 7 ; 8 ; 9 ; 10 ; 11 ; 12 ; 13 ; 14 ; 15 ; 16$

block fixed $101 ; 2 ; 3 ; 4 ; 5 ; 6 ; 7 ; 8 ; 9 ; 10$

Analysis of Variance for AT, using Adjusted SS for Tests

$\begin{array}{lrrrrrr}\text { Source } & \text { DF } & \text { Seq SS } & \text { Adj SS } & \text { Adj MS } & \text { F } & \text { P } \\ \text { run order } & 15 & 17193687 & 17193687 & 1146246 & 1,87 & 0,031 \\ \text { block } & 9 & 15523608 & 15523608 & 1724845 & 2,81 & 0,005 \\ \text { Error } & 135 & 82724011 & 82724011 & 612770 & & \\ \text { Total } & 159 & 115441306 & & & & \end{array}$

Table 23 LAF: Two-way ANOVA: AT versus run order; block (without first run)

$\begin{array}{lrrrrr}\text { Source } & \text { DF } & \text { SS } & \text { MS } & F & P \\ \text { run order } & 14 & 10455396 & 746814 & 2,13 & 0,014 \\ \text { block } & 9 & 19246950 & 2138550 & 6,11 & 0,000 \\ \text { Error } & 126 & 44088696 & 349910 & & \\ \text { Total } & 149 & 73791041 & & & \\ S=591,5 & R-S q=40,25 \% & R-S q(\text { adj })=29,35 \%\end{array}$


Table 24 LAF: ANOVA of SQRT DEE vs. Object Density, Object Size, Block No (Subject) (Without Mixture)

General Linear Model: SQRT DEE versus Blocks; density; height

Factor Type Levels Values

Blocks fixed $101 ; 2 ; 3 ; 4 ; 5 ; 6 ; 7 ; 8 ; 9 ; 10$

density fixed $436 ; 144 ; 576 ; 1296$

height fixed $32 ; 5 ; 10$

Analysis of Variance for SQRT DEE, using Adjusted SS for Tests

$\begin{array}{lrrrrrr}\text { Source } & \text { DF } & \text { Seq SS } & \text { Adj SS } & \text { Adj MS } & \text { F } & \text { P } \\ \text { Blocks } & 9 & 18374,9 & 18374,9 & 2041,7 & 22,40 & 0,000 \\ \text { density } & 3 & 243,2 & 243,2 & 81,1 & 0,89 & 0,450 \\ \text { height } & 2 & 333,4 & 333,4 & 166,7 & 1,83 & 0,166 \\ \text { density*height } & 6 & 1483,3 & 1483,3 & 247,2 & 2,71 & 0,018 \\ \text { Error } & 99 & 9024,5 & 9024,5 & 91,2 & & \\ \text { Total } & 119 & 29459,4 & & & \end{array}$

Table 25 LAF: ANOVA of SQRT DEE vs. Object Density, Object Size, Block No (Subject) (With Mixture)

General Linear Model: SQRT DEE versus Blocks; density; height

Factor Type Levels Values

Blocks fixed $101 ; 2 ; 3 ; 4 ; 5 ; 6 ; 7 ; 8 ; 9 ; 10$

density fixed $436 ; 144 ; 576 ; 1296$

height fixed $42 ; 5 ; \mathrm{mix} ; 10$

Analysis of Variance for SQRT DEE, using Adjusted SS for Tests

$\begin{array}{lrrrrrr}\text { Source } & \text { DF } & \text { Seq SS } & \text { Adj SS } & \text { Adj MS } & F & P \\ \text { Blocks } & 9 & 28860,7 & 28860,7 & 3206,7 & 32,64 & 0,000 \\ \text { density } & 3 & 47,5 & 47,5 & 15,8 & 0,16 & 0,922 \\ \text { height } & 3 & 333,5 & 333,5 & 111,2 & 1,13 & 0,339 \\ \text { density*height } & 9 & 2365,2 & 2365,2 & 262,8 & 2,67 & 0,007 \\ \text { Error } & 135 & 13263,7 & 13263,7 & 98,2 & & \\ \text { Total } & 159 & 44870,5 & & & & \end{array}$

Table 26 LAF: ANOVA of LOG AT vs. Object Density, Object Size, Block No (Subject)

(Without Mixture)

General Linear Model: LOG AT versus run order; block

Factor Type Levels Values

Blocks fixed $101 ; 2 ; 3 ; 4 ; 5 ; 6 ; 7 ; 8 ; 9 ; 10$

density fixed $436 ; 144 ; 576 ; 1296$

height fixed $42 ; 5 ; 10$

Analysis of Variance for LOG AT, using Adjusted SS for Tests

$\begin{array}{lrrrrrr}\text { Source } & \text { DF } & \text { Seq SS } & \text { Adj SS } & \text { Adj MS } & \text { F } & P \\ \text { Blocks } & 9 & 3,40759 & 3,40759 & 0,37862 & 5,07 & 0,000 \\ \text { density } & 3 & 0,29839 & 0,29839 & 0,09946 & 1,33 & 0,268 \\ \text { height } & 2 & 1,82446 & 1,82446 & 0,91223 & 12,22 & 0,000 \\ \text { density*height } & 6 & 0,25499 & 0,25499 & 0,04250 & 0,57 & 0,754 \\ \text { Error } & 99 & 7,38962 & 7,38962 & 0,07464 & & \\ \text { Total } & 119 & 13,17504 & & & & \end{array}$


Table 27 LAF: ANOVA of LOG AT vs. Object Density, Object Size, Block No (Subject) (With Mixture)

General Linear Model: LOG AT versus run order; block

Factor Type Levels Values

Blocks fixed $101 ; 2 ; 3 ; 4 ; 5 ; 6 ; 7 ; 8 ; 9 ; 10$

density fixed $436 ; 144 ; 576 ; 1296$

height fixed 4 2; 5; mixture; 10

Analysis of Variance for LOG AT, using Adjusted SS for Tests

$\begin{array}{lrrrrrr}\text { Source } & \text { DF } & \text { Seq SS } & \text { Adj SS } & \text { Adj MS } & \text { F } & \text { P } \\ \text { Blocks } & 9 & 4,09187 & 4,09187 & 0,45465 & 5,38 & 0,000 \\ \text { density } & 3 & 0,19309 & 0,19309 & 0,06436 & 0,76 & 0,518 \\ \text { height } & 3 & 2,41912 & 2,41912 & 0,80637 & 9,54 & 0,000 \\ \text { density*height } & 9 & 0,71061 & 0,71061 & 0,07896 & 0,93 & 0,498 \\ \text { Error } & 135 & 11,41434 & 11,41434 & 0,08455 & & \\ \text { Total } & 159 & 18,82904 & & & & \end{array}$

Table 28 LAF: ANOVA of SEE vs. Object Density, Object Size, Block No (Subject) (Without Mixture)

General Linear Model: SEE versus run order; block

Factor Type Levels Values

Blocks fixed $101 ; 2 ; 3 ; 4 ; 5 ; 6 ; 7 ; 8 ; 9 ; 10$

density fixed $436 ; 144 ; 576 ; 1296$

height fixed $42 ; 5 ; 10$

Analysis of Variance for SEE, using Adjusted SS for Tests

$\begin{array}{lrrrrrr}\text { Source } & \text { DF } & \text { Seq SS } & \text { Adj SS } & \text { Adj MS } & \text { F } & \text { P } \\ \text { Blocks } & 9 & 22484,7 & 22484,7 & 2498,3 & 17,73 & 0,000 \\ \text { density } & 3 & 685,3 & 685,3 & 228,4 & 1,62 & 0,189 \\ \text { height } & 2 & 194,7 & 194,7 & 97,3 & 0,69 & 0,504 \\ \text { density*height } & 6 & 860,1 & 860,1 & 143,3 & 1,02 & 0,419 \\ \text { Error } & 99 & 13953,7 & 13953,7 & 140,9 & & \\ \text { Total } & 119 & 38178,4 & & & \end{array}$

Table 29 LAF: ANOVA of SEE vs. Object Density, Object Size, Block No (Subject) (With Mixture)

General Linear Model: SEE versus run order; block

Factor Type Levels Values

Blocks fixed $101 ; 2 ; 3 ; 4 ; 5 ; 6 ; 7 ; 8 ; 9 ; 10$

density fixed $436 ; 144 ; 576 ; 1296$

height fixed 4 2; 5; mixture; 10

Analysis of Variance for SEE, using Adjusted SS for Tests

$\begin{array}{lrrrrrr}\text { Source } & \text { DF } & \text { Seq SS } & \text { Adj SS } & \text { Adj MS } & \text { F } & \text { P } \\ \text { Blocks } & 9 & 31324,1 & 31324,1 & 3480,5 & 27,94 & 0,000 \\ \text { density } & 3 & 708,4 & 708,4 & 236,1 & 1,90 & 0,133 \\ \text { height } & 3 & 242,6 & 242,6 & 80,9 & 0,65 & 0,585 \\ \text { density*height } & 9 & 1256,4 & 1256,4 & 139,6 & 1,12 & 0,352 \\ \text { Error } & 135 & 16814,9 & 16814,9 & 124,6 & & \\ \text { Total } & 159 & 50346,4 & & & \end{array}$


Table 30 Hover: ANOVA of SCORE vs. Object Density, Object Size, Block No (Subject) General Linear Model: SCORE versus Blocks; density; height

Factor Type Levels Values

Blocks fixed $101 ; 2 ; 3 ; 4 ; 5 ; 6 ; 7 ; 8 ; 9 ; 10$

density fixed $46 ; 144 ; 576 ; 1296$

height fixed 4 2; 5; mixture; 10

Analysis of Variance for SCORE, using Adjusted SS for Tests

$\begin{array}{lrrrrrr}\text { Source } & \text { DF } & \text { Seq SS } & \text { Adj SS } & \text { Adj MS } & \text { F } & \text { P } \\ \text { Blocks } & 9 & 93,7562 & 93,7562 & 10,4174 & 20,70 & 0,000 \\ \text { density } & 3 & 6,6188 & 6,6188 & 2,2063 & 4,38 & 0,006 \\ \text { height } & 3 & 14,1187 & 14,1187 & 4,7062 & 9,35 & 0,000 \\ \text { density*height } & 9 & 6,0063 & 6,0063 & 0,6674 & 1,33 & 0,229 \\ \text { Error } & 135 & 67,9437 & 67,9437 & 0,5033 & & \\ \text { Total } & 159 & 188,4437 & & & & \end{array}$

Table 31 LAF: ANOVA of SCORE vs. Object Density, Object Size, Block No (Subject) General Linear Model: SCORE versus Blocks; density; height

Factor Type Levels Values

Blocks fixed $101 ; 2 ; 3 ; 4 ; 5 ; 6 ; 7 ; 8 ; 9 ; 10$

density fixed $436 ; 144 ; 576 ; 1296$

height fixed 4 2; 5; mixture; 10

Analysis of Variance for SCORE, using Adjusted SS for Tests

$\begin{array}{lrrrrrr}\text { Source } & \text { DF } & \text { Seq SS } & \text { Adj SS } & \text { Adj MS } & \text { F } & \text { P } \\ \text { Blocks } & 9 & 84,3063 & 84,3062 & 9,3674 & 27,02 & 0,000 \\ \text { density } & 3 & 7,4687 & 7,4687 & 2,4896 & 7,18 & 0,000 \\ \text { height } & 3 & 16,2688 & 16,2688 & 5,4229 & 15,65 & 0,000 \\ \text { density*height } & 9 & 2,1562 & 2,1562 & 0,2396 & 0,69 & 0,716 \\ \text { Error } & 135 & 46,7938 & 46,7938 & 0,3466 & & \\ \text { Total } & 159 & 156,9938 & & & \end{array}$


APPENDIX H: SUMMARY of the ANOVA RESULTS

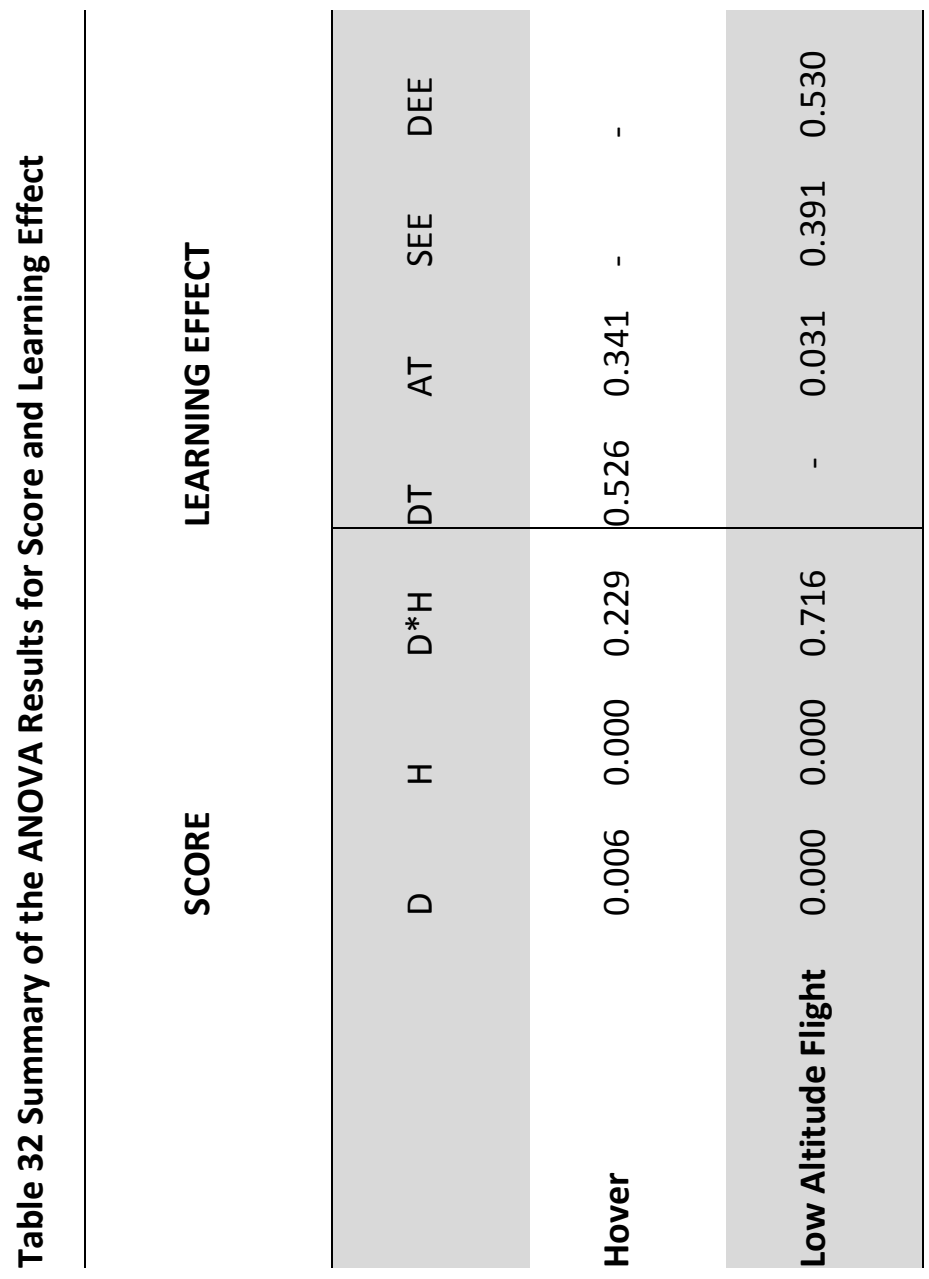




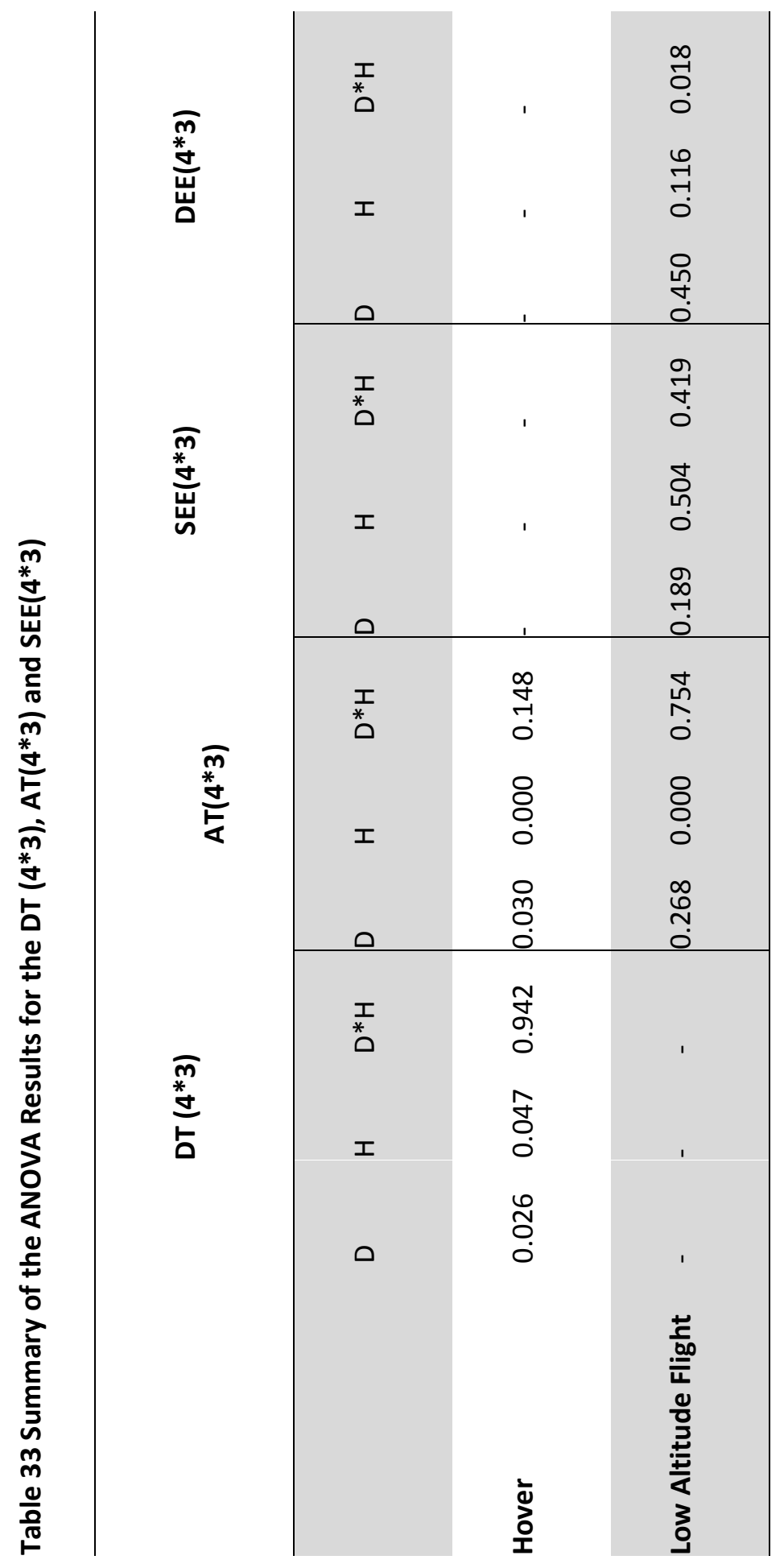




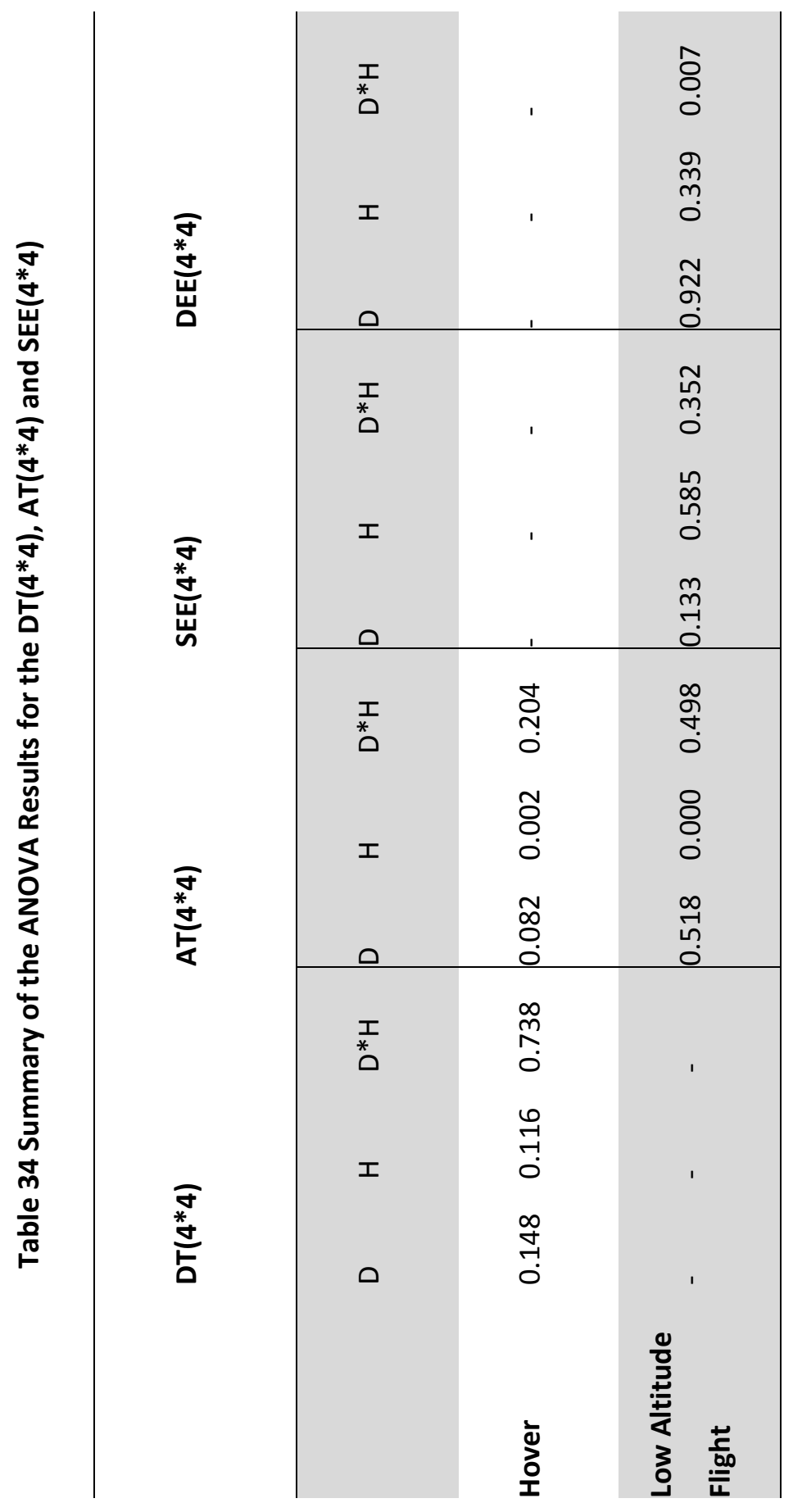

